\title{
Assessment of Water Quality and Discharge in the Herring River, Wellfleet, Massachusetts, November 2015 to September 2017
}

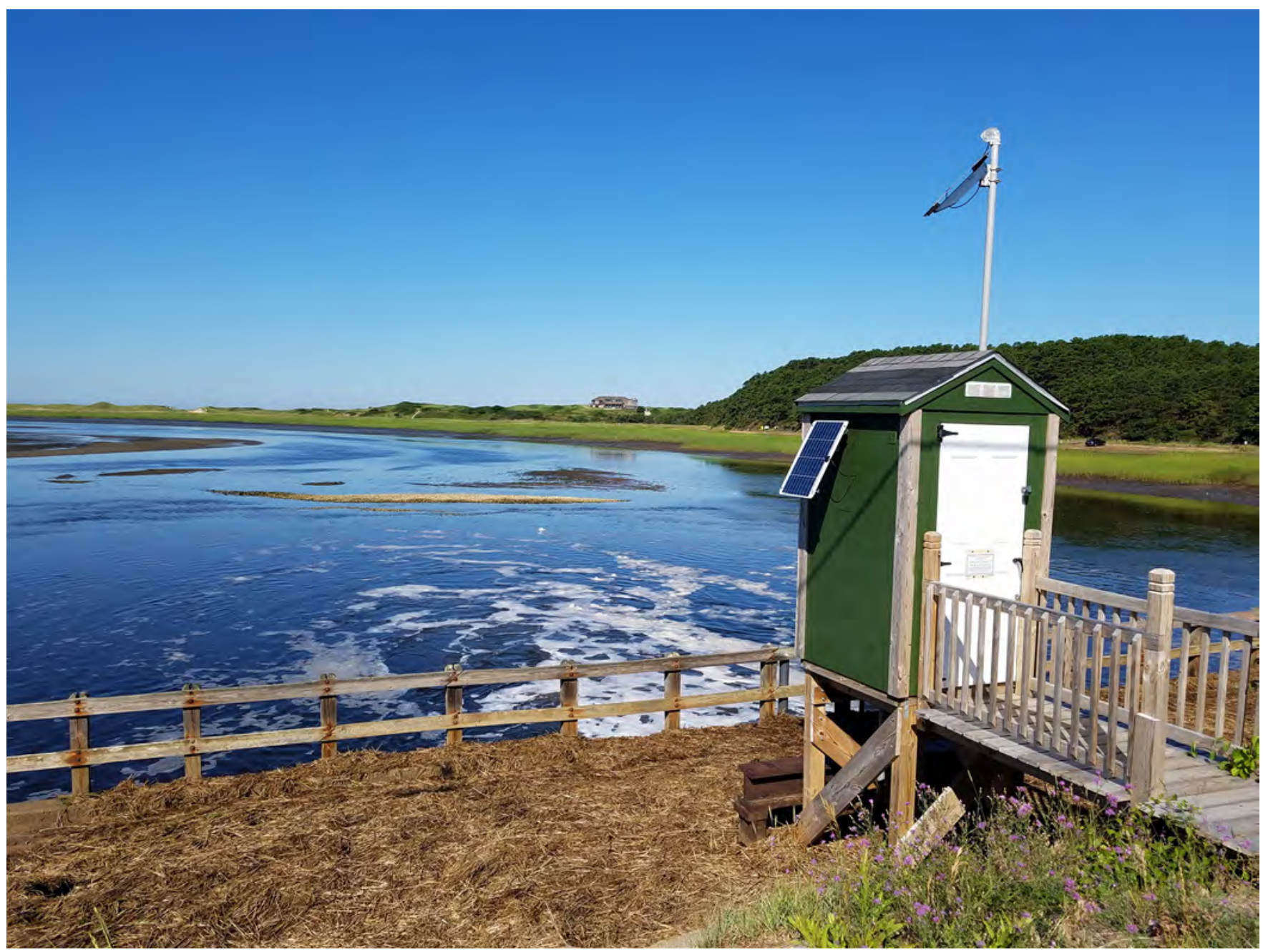

Scientific Investigations Report 2020-5120 
Cover. Front: U.S. Geological Survey (USGS) streamgage at the Herring River at Chequessett Neck Road at Wellfleet, Massachusetts (USGS station 011058798). Back: USGS hydrographer making a tethered boat acoustic Doppler current profiler discharge measurement at the Herring River at Chequessett Neck Road at Wellfleet, Mass. (USGS station 011058798). Photographs by the USGS. 


\section{Assessment of Water Quality and Discharge in the Herring River, Wellfleet, Massachusetts, November 2015 to September 2017}

By Thomas G. Huntington, Alana B. Spaetzel, John A. Colman, Kevin D. Kroeger, and Robert T. Bradley

Prepared in cooperation with the National Park Service and

Friends of Herring River

Scientific Investigations Report 2020-5120 


\section{U.S. Geological Survey, Reston, Virginia: 2021}

For more information on the USGS - the Federal source for science about the Earth, its natural and living resources, natural hazards, and the environment—visit https://www.usgs.gov or call 1-888-ASK-USGS.

For an overview of USGS information products, including maps, imagery, and publications, visit https://store.usgs.gov/.

Any use of trade, firm, or product names is for descriptive purposes only and does not imply endorsement by the U.S. Government.

Although this information product, for the most part, is in the public domain, it also may contain copyrighted materials as noted in the text. Permission to reproduce copyrighted items must be secured from the copyright owner.

Suggested citation:

Huntington, T.G., Spaetzel, A.B., Colman, J.A., Kroeger, K.D., and Bradley, R.T., 2021, Assessment of water quality and discharge in the Herring River, Wellfleet, Massachusetts, November 2015 to September 2017: U.S. Geological Survey Scientific Investigations Report 2020-5120, 59 p., https://doi.org/10.3133/sir20205120.

Associated data for this publication:

Huntington, T.G., and Spaetzel, A.B., 2020, Tidal daily discharge and quality assurance data supporting an assessment of water quality and discharge in the Herring River, Wellfleet, Massachusetts, November 2015-September 2017: U.S. Geological Survey data release, https://doi.org/10.5066/P9BKW4BX.

ISSN 2328-0328 (online 


\section{Acknowledgments}

The authors are grateful for the support they received from several people who contributed to the successful completion of this study. Timothy Smith at the Cape Cod National Seashore (National Park Service) provided logistical support.

U.S. Geological Survey personnel contributed to the study in several ways. Natasha Drotar provided support for field sample collection, processing, and sample analysis. Kimberly Campo provided support for calibration and maintenance of continuous water-quality monitoring in the field. Jason Sorenson helped install flow-gaging and other equipment at field locations. Kirk Smith developed the software programs that were used to control composite sample collection, data retrieval, data review, and data archiving and provided valuable insights into data interpretation. Laura Blake and Leslie DeSimone provided expertise in design of the water-quality sampling and processing protocols and data review and validation. Nick Stasulis, Greg Stewart, and Gardner Bent provided information on methods of discharge measurement. Leslie DeSimone, Jeffrey Kvech, and Gardner Bent provided helpful peer reviews. 



\section{Contents}

Acknowledgments ……...................................................................................................................

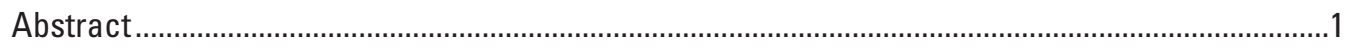

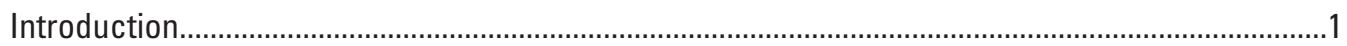

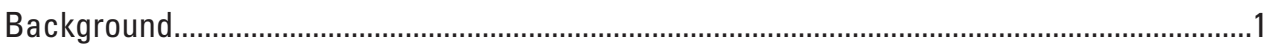

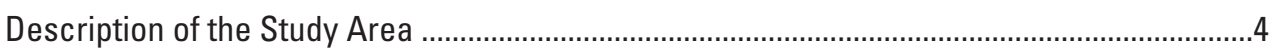

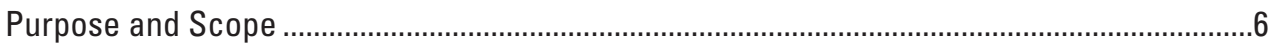

Methods of Measuring Discharge and Water Quality and Estimating Nutrient Fluxes....................6

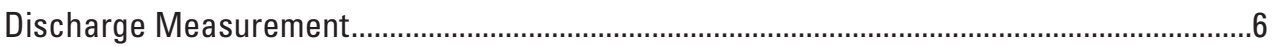

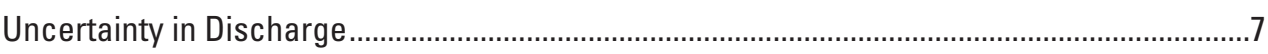

Continuous Water-Quality Measurements ........................................................................

Collection and Processing of Composite and Discrete Water-Quality Samples .......................8

Quality Assurance/Quality Control on Composite Sampling ....................................................13

Analytical Methods and Quality Assurance .............................................................................14

Modeling Nutrient Fluxes Across the Ocean-Estuary Boundary With LOADEST.....................15

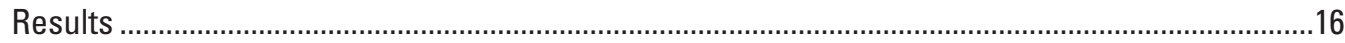

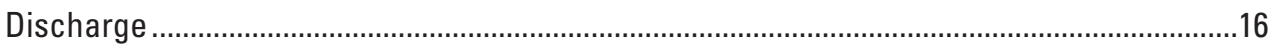

Air Temperature, Water Temperature, and Precipitation Measurements ..............................19

Continuous Water-Quality Measurements at Herring River at Chequessett Neck Road .......21

Variation in Nutrient Concentrations in the Herring River by Season, Antecedent

Precipitation, and Tide Direction ...........................................................................30

Nutrient Fluxes Across the Ocean-Estuary Boundary ...........................................................34

Continuous Water-Quality Measurements at Tributaries to the Herring River ........................42

Variation in Nutrient Concentrations in the Tributaries to the Herring River............................50

Summary and Conclusions.................................................................................................

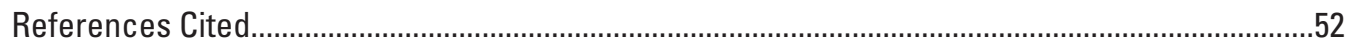

Appendix 1. LOADEST Models Selected and Bias Statistics for Estimating Nutrient Fluxes Across the Ocean-Estuary Boundary on the Herring River at Chequessett Neck Road, Wellfleet, Massachusetts

Appendix 2. LOADEST Regression Equations Used To Estimate Nutrient Loads Across the Ocean-Estuary Boundary on the Herring River at Chequessett Neck Road, Wellfleet, Massachusetts

\section{Figures}

1. Map showing the Herring River in Wellfleet, Massachusetts, on Cape Cod, the watershed basin boundary, monitoring stations, tributaries, and major soil series .........3

2. Plot showing measured radar unit sensor velocity in relation to measured acoustic Doppler current profiler cross-sectional velocity for the Herring River at the Chequessett Neck Road dike, Wellfleet, Massachusetts, from June 24, 2015, through September 30, 2017

3. Graphs showing discharge, measured nutrient concentrations for discrete samples, and calculated flow-weighted composite concentrations for the flood and ebb tides, Herring River at Chequessett Neck Road in Wellfleet, Massachusetts, 2016 
4. Graphs showing computed mean discharge rates for tidal days for the Herring River at Chequessett Neck Road in Wellfleet, Massachusetts, from November 2015 through September 2017.

5. Graph showing monthly precipitation in Truro, Massachusetts, and estimated daily mean ebb tide discharge for each month for the Herring River at Chequessett Neck Road in Wellfleet, Mass., from November 2015 through September 2017...

6. Time series showing water temperature in the Herring River on the salt marsh side of the dike at Chequessett Neck Road in Wellfleet, Massachusetts, and daily average air temperature and precipitation in Truro, Mass., from November 2015 through September 2017.

7. Time series showing monthly average precipitation in Truro, Massachusetts, for 2016, 2017, and the long-term average......

8. Time series showing concentrations of dissolved oxygen at the Herring River on the river side of the dike at Chequessett Neck Road in Wellfleet, Massachusetts, November 2015 through September 2017.

9. Time series showing dissolved oxygen, $\mathrm{pH}$, and gage height for the Herring River on the river side of the dike at Chequessett Neck Road in Wellfleet, Massachusetts, during mid-July 2017

10. Time series showing $\mathrm{pH}$ for the Herring River at the dike at Chequessett Neck Road on the river side of the dike in Wellfleet, Massachusetts, November 2015 through September 2017.

11. Time series showing specific conductance on the ebb tide and flood tide, the long-term trend in gage height on the ebb tide, and surface velocity on the ebb tide and flood tide for the Herring River at the dike at Chequessett Neck Road on the river side of the dike in Wellfleet, Massachusetts, November 2015 through September 2017.

12. Time series showing specific conductance and gage height for the Herring River on the river side of the dike at Chequessett Neck Road in Wellfleet, Massachusetts, for the period from June 16, 2017, to June 27, 2017

13. Time series showing temperature and gage height for the Herring River at the dike on the river side of Chequessett Neck Road in Wellfleet, Massachusetts.

14. Graph showing ammonium concentrations in the Herring River at Chequessett Neck Road in Wellfleet, Massachusetts, for flow-weighted composite samples from sequential flood and ebb tides, November 2015 through September 2017.

15. Graph showing nitrate concentrations in the Herring River at Chequessett Neck Road in Wellfleet, Massachusetts, for flow-weighted composite samples from sequential flood and ebb tides, November 2015 through September 2017.

16. Graph showing total nitrogen concentrations in the Herring River at Chequessett Neck Road in Wellfleet, Massachusetts, for flow-weighted composite samples from sequential flood and ebb tides, November 2015 through September 2017.

17. Graph showing orthophosphate concentrations in the Herring River at Chequessett Neck Road in Wellfleet, Massachusetts, for flow-weighted composite samples from sequential flood and ebb tides, November 2015 through September 2017.

18. Graph showing total dissolved phosphorus concentrations in the Herring River at Chequessett Neck Road in Wellfleet, Massachusetts, for flow-weighted composite samples from sequential flood and ebb tides, November 2015 through September 2017. 
19. Graph showing total phosphorus concentrations in the Herring River at Chequessett Neck Road in Wellfleet, Massachusetts, for flow-weighted composite samples from sequential flood and ebb tides, November 2015 through September 2017.

20. Graph showing silica concentrations in the Herring River at Chequessett Neck Road in Wellfleet, Massachusetts, for flow-weighted composite samples from sequential flood and ebb tides, November 2015 through September 2017.

21. Graph showing dissolved organic carbon concentrations in the Herring River at Chequessett Neck Road in Wellfleet, Massachusetts, for flow-weighted composite samples from sequential flood and ebb tides, November 2015 through September 2017.

22. Time series showing daily precipitation measured in Truro, Massachusetts, and dissolved oxygen in surface water at Pole Dike Creek and Bound Brook in Wellfleet, Mass., during May 2016 through June 2017.

23. Time series showing gage height at Pole Dike Creek and diurnal variation in dissolved oxygen in surface water at Pole Dike Creek and Bound Brook in Wellfleet, Massachusetts, during August 8 through August 21, 2016

24. Time series showing daily precipitation measured in Truro, Massachusetts, and $\mathrm{pH}$ in surface water at Pole Dike Creek and Bound Brook in Wellfleet, Mass., during May 2016 through June 2017

25. Time series showing daily precipitation in Truro, Massachusetts, and variation in $\mathrm{pH}$ in surface water at Pole Dike Creek and Bound Brook in Wellfleet, Mass., during March 12 through April 8, 2017.

26. Time series showing daily precipitation measured in Truro, Massachusetts, and specific conductance in surface water at Pole Dike Creek and Bound Brook in Wellfleet, Mass., during May 2016 through June 2017.

27. Time series showing gage height and diurnal variation in specific conductance in surface water at Pole Dike Creek in Wellfleet, Massachusetts, August 8 through August 21, 2016

28. Time series showing daily precipitation measured in Truro, Massachusetts, and surface-water temperature at Pole Dike Creek and Bound Brook in Wellfleet, Mass., during May 2016 through June 2017.

29. Graph showing total nitrogen concentrations in Pole Dike Creek in Wellfleet, Massachusetts, for flow-weighted composite samples from sequential flood and ebb tides over a 24-hour period, May 2016 to August 2017

30. Graph showing total phosphorus concentrations in Pole Dike Creek in Wellfleet, Massachusetts, for flow-weighted composite samples from sequential flood and ebb tides over a 24-hour period, May 2016 to August 2017

31. Graph showing total nitrogen and total phosphorus concentrations in Bound Brook in Wellfleet, Massachusetts, for flow-weighted composite samples over a 24-hour period, May 2016 to June 2017 


\section{Tables}

1. Location coordinates, station types, and periods of records for streamflowand water-quality-monitoring stations on the Herring River in Wellfleet, Massachusetts.

2. Summary of water-quality laboratory analytical methods, U.S. Geological Survey parameter codes, method references, and minimum detection limits for samples collected at water-quality-monitoring stations on the Herring River, Wellfleet, Massachusetts.

3. Watershed contributing areas, average discharge, and associated rate of streamflow of U.S. Geological Survey streamgages on or near Cape Cod, Massachusetts, from November 1, 2015, to September 30, 2017

4. Kendall rank correlations between nutrient concentrations and cumulative precipitation in the previous 7 days in the Herring River at Chequessett Neck Road, Wellfleet, Massachusetts.

5. Seasonal and annual nutrient loads computed in LOADEST for flood and ebb tides, and estimation of the fraction of the ebb tide that is derived from the Herring River in Wellfleet, Massachusetts, calculated as ebb minus flood.

\section{Conversion Factors}

U.S. customary units to International System of Units

\begin{tabular}{|c|c|c|}
\hline Multiply & By & To obtain \\
\hline \multicolumn{3}{|c|}{ Length } \\
\hline inch (in.) & 2.54 & centimeter $(\mathrm{cm})$ \\
\hline foot $(\mathrm{ft})$ & 0.3048 & $\operatorname{meter}(\mathrm{m})$ \\
\hline mile (mi) & 1.609 & kilometer $(\mathrm{km})$ \\
\hline mile, nautical (nmi) & 1.852 & kilometer $(\mathrm{km})$ \\
\hline \multicolumn{3}{|c|}{ Area } \\
\hline square mile $\left(\mathrm{mi}^{2}\right)$ & 259.0 & hectare (ha) \\
\hline square mile $\left(\mathrm{mi}^{2}\right)$ & 2.590 & square kilometer $\left(\mathrm{km}^{2}\right)$ \\
\hline \multicolumn{3}{|c|}{ Volume } \\
\hline ounce, fluid (fl. oz) & 29.57 & milliliter (mL) \\
\hline gallon (gal) & 3.785 & liter $(\mathrm{L})$ \\
\hline cubic foot $\left(\mathrm{ft}^{3}\right)$ & 0.02832 & cubic meter $\left(\mathrm{m}^{3}\right)$ \\
\hline \multicolumn{3}{|c|}{ Flow rate } \\
\hline foot per second $(\mathrm{ft} / \mathrm{s})$ & 0.3048 & meter per second $(\mathrm{m} / \mathrm{s})$ \\
\hline cubic foot per second $\left(\mathrm{ft}^{3} / \mathrm{s}\right)$ & 0.02832 & cubic meter per second $\left(\mathrm{m}^{3 /} \mathrm{s}\right)$ \\
\hline $\begin{array}{l}\text { cubic foot per second per square mile } \\
\qquad\left(\left[\mathrm{ft}^{3} / \mathrm{s}\right] / \mathrm{mi}^{2}\right)\end{array}$ & 0.01093 & $\begin{array}{l}\text { cubic meter per second per square kilome- } \\
\operatorname{ter}\left(\left[\mathrm{m}^{3} / \mathrm{s}\right] / \mathrm{km}^{2}\right)\end{array}$ \\
\hline \multicolumn{3}{|c|}{ Precipitation } \\
\hline inches per year (in/yr) & 2.54 & centimeters per year $(\mathrm{cm} / \mathrm{yr})$ \\
\hline \multicolumn{3}{|c|}{ Mass } \\
\hline pound, avoirdupois (lb) & 0.4536 & kilogram (kg) \\
\hline pound, avoirdupois, per day (lb/d) & 0.4536 & kilogram per day $(\mathrm{kg} / \mathrm{d})$ \\
\hline
\end{tabular}

Temperature in degrees Celsius $\left({ }^{\circ} \mathrm{C}\right)$ may be converted to degrees Fahrenheit $\left({ }^{\circ} \mathrm{F}\right)$ as ${ }^{\circ} \mathrm{F}=\left(1.8 \times{ }^{\circ} \mathrm{C}\right)+32$. 


\section{Datum}

Vertical coordinate information is referenced to the North American Vertical Datum of 1988 (NAVD 88).

Horizontal coordinate information is referenced to the North American Datum of 1983 (NAD 83).

Elevation, as used in this report, refers to the distance above the vertical datum.

\section{Supplemental Information}

Specific conductance is given in microsiemens per centimeter at 25 degrees Celsius $(\mu \mathrm{S} / \mathrm{cm}$ at $\left.25^{\circ} \mathrm{C}\right)$.

Concentrations of chemical constituents in water are given in milligrams per liter (mg/L). 


\section{Abbreviations}

\begin{tabular}{|c|c|}
\hline AMLE & adjusted maximum likelihood estimate \\
\hline$B_{p}$ & load bias \\
\hline CACO & Cape Cod National Seashore \\
\hline DD & diked and drained \\
\hline DF & diked and seasonally flooded \\
\hline DO & dissolved oxygen \\
\hline DOC & dissolved organic carbon \\
\hline DQ0 & data quality objective \\
\hline$E$ & Nash-Sutcliffe efficiency index \\
\hline ENV & environmental [samples] \\
\hline EWI & equal width increment \\
\hline HRW & Herring River watershed \\
\hline N & nitrogen \\
\hline $\mathrm{NH}_{4}$ & ammonium \\
\hline $\mathrm{NO}_{2}$ & nitrite \\
\hline $\mathrm{NO}_{3}$ & nitrate \\
\hline NPS & National Park Service \\
\hline NWIS & National Water-Information System \\
\hline$P$ & phosphorus \\
\hline PCR & partial concentration ratio \\
\hline PLR & partial load ratio \\
\hline $\mathrm{PO}_{4}$ & phosphate \\
\hline QA & quality assurance \\
\hline RPD & relative percent difference \\
\hline $\mathrm{SiO}_{2}$ & silica \\
\hline $\mathrm{SpC}$ & specific conductance \\
\hline TDN & total dissolved nitrogen \\
\hline TDP & total dissolved phosphorus \\
\hline TN & total nitrogen \\
\hline TP & total phosphorus \\
\hline USGS & U.S. Geological Survey \\
\hline
\end{tabular}




\title{
Assessment of Water Quality and Discharge in the Herring River, Wellfleet, Massachusetts, November 2015 to September 2017
}

\author{
By Thomas G. Huntington, Alana B. Spaetzel, John A. Colman, Kevin D. Kroeger, and Robert T. Bradley
}

\section{Abstract}

The U.S. Geological Survey, Cape Cod National Seashore of the National Park Service, and Friends of Herring River cooperated from 2015 to 2017 to assess nutrient concentrations and fluxes across the ocean-estuary boundary at a dike on the Herring River in Wellfleet, Massachusetts. The purpose of this assessment was to characterize environmental conditions prior to a future removal of the dike, which has restricted saltwater inputs into the Herring River watershed for more than 100 years. Water temperature, dissolved oxygen, $\mathrm{pH}$, and specific conductance were monitored continuously, and flow-weighted composite samples were collected approximately twice per month at the ocean-estuary boundary. Bidirectional discharge was computed for the U.S. Geological Survey Herring River at Chequessett Neck Road at Wellfleet, Massachusetts, streamgage (011058798) by using a stage-area rating and index-velocity ratings developed with acoustic Doppler current profile measurements made upstream and downstream from the dike. LOADEST regression modeling software was used to estimate nutrient fluxes (loads) from composite, paired nutrient concentration and discharge data in conjunction with continuous discharge data. Temperature, dissolved oxygen, $\mathrm{pH}$, and specific conductance were also monitored continuously on two tributaries to the Herring River, Pole Dike Creek and Bound Brook, from late-May 2016 to mid-June 2017. Composite or discrete water samples were collected from the tributaries approximately twice per month in most months from late-May 2016 to mid-June 2017 and analyzed for total nitrogen, total phosphorus, and dissolved organic carbon.

Flow-weighted concentrations of ammonium, nitrate, and total nitrogen on the Herring River at the dike on the ebb tide generally varied between 0.01 and $0.1,0.003$ and 0.03 , and 0.3 and 0.7 milligram per liter as nitrogen, respectively. Flowweighted concentrations of orthophosphate, total dissolved phosphorus, and total phosphorus generally varied between 0.002 and $0.02,0.003$ and 0.06 , and 0.03 and 0.1 milligram per liter as phosphorus, respectively, on the ebb tide. Flowweighted concentrations of silicate and dissolved organic carbon on the ebb tide generally varied between 0.08 and
3.0 milligrams per liter of silica (silicon dioxide), and 1.7 and 5.6 milligrams per liter of carbon, respectively. Ebb tide concentrations of nitrate were highest in winter and lowest in summer. By contrast, ebb tide concentrations of phosphorus species were highest in late summer and early fall and lowest in winter. Silica and dissolved organic carbon did not exhibit systematic variation in seasonal concentrations. There was uncertainty in estimates of nutrient fluxes, but the LOADESTestimated fluxes indicated that annual (and in almost all cases seasonal) exports (ebb tides) exceeded inputs (flood tides). Ebb tide concentrations of ammonium, nitrate, total nitrogen, and silica were positively correlated with antecedent cumulative 7-day precipitation.

\section{Introduction}

To characterize environmental conditions in advance of the removal of a dike at the Herring River in Wellfleet, Massachusetts, the U.S. Geological Survey (USGS), in cooperation with the National Park Service, Cape Cod National Seashore, and Friends of Herring River assessed nutrient concentrations and fluxes across the ocean-estuary boundary from 2015 to 2017.

\section{Background}

The Cape Cod National Seashore (CACO) of the National Park Service (NPS) is preparing to restore the Herring River salt marsh that has been diked off from the ocean for more than 100 years. Restoration will consist of restoring tidal flushing to large parts of the former salt marsh. Restoration of the marsh is expected to result in improvements in coastal habitat, ecosystem services, and water quality from increased tidal exchange (Portnoy, 1999; Portnoy and Allen, 2006). Restoration will potentially improve water and soil quality, increase river herring and shellfish habitat, minimize the spread of invasive plant species, and provide improved recreational opportunities, among other benefits (Tim Smith, NPS, written commun., 2016). Salt marsh restoration 
(movement towards targets in vegetation, fish, and bird assemblages) by restoring previously restricted tidal inputs has been documented in New England (Warren and others, 2002; Roman and Burdick, 2012; Chaffee and others, 2012). To monitor biogeochemical and hydrologic changes that may occur in response to increased tidal exchange, restoration will proceed incrementally during an adaptive management phase by use of adjustable gates at Chequessett Neck Road. The restoration planning process is being overseen by the CACO NPS, the Herring River Restoration Committee, and Friends of Herring River.

Diking of substantial areas of subtidal zone, salt marsh, brackish wetlands, freshwater wetlands, and woodlands in the Herring River watershed have degraded habitats with severe ecological consequences (Soukup and Portnoy, 1986). Diking and ditching, primarily for mosquito control, have resulted in the oxidation of pyrites, causing acidified leachates to lower $\mathrm{pH}$ and mobilize aluminum. Habitat degradation in surface waters has included depletion of dissolved oxygen (DO) (Portnoy, 1991), increases in acidity and aluminum (which is toxic to sensitive aquatic biota) (Soukup and Portnoy, 1986), and increases in fecal coliform concentrations (Portnoy and Allen, 2006). Habitat degradation in wetlands has also included loss of salt marsh species, including salt meadow grass (Spartina patens), smooth cordgrass (Spartina alterniflora), black grass (Juncus gerardii), and spike grass (Distichlis spicata) (Roman, 1987).

The acidification of surface waters following diking and drainage can also result in losses of fish and other organisms. For example, in 1980, mosquito-control ditching and accompanying sediment disturbance and aeration following heavy rainfall resulted in a die-off of thousands of American eels (Anguilla rostrata) and other fish species (Soukup and Portnoy, 1986). The Massachusetts Division of Marine Fisheries and the NPS determined that the cause of the fish kill was highly acidic water ( $\mathrm{pH}$ less than $[<] 4.0)$ and toxic aluminum released into the main channel of Herring River (Soukup and Portnoy, 1986). In 2003, water-quality problems caused the Massachusetts Department of Environmental Protection to list the Herring River as "impaired" under section 303(d) of the Clean Water Act (USC $\$ 1251$ et seq.) for low pH and high metal concentrations. In 1983, summertime DO depletion was recorded in the Herring River estuary and river herring (Alosa spp.) kills were documented for the first time (Portnoy, 1991). The NPS then took steps to protect river herring by blocking their emigration from upstream ponds to prevent the fish from entering low-oxygen waters (Herring River Technical Committee, 2007).

Fecal coliform contamination in extensive beds of eastern oysters (Crassostrea virginica) and cultured hard clams (Mercenaria mercenaria) up to 2 kilometers $(\mathrm{km})$ seaward of the diked Herring River estuary has resulted in shellfish bed closures, at least seasonally, since statewide surveillance increased in 1983 (Portnoy and Allen, 2006). Portnoy and Allen (2006) identified conditions in the benthic environment above the dike as conducive to the persistence and mobilization of fecal coliform bacteria following large rainfall events. They reported that restored tidal flow would reduce coliform survival time by increasing salinity, $\mathrm{DO}$, and $\mathrm{pH}$, all presently depressed throughout the system because of the biogeochemical disturbance that results from diking and drainage.

Diking of the marsh ecosystem profoundly altered the hydrology and chemistry of the marsh upstream from the dike. Portnoy and Giblin (1997a, b) described two distinctly different altered marsh environments postdiking. They described one system as diked and drained (DD) and a second system as diked and seasonally flooded (DF). The DD environments are restricted to the middle Herring River, lower Pole Dike Creek, and lower Duck Harbor sector flood plain (fig. 1) and roughly correspond to the areas mapped as Maybid soil series.

In the DD systems, dewatering resulted in air penetration into previously anoxic sediments, which led to oxidation of pyrite, generation of acidity, and release of toxic aluminum (Portnoy and Giblin, 1997b). Aerobic conditions in the organic sediments resulted in rapid decomposition compared with the prediked condition. Rapid decomposition resulted in substantial subsidence ( 1 meter [m] or more) of the marsh surface. In the face of ongoing sea-level rise, coastal marshes must increase in elevation at rates greater than or equal to the rate of sea-level rise. The dynamics of marsh elevation change depend on various processes, including sediment transport and deposition on marsh surfaces and the growth of salt marsh vegetation. Diking and drainage has effectively prevented sediment from reaching many areas of the Herring River flood plain (National Park Service and others, 2016).

In the DD sediments, ammonium $\left(\mathrm{NH}_{4}\right)$ has accumulated through ion exchange on surfaces, and phosphate $\left(\mathrm{PO}_{4}\right)$ has accumulated on iron oxides. Column experiments indicated that restoration of saltwater tidal flushing in these sediments will likely result in mobilization and release of $\mathrm{NH}_{4}$ and $\mathrm{PO}_{4}$, as well as iron (II) (Portnoy and Giblin, 1997b). A major nutrient release, even if short lived, could adversely affect aquaculture in Wellfleet Harbor through eutrophication, leading to hypoxia. This specific concern is one of the major reasons that the restoration planning process includes a phased or incremental reintroduction of saltwater to allow for adaptive management.

The accumulation of nitrogen and phosphorus in the sediments of Herring River that occurred postdiking, as indicated by Portnoy and Giblin (1997b), are thought to have remained high (National Park Service and others, 2016). Potential sources of nutrient inputs to the watershed include agriculture, fertilized lawns, a golf course, a landfill, leaking septic systems, animal waste, and atmospheric deposition. The inputs have not been quantified. The lack of tidal flushing has allowed nutrients to accumulate in the Herring River watershed (Portnoy and Giblin, 1997b; National Park Service and others, 2016).

The fringing marshes associated with the lower parts of Bound Brook (fig. 1) are assumed to be analogs for the DF systems that were described by (Portnoy and Giblin, 1997a). Prior to diking, DF systems were brackish marshes that were 


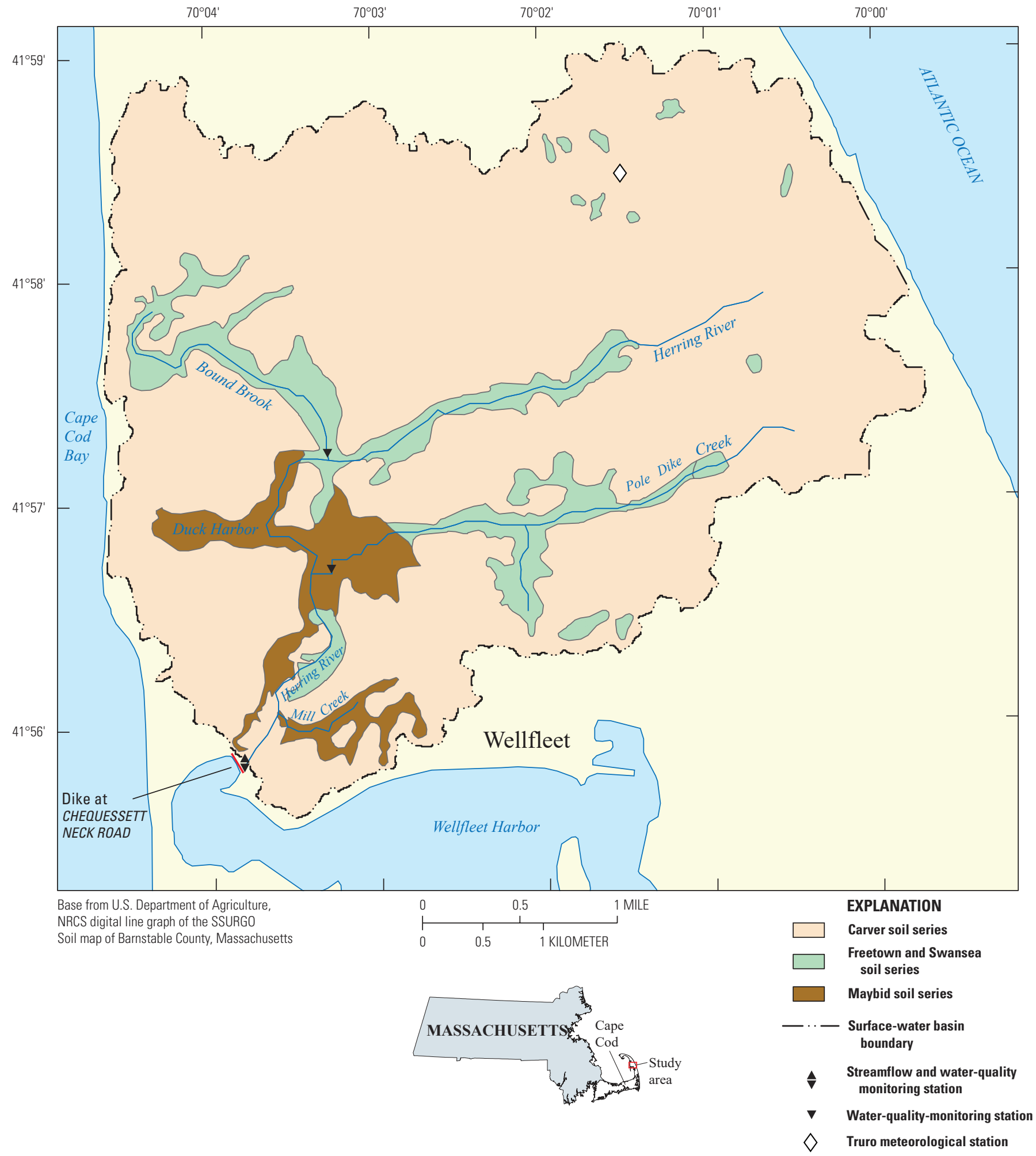

Figure 1. The Herring River in Wellfleet, Massachusetts, on Cape Cod, the watershed basin boundary, monitoring stations, tributaries, and major soil series. 
subject to tidal flooding and draining, but after diking, these marshes were no longer affected by tidal flooding. In their current (prerestoration) condition, they are not subjected to saltwater because tidal inputs are restricted to about $1,000 \mathrm{~m}$ upstream from the dike (Portnoy and Allen, 2006). These fringing marshes are now seasonally flooded with freshwater. These seasonally flooded freshwater marshes that have not had tidal saltwater or substantial mineral sediment inputs for 100 years have experienced slow rates of decomposition under methanogenesis, allowing a buildup of peat material that is low in mineral content. Restoration of tidal inputs will likely result in a shift from slower methanogenesis to faster sulfate reduction, which could lead to increased nutrient release, and in accumulation of sulfide, which could inhibit establishment of vegetation as non-salt-tolerant species die out (Portnoy and Giblin, 1997a).

Concerns have also been expressed that restoration of tidal exchange could result in a short-term mobilization and transport of fine-grained sediments that have accumulated upstream from the dike. If a large amount of fine-grained sediments was transported out of the Herring River, it has been suggested that this sediment could smother or otherwise adversely affect the shellfish aquaculture in Wellfleet Harbor. This potential net export of sediment would likely be short lived. Over the longer term, net sediment transport is expected to be upstream into the Herring River with resulting deposition on flood plains (Woods Hole Group, 2012).

Silica is an important nutrient for the growth of phytoplankton (for example, diatoms) (Cornelis and others, 2011), and its biogeochemistry could be affected by the restoration. Silica retention and release may be influenced by hydrology (for example, tidal flushing and major runoff events), changes in vegetation, and mobilization of sediments (Cornelis and others, 2010; Struyf and Conley, 2012). The integrated response (retention or release) is difficult to predict because of the multiple factors that can influence the processes involved (Struyf and Conley, 2012).

The primary objective of this study was to develop a prerestoration baseline database with 2 years of data for the Herring River at Chequessett Neck Road on discharge, nutrient and dissolved organic carbon fluxes, and continuous water-quality parameters (salinity, $\mathrm{pH}$, temperature, and DO) for tidal inflows (flood tides) and outflows (ebb tides). This prerestoration baseline is intended for reference during phased tidal restoration to inform adaptive management in response to the effects of restoration on water quality. The data can be used to help measure progress toward restoration objectives for the Herring River salt marsh. Data collection was intended to encompass a wide range of natural variation based on seasonal changes and responses to variation in climatic and hydrologic conditions. The data in this report can be supplemented with additional data collected in a followup study that reported nutrient concentrations at this site for the period from October 1, 2017, to September 30, 2018, and those data are archived in the USGS National Water Information System (NWIS) database (U.S. Geological Survey, 2019). Another
USGS study began measuring nutrient concentrations at this site in June of 2020. The additional nutrient concentration data from these followup studies will provide a more comprehensive understanding of natural variability under a broader range of hydrologic conditions. A secondary objective was to develop a prerestoration baseline database on total dissolved nitrogen (TDN), total dissolved phosphorus (TDP), and dissolved organic carbon (DOC) concentrations and continuous water-quality parameters (salinity, $\mathrm{pH}$, temperature, and $\mathrm{DO}$ ) for two tributaries to the Herring River.

\section{Description of the Study Area}

The drainage area of the Herring River watershed (HRW), in Wellfleet, Mass., at the dike on Chequessett Neck Road (USGS station 011058798) on Cape Cod, is not precisely defined because the contributing groundwater drainage area is not coincident with the surface-water drainage area (Masterson, 2004) and this basin is groundwater dominated (LeBlanc and others, 1986). The surface-water drainage area is approximately 28.5 square kilometers $\left(\mathrm{km}^{2}\right)$ based on the USGS StreamStats application (https://water.usgs.gov/osw/ streamstats/; U.S. Geological Survey, 2015) for Massachusetts. The groundwater-contributing area for the Herring River has been simulated by use of a three-dimensional numerical model (MODFLOW) to be approximately $19.1 \mathrm{~km}^{2}$ (Carlson and others, $2017 \mathrm{a}, \mathrm{b}$ ). In the interpretation of this simulation, the kettle ponds in the northwestern portion of the surface-water drainage area (not shown in fig. 1) are not included in the groundwater-contributing area.

The HRW contains a 600-hectare estuarine marsh complex that is the largest diked wetland system on Cape Cod. The HRW was diked off from the ocean in 1909, resulting in greatly restricted tidal flushing (Portnoy and Allen, 2006). There are four subbasins in the Herring River (Duck Harbor, Mill Creek, Pole Dike Creek, and Bound Brook; fig. 1). In this study, water-quality data were obtained from two of these drainages (Pole Dike Creek and Bound Brook; table 1). The four subbasins are briefly described in the Herring River final environmental impact statement/environmental impact report (National Park Service and others, 2016). The dike restricts tidal amplitude from about $2.1 \mathrm{~m}$ seaward to $0.5 \mathrm{~m}$ landward of the structure (Portnoy and Allen, 2006). The dike was intended to control mosquitoes, create additional developable land, and provide for road construction. After the original dike construction, widespread ditching, straightening, and channelizing of the meandering creeks effectively drained most of the remaining salt marshes (National Park Service and others, 2016). Between 1929 and 1933, a golf course was constructed, partly on what had previously been part of the Mill Creek (tributary to the Herring River) flood plain. Additionally, several homes have been constructed in the former flood plain.

The dike structure is an earthen dam about $0.15 \mathrm{~km}$ in length that contains a culvert with three approximately 4-square-meter rectangular sluiceways in the center of the 
Table 1. Location coordinates, station types, and periods of records for streamflow- and water-quality-monitoring stations on the Herring River in Wellfleet, Massachusetts.

[Locations of monitoring stations are shown in figure 1. Latitude and longitude are given relative to the North American Datum of 1983 (NAD 83 ). USGS, U.S. Geological Survey; MA, Massachusetts; QW, water quality; _, no data]

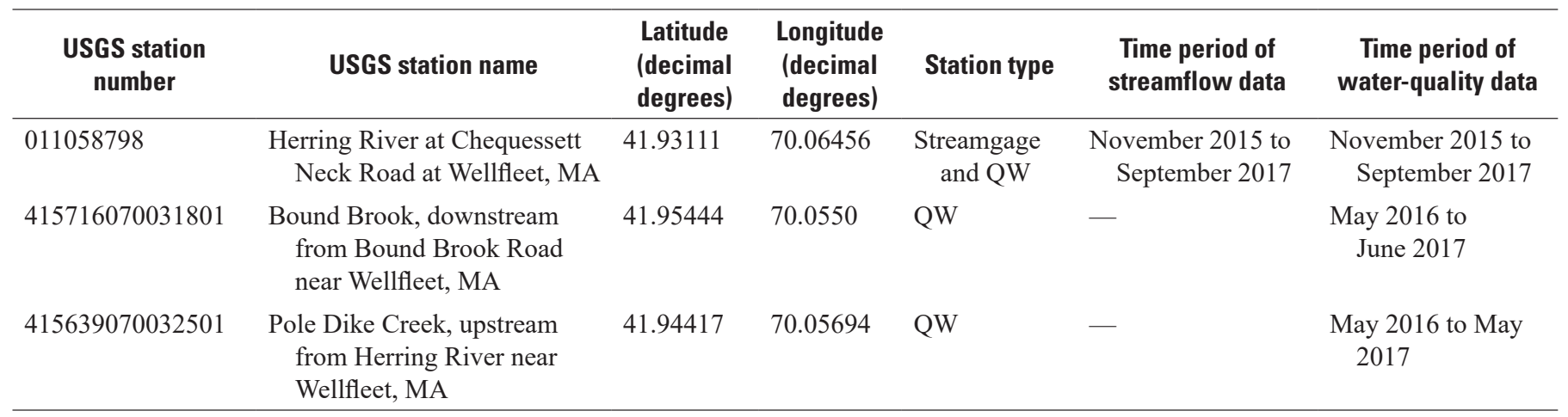

dike. Within two of the three sluiceways (center and northwest sluiceways), hydraulic pressure-controlled flapper gates permit ebb discharge and close following an ebb tide, thereby restricting seawater flow upstream during flood tides (Portnoy and Allen, 2006). The third sluiceway (southeast sluiceway) is a fixed gate that is partially open. This sluiceway allows ebb discharge and is the only sluiceway that allows seawater to flow upstream during flood tides. With the present dike configuration, seawater travels upstream about 1,000 $\mathrm{m}$ into the estuary and marsh complex (Portnoy and Allen, 2006). The dike structure results in tidal asymmetry such that flood tides average 7.2 hours and ebb tides average 5.2 hours during each complete cycle. The tidal cycle in the ocean is consistent with semidiurnal tides (average periodicity of 12.4 hours) for the Gulf of Maine (Garrett, 1972).

Prior to diking, the tidal flats and low marsh areas were dominated by Spartina alterniflora and the high marsh area was dominated by Spartina patens. Following diking, that vegetation was replaced by brackish and freshwater species: sedges (Scirpus spp.), Typha spp., forbs, shrubs, and grasses (Roman, 1987). Diking also affected the populations of many fish, shellfish and other invertebrates, birds, mammals, reptiles, and amphibians (National Park Service and others, 2016).

The mean annual temperature at nearby Truro, Mass., was 12.3 degrees Celsius $\left({ }^{\circ} \mathrm{C}\right)$ from October 2004 through September 2017 (Western Regional Climate Center, 2018). The Truro meteorological station is located $5.85 \mathrm{~km}$ northeast from the Herring River monitoring station. Mean monthly air temperature is usually between 1 and $4{ }^{\circ} \mathrm{C}$ from December through February and between $21^{\circ} \mathrm{C}$ and $24^{\circ} \mathrm{C}$ from June through August. The mean annual precipitation near Truro was 121 centimeters $(\mathrm{cm})$ for the period January 1983 to December 2017 (National Atmospheric Deposition Program, 2018). Precipitation is fairly evenly distributed among months and generally averages between 8 and $12 \mathrm{~cm}$ per month but can be highly variable in any given month (from $<1$ to greater than $[>] 13 \mathrm{~cm}$ ). Groundwater recharge on Cape Cod is about 45 percent of total annual precipitation (LeBlanc and others, 1986).

Various characteristics of the basin, as defined by the surface-water drainage area, are described in the USGS StreamStats application (https://water.usgs.gov/osw/ streamstats/; U.S. Geological Survey, 2015). The watershed is entirely underlain by glacially derived coarse-grained stratified drift. Forests cover 71 percent of the watershed surface area, wetlands cover 15 percent, ponds cover 4.6 percent, and developed land (largely the suburban town of Wellfleet, Mass.) occupies about 13.2 percent. Percentages sum to $>100$ percent because some of the forested land is also classified as wetlands. About 3 percent of the developed land is classified as impervious surface. The mean watershed elevation is $14.4 \mathrm{~m}$, and the total length of all mapped streams (1:24,000-scale) in the watershed is $31.2 \mathrm{~km}$.

The soils in the HRW are about 80 percent Carver coarse sands in upland areas on slopes ranging from 0 to 3 percent to 15 to 35 percent, with roughly half in the steeper category (fig. 1; Natural Resources Conservation Service, 2018). The wetland marsh complex, covering about 10 percent of the HRW, is predominantly Freetown and Swansea mucks located in marshes fringing upper Pole Dike Creek, upper Herring River, and Bound Brook. The only other substantial soil coverage is the Maybid variant silty clay loam in the middle Herring River, lower Pole Dike, lower Duck Harbor, and Mill Creek areas. The Carver soil series consists of deep, excessively drained soils on outwash plains and typically supports forest vegetation (Fletcher, 1993). The Freetown and Swansea series consist of very deep and very poorly drained mucky peat soils on outwash plains or moraines that formed in decomposed organic material in freshwater environments. The Maybid variant soil series consists of very deep and poorly drained soils in tidal marshes that are no longer subject to tidal flooding. Maybid soils formed in loamy marine sediments drained of saltwater and are acidic. 
The water-sampling site (water-quality-monitoring station) at Pole Dike Creek is near the confluence of Pole Dike Creek and the Herring River (fig. 1). At this site, Pole Dike Creek drains a substantial area of the Maybid variant soil series that is described by Portnoy and Giblin (1997a) as DD acid sulfate soils. Streamflow reverses with the tides at this location, and the water is brackish, frequently exceeding 1,000 microsiemens per centimeter $(\mu \mathrm{S} / \mathrm{cm})$ at $25^{\circ} \mathrm{C}$ in the summer and fall. The water-quality-monitoring station at Bound Brook is near the confluence of Bound Brook and the Herring River. At this site, Bound Brook drains a substantial area of Freetown and Swansea mucky peat soils. Some of these fringing marsh soils in the lower parts of the Bound Brook drainage are similar to the DF systems described by Portnoy and Giblin (1997b).

\section{Purpose and Scope}

This report assesses water quality and discharge at the Herring River at Chequessett Neck Road, as well as water quality at the tributaries, Bound Brook and Pole Dike Creek, for a 2-year period prior to the planned restoration of the Herring River salt marsh. The report describes methods of continuous data collection, discrete and composite sampling, quality assurance, and modeling of nutrient fluxes. Waterquality results are presented in terms of ebb and flood tide and season. The complete datasets are available in the associated data release (Huntington and Spaetzel, 2020). These datasets provide a prerestoration baseline intended to inform adaptive management during the process of salt marsh restoration.

\section{Methods of Measuring Discharge and Water Quality and Estimating Nutrient Fluxes}

\section{Discharge Measurement}

A data collection platform at the dike on Chequessett Neck Road was maintained from June 23, 2015, through September 30, 2017. Separate sensors at the platform were used to collect surface-water velocity and stage data to facilitate the calculation of continuous flow in the Herring River estuary. Data were collected at 5-minute intervals except during actual periodic discharge measurements, when the data collection interval was changed to 1 minute to aid in rating development. Surface-water velocity was measured by using the contact-free Sommer Messtechnik GmbH RG-30 radar sensor (Sommer GmbH, 2014) on the upstream side (marsh side) of the dike. The radar sensor transmits a signal with a constant frequency at a specific angle to the water surface. There the signal is reflected by ripples or waves on the water surface and shifted in frequency (because of the Doppler effect) by an amount that is proportional to the water velocity. The reflected signal is received by the antenna of the radar sensor. By comparing the transmitted frequency to the frequency of the reflected signal from the water surface, the velocity can be determined.

The radar unit requires that the water be moving and have a minimum ripple height of about $3 \mathrm{~mm}$ (Sommer $\mathrm{GmbH}$, 2014). Testing at the U.S. Geological Survey Hydrologic Instrumentation Facility showed that the unit worked according to the manufacturer's specifications where the velocity was $>0.5$ foot per second ( $\mathrm{ft} / \mathrm{s}$ ) (Janice Fulford, U.S. Geological Survey, WMA Instrument News, volume 2016, issue 149, Surface Velocity Radar: HIF testing of the Sommer RG-30, 2016). At velocities $<0.5 \mathrm{ft} / \mathrm{s}$, the radar unit does not provide reliable information. Under turbulent conditions, waves can result that do not represent the movement of the water surface (for example, stationary waves), resulting in errors in the angle of the reflected signal and hence in the velocity measurement. The radar unit was calibrated and installed by the manufacturer's technical representative but not validated during the study period by comparing it with independent measurements of the surface velocity at the sensor location.

To translate the surface-water velocity at the point measured by the radar to a cross-sectional velocity of the river, a velocity-velocity relation was established with the velocity of discharge measurements made on a seasonal basis and during outgoing and incoming tides. The discharge measurements were made by using an acoustic Doppler current profiler and following the USGS techniques and methods described by Ruhl and Simpson (2005), Mueller and others (2013), and Levesque and Oberg (2012) across the channel, upstream or downstream from the dike depending on whether the tides were outgoing or incoming. Discharge measurements used in the index-velocity rating were made over about a 3-foot (ft) range in stage, from -2.31 to $0.26 \mathrm{ft}$ above the North American Vertical Datum of 1988, recorded on the marsh side of the dike. Discharge measurements were made on the upstream and downstream sides of the dike where the flow was smooth and measurable. Discharge measurements were made over the period of discharge record from June 24, 2015, through September 30, 2017. During this period, a total of 268 individual discharge measurements were made on 16 days. Of these, 13 discharge measurements were not used in the analyses of discharge because of instrument issues, such as bad stage record. Of the remaining 255 measurements, 83 were made during 8 outgoing tide cycles, generally on the upstream side (marsh side) of the dike. There were 172 discharge measurements made during 12 incoming tide cycles on the downstream side (ocean side) of the dike.

A stage-area rating (Levesque and Oberg, 2012) was developed for the upstream side of the dike where the stage sensor was located by using one of the individual discharge measurements made during the outgoing tide cycle on October 26, 2016. The stage-area rating was developed using the USGS AreaComp software. An index-velocity rating (Levesque and Oberg, 2012), in the form of a regression equation, was developed based on the relation of concurrent 
radar measurements of the surface velocity at the sensor location (index velocity) and the measured mean velocity of the river from discharge measurements. Because of the rapidly changing discharge at this tidal site, the index-velocity rating was developed by using individual discharge-measurement transects. A polynomial regression equation was determined to best describe the index-velocity rating for both the outgoing and incoming tidal flows (fig. 2). The polynomial regression equation was defined as

$$
y=0.0052 x^{2}+0.1794 x+0.1102
$$

where

$y \quad$ is the computed mean channel velocity and $x \quad$ is the index velocity measured by the radar surface-water velocity meter.

The outputs from each of these ratings, mean channel velocity from the index-velocity rating, and cross-sectional area from the stage-area rating were then multiplied together for each of the 5-minute values to compute instantaneous discharge.

\section{Uncertainty in Discharge}

The discharge record for the Herring River likely has more uncertainty than for typical streamgages because of challenging conditions at this site that could affect the velocity, stage, and cross-sectional area of the river. The following are some of the challenging conditions:

1. The incoming flow goes through only one of the three sluiceways, which is only open about $1 \mathrm{ft}$ at the bottom of the sluiceway. This results in a period of unsteady flow where surface velocities can exceed $15 \mathrm{ft} / \mathrm{s}$ and likely includes vertical as well as horizontal velocities. This period of extreme surface velocities can cause turbulence and a water surface with waves of complex and variable angles and foaming. These conditions are problematic for the radar sensor because it can cause errors in the angle as the radar impulse is reflected from the water surface (Sommer GmbH, 2014).

2. Rapid changes in the velocity and stage of the river were observed during some single-transect discharge measurements, which resulted in measurements of fair quality rating (within 8 percent of the true value) based on USGS standards.

3. The locations where discharge measurements could be made were limited to within several feet of the upstream and downstream sides of the dike. The funneling of the flow through the gates in the dike likely resulted in a variable cross-sectional velocity profile and possibly more uncertainty in the discharge measurement.
4. Shifting of channel bottoms (scour and fill) on both sides of the dike could have occurred, which could result in channel cross-sectional differences in the stagearea rating.

5. Debris catching in the gates in the sluiceways under the dike (and not visible) could affect how much the flapper gates open or close and could affect measured velocity and stage values.

6. Possible climatic effects, such as wind speed and direction on the ocean side of the dike or ice during the winter, could affect measured velocity and stage values.

These challenging conditions can be seen in the indexvelocity rating for the site, which show that the data points of concurrent surface-water velocity from the radar unit (index velocity) and the mean channel velocity of the individual transect discharge measurement (computed by dividing the discharge by the cross-sectional area of the measurement) were up to \pm 100 percent on both sides of the best-fit polynomial regression line (rating curve; fig. 2).

During brief periods, generally during the incoming flow (flood flow) when the surface-water velocity radar could not read the velocity because of turbulence, a velocity of $0.00 \mathrm{ft} / \mathrm{s}$ was recorded. Similarly, during variable-length periods (typically between 15 and 60 minutes) at slack tide, when the velocity was less than the minimum required or the ripple height was less than the minimum required for velocity detection by the radar unit, it frequently recorded $0.00 \mathrm{ft} / \mathrm{s}$. These recorded $0.00 \mathrm{ft} / \mathrm{s}$ velocities were deleted from the record because the velocities were not $0.00 \mathrm{ft} / \mathrm{s}$. For periods of missing or deleted velocity or stage data less than or equal to 120 minutes, the USGS water data management software AQUARIUS (Aquatic Informatics, Inc., 2019) was set to estimate the velocity, stage, and discharge values by interpolating between the last data value and the next data value. For data gaps greater than 120 minutes, no data were estimated.

The possible uncertainties associated with flood and ebb flows computed could be larger than the difference between these two flows that were estimated as the freshwater contribution of the Herring River to the ebb flow. Because of the possible uncertainties under these challenging conditions, the discharges computed should be considered poor (greater than 8 percent of the true value).

\section{Continuous Water-Quality Measurements}

At the Chequessett Neck Road monitoring station, continuously recording water-quality monitors were deployed at the upstream and downstream ends of the box culvert from November 2015 to September 2017. These two upstream monitors measured water temperature, $\mathrm{pH}$, specific conductance ( $\mathrm{SpC}$ ) (adjusted to $25^{\circ} \mathrm{C}$ ), and DO; the downstream monitor measured water temperature and $\mathrm{SpC}$ (Wagner and others, 2006). The Chequessett Neck Road monitoring station contained structures on both sides of the dike that recorded 


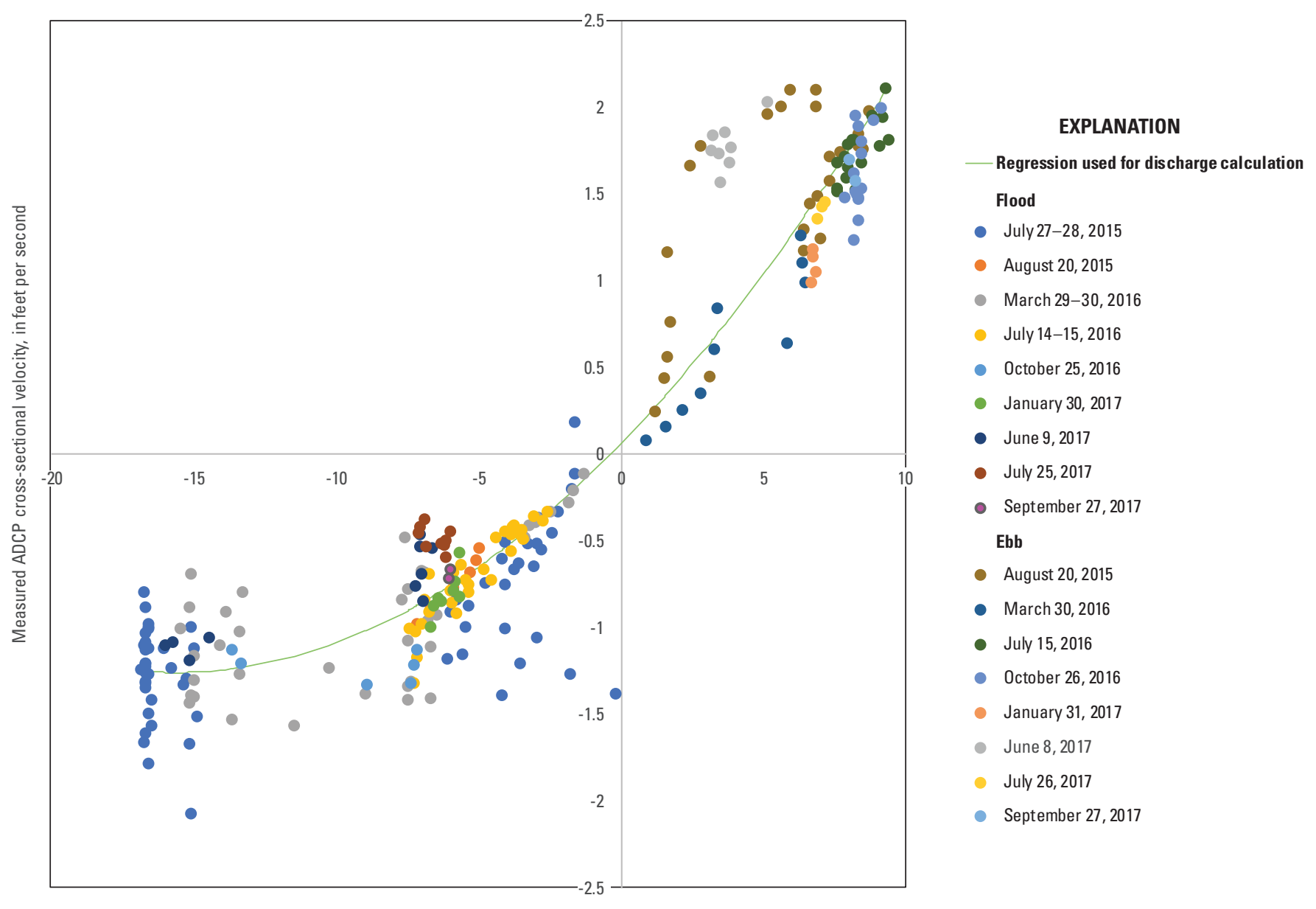

Measured radar unit sensor velocity, in feet per second

Figure 2. Measured radar unit sensor velocity in relation to measured acoustic Doppler current profiler (ADCP) cross-sectional velocity for the Herring River at the Chequessett Neck Road dike, Wellfleet, Massachusetts, from June 24, 2015, through September 30, 2017.

and stored all measured data. Data were collected at 5-minute intervals and transmitted hourly via cellular-modem systems to the USGS office. All data are archived in the USGS NWIS database (U.S. Geological Survey, 2019).

At the Bound Brook station, a continuously recording water-quality monitor was deployed from May 24, 2016, to June 20, 2017, and at the Pole Dike Creek station a continuously recording water-quality monitor was deployed from May 25, 2016, to May 25, 2017. These monitors measured water temperature, $\mathrm{pH}, \mathrm{SpC}$ (adjusted to $25^{\circ} \mathrm{C}$ ), and $\mathrm{DO}$ (Wagner and others, 2006). The monitoring stations on these tributaries contained structures that housed digital data loggers that recorded and stored all measured data. Data were collected at 5-minute intervals and retrieved on a weekly basis.

USGS personnel visited all three stations monthly to check calibration of instruments, determine whether data shifts were needed, maintain the water-quality monitors, and ensure collection of high-quality data. Data were reviewed for quality assurance and quality control by USGS personnel and subsequently published in the NWIS database (U.S. Geological Survey, 2019).

\section{Collection and Processing of Composite and Discrete Water-Quality Samples}

Collection and processing of composite and discrete water-quality samples followed USGS protocols (U.S. Geological Survey, variously dated). Flow-weighted composite samples were collected because of the strong likelihood of substantial variations in constituent concentrations during individual flood and ebb tides. To illustrate the justification and effectiveness of flow-weighted composite sampling versus discrete sampling, discrete samples were collected by programming an ISCO model 6712 automatic sampler to collect a sample every 30 minutes during four 12-hour periods in February, March, May, and November 2016. This sampling was designed to determine the extent of variation in constituent concentrations over flood and ebb tides. Constituent concentrations varied substantially and generally systematically during tidal cycles. Concentrations reached a maximum at the end of the ebb tide and beginning of the flood tide, then declined rapidly to a minimum at the middle of the incoming 
tide, and then remained near this minimum until the middle of the outgoing tide, when they rapidly increased (fig. 3). Because of this variation in concentration over tidal cycles, discrete grab samples would not be representative of the tidal average concentrations unless numerous samples were collected. Figure 3 illustrates how nutrient $\left(\mathrm{NH}_{4}\right.$, total phosphorus [TP], orthophosphate, and total nitrogen [TN]) concentrations calculated from flow-weighted composite sampling differ from measured individual discrete samples over one sequence of flood followed by ebb tide. Flow-weighted composite sampling in conjunction with continuous discharge computation is the only practical (and economical) way to obtain representative concentrations to be used with regression analysis to obtain fluxes in this highly dynamic system. Orthophosphate was one exception to this general pattern during the February (not shown) and May (fig. 3) samplings, over which concentrations varied much more than during other sequences.

At the Chequessett Neck Road monitoring station, flowproportional composite samples were collected approximately weekly from November 2015 through September 2017. A data logger was programmed to initiate sampling after a fixed volume of water (about 220,000 cubic feet [ $\left.\mathrm{ft}^{3}\right]$ ) flowed past the sampling point during a flood tide. The cumulative volume of water was computed instantaneously from the velocityvelocity and stage-area ratings programmed into the data logger. The program directed the automatic sampler to pump about 100 milliliters $(\mathrm{mL})$ of sample from an inlet near the bottom of the culvert after the initial volume had passed the station. This sample was collected in one of four 3.5-liter (L) sample bottles (flood whole water). Immediately thereafter, a second sample of about $100 \mathrm{~mL}$ was collected and dispensed into a reservoir in the sampler base. A peristaltic pump affixed to the wall of the shelter was activated after the second sample collection to pump that second sample aliquot in the reservoir through a capsule filter and into a second 3.5-L sample bottle (flood filtered water). The automatic sampler was programmed to go through a purge cycle to flush the line after each sample collection. The data logger was programmed to track the cumulative volume flowing past the station, to direct additional sample collection of whole water and filtered water after each successive volume (about 220,000 $\mathrm{ft}^{3}$ ) of water had passed the station, and to composite each of these subsamples into the appropriate 3.5 -L bottles.

When the data logger detected flow reversal (from flood to ebb), it followed the same program to direct pumping of ebb water into the appropriate $3.5-\mathrm{L}$ bottles for whole water and filtered water after each preset volume of water (about $240,000 \mathrm{ft}^{3}$ ) passed the station. The program was designed to sample from two successive complete tidal cycles (that is, two flood and two ebb tides) and generate four composite samples (one flood whole water, one flood filtered, one ebb whole water, and one ebb filtered), over an approximate 24.8-hour period. The sampling routine was designed to collect thirty 100 -mL subsamples in each composite bottle flow-proportionally throughout two flood and two ebb tides during the highest spring tides, when the total volumes of water passing the gage were the highest. Fewer samples were to be collected during neap tides, when the total volume of water was lower, than during spring tides. The sampling was designed to ensure that the largest tides were sampled throughout the tidal cycle and that sufficient sample would be collected on neap tides with the smallest volumes.

Composite samples were retrieved usually within 2 hours of completion of sample collection and were transported to the NPS laboratory for processing. Each composite sample of filtered water was transferred to an 8-L polyethylene churn splitter and separated into bottles for analysis of the following constituents: (i) total dissolved nitrogen (TDN) and total dissolved phosphorus (TDP), (ii) ammonium $\left(\mathrm{NH}_{4}\right.$ ), (iii) nitrate plus nitrite $\left(\mathrm{NO}_{3}+\mathrm{NO}_{2}\right)$, (iv) silica $\left(\mathrm{SiO}_{2}\right)$, and (vi) dissolved organic carbon (DOC). The TN and TP, $\mathrm{NH}_{4}, \mathrm{NO}_{3}+\mathrm{NO}_{2}$, and $\mathrm{SiO}_{2}$ samples were stored in opaque 125 -mL polyethylene bottles in a freezer. The DOC subsample was collected in a prebaked 40-mL amber vial, acidified with 190 microliters of 20-percent hydrochloric acid, and stored in a refrigerator. Each composite unfiltered (whole water) sample was transferred into an 8-L polyethylene churn splitter and separated into bottles for the analysis of following constituents: TN and TP. The TN and TP samples were stored in $125-\mathrm{mL}$ polyethylene bottles in a freezer.

At the Bound Brook and Pole Dike Creek monitoring stations, v-notch weir plates were installed to channelize the flow so that it could be quantified by continuous measurements of stage. However, leakage around the weir plates during substantial periods made it impossible to quantify flow continuously in these tributaries. ISCO model 2700 automated samplers were programmed to initiate sample collection once every 10 days. At Bound Brook samples were collected from June 2016 to June 2017, and at Pole Dike Creek samples were collected from July 2016 to June 2017. Initially at Bound Brook and at Pole Dike Creek, the programs directed the automatic samplers to collect approximately $800-\mathrm{mL}$ samples once per hour after a preprogrammed threshold volume of water had passed the station. At Pole Dike Creek, the threshold discharge volume was 12,000 $\mathrm{ft}^{3}$, and the threshold at Bound Brook was $3,000 \mathrm{ft}^{3}$. In September 2016, leakage around and under the v-notch weir plates was observed at Bound Brook and Pole Dike Creek. Because this leakage resulted in inaccurate flow computation, in September 2016 the sampler at Bound Brook was reprogrammed to collect a time-weighted composite sample by collecting a subsample every hour for a 24-hour period. Flow is tidal (alternating between flood and ebb) at the Pole Dike Creek station but is not tidal at Bound Brook. At Pole Dike Creek, the tide is asymmetric: on average, water flows in for about 4.2 hours and out for about 8.2 hours during each tidal cycle. Therefore, at Pole Dike Creek the samples represent either flood or ebb flow, whereas at Bound Brook all samples represent ebb flow. Sampling continued until 24 hours had elapsed, resulting in a maximum of 24 samples. At the Pole Dike Creek location, the sampler was reprogramed to collect a sample every hour for a 24 -hour period. Hourly samples were combined for all samples during ebb and flood tides 


\section{EXPLANATION}

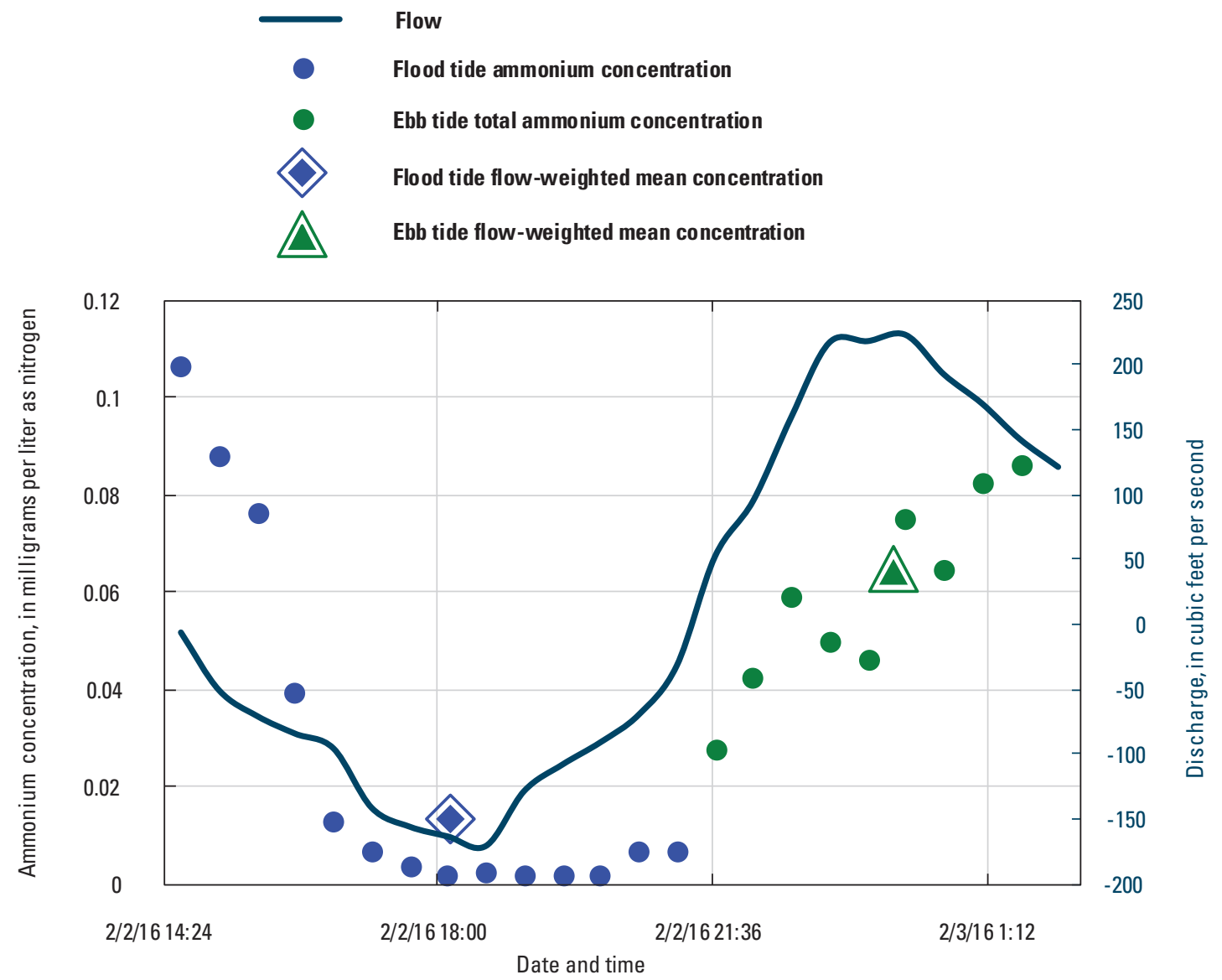

Figure 3. Discharge (in cubic feet per second), measured nutrient concentrations for discrete samples, and calculated flow-weighted composite concentrations for the flood and ebb tides, Herring River at Chequessett Neck Road in Wellfleet, Massachusetts, 2016. $A$, ammonium, $B$, total phosphorus, $C$, orthophosphate, and $D$, total nitrogen. Negative discharge indicates flood tide, and positive discharge indicates ebb tide. 

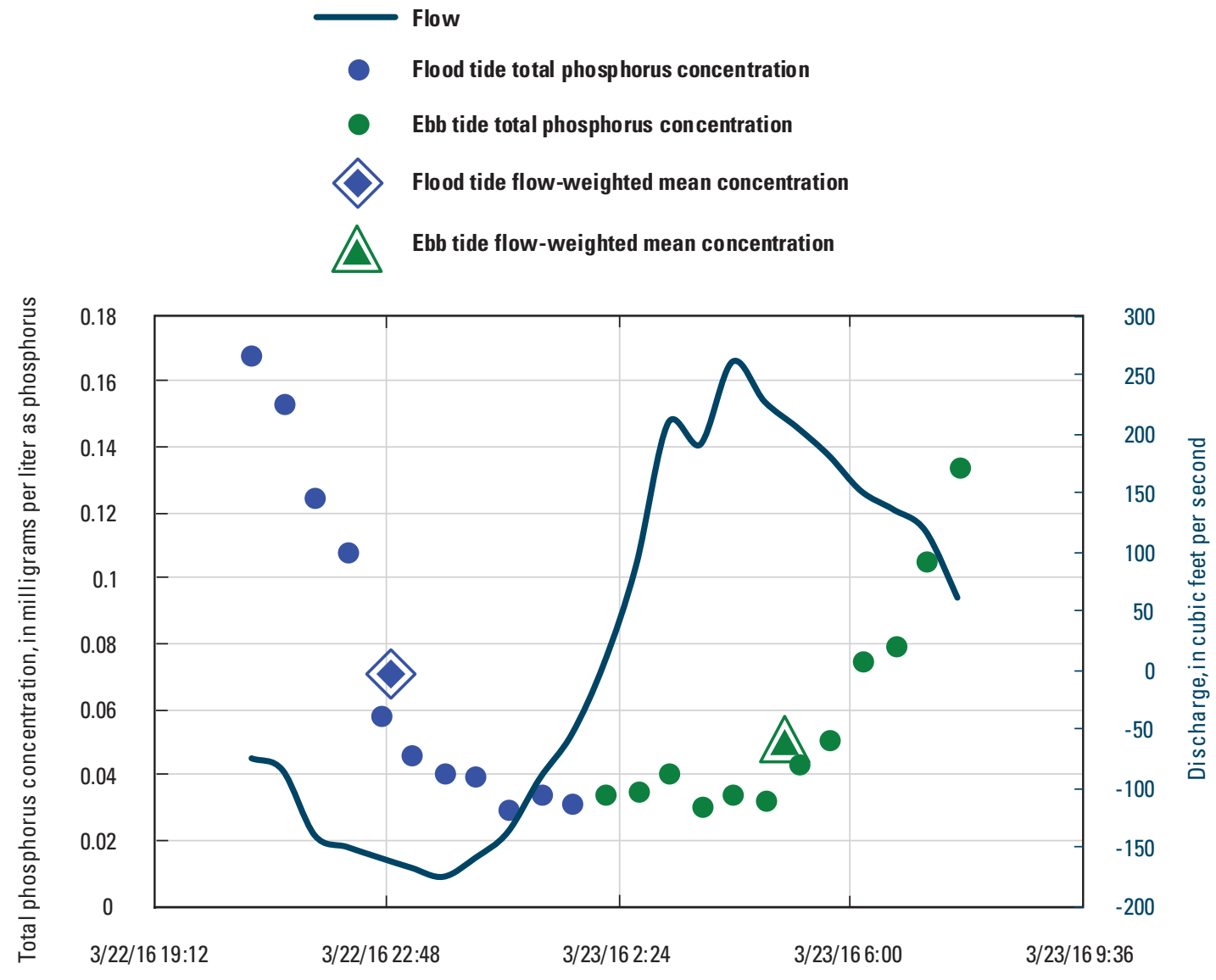

Date and time

Figure 3.-Continued 

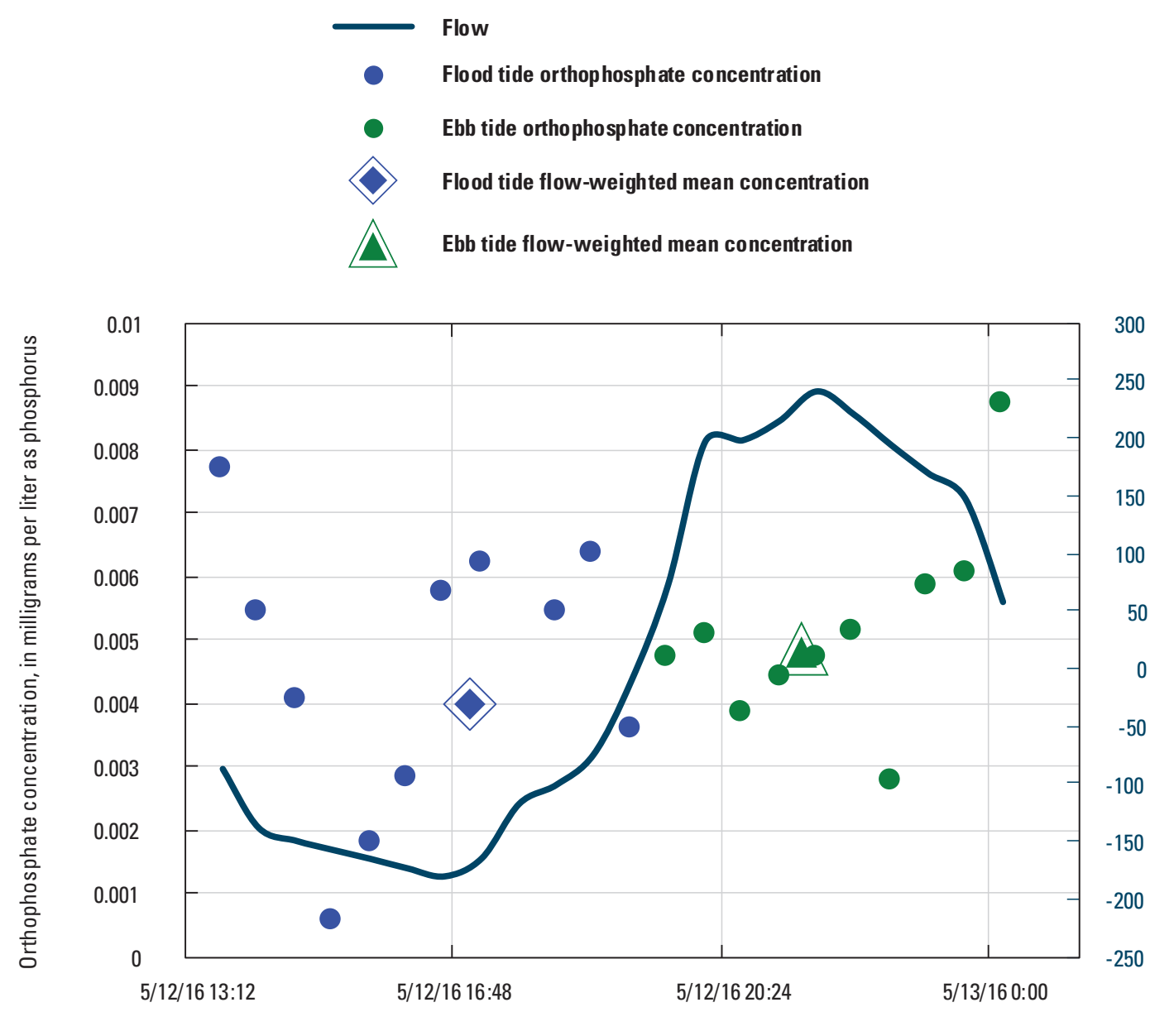

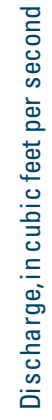

Figure 3.-Continued 


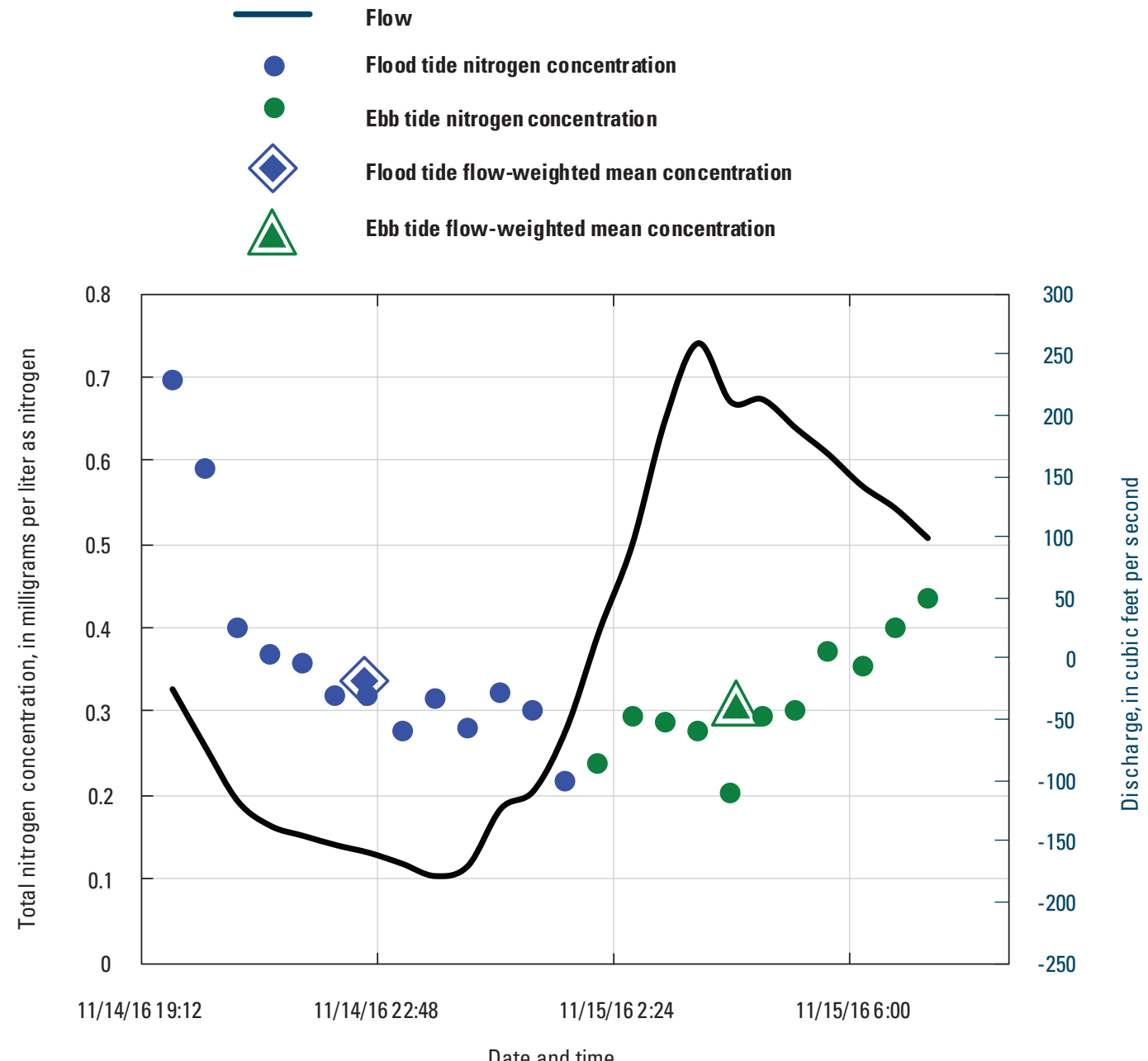

Figure 3.-Continued

separately to generate time-weighted samples. The magnitude of leakage prohibited quantifying flow but was small enough that the program for volume-controlled sampling in the early part of the record was deemed satisfactory.

Upon completion of the 24-hour sampling period, the samples were transported to the NPS laboratory for processing. Individual samples were composited in an 8-L churn as flood or ebb (that is, two composite samples) for Pole Dike Creek or entirely as ebb (one composite sample) for Bound Brook. If the total composite sample volume was greater than the capacity of the churn (as occasionally happened at Bound Brook), the samples were subsampled proportionately to attain a final composite that was representative of all of the sample volume in the automatic sampler bottles. The churn was used to obtain three separate samples for TN and TP, total iron, and DOC. The DOC subsample was filtered through a 0.45 -micrometer $(\mu \mathrm{m})$ filter and stored chilled in an amber glass bottle. All other samples were stored in polyethylene bottles and refrigerated until analysis.

\section{Quality Assurance/Quality Control on Composite Sampling}

Eight field blank sampling routines were conducted during the sampling period (November 2015-September 2017). Field blank samples were prepared by directing the sampler to collect two $100-\mathrm{mL}$ samples from a carboy of deionized water in the shelter at the monitoring station every hour for 24 hours through the same tubing used for environmental (ENV) samples. One of the samples from each hourly collection was subsequently filtered through a $0.45-\mu \mathrm{m}$ capsule filter and composited in one bottle, and the other sample was composited unfiltered. Except for the inlet tubing that connects the automatic sampler to the stream intake, the blank samples interacted with the same equipment and tubing as the ENV samples. Replicate samples were collected intermittently by collecting another bottle set from the churn splitter during sample processing of ENV samples. 
Isokinetic equal width increment (EWI) samples were collected manually immediately upstream from the box culvert(s) during flood tides and immediately downstream from the three box culverts during ebb tides following standard protocols (U.S. Geological Survey, variously dated). The automated sampler was triggered to collect a sample from the single intake point in one culvert (where routine ENV composite samples were collected) concurrently to test whether samples collected at a single point were representative of the entire cross section (vertically and horizontally). Concurrent EWI and automated sampler point samples were collected on April 19, 2017, and September 13, 2017, over one flood and one ebb tide. The individual samples were composited and processed in the same way as the ENV samples.

\section{Analytical Methods and Quality Assurance}

Concentrations of TDN, TDP, silica, orthophosphate, TN, and TP were analyzed at the Center for Coastal Studies Laboratory in Provincetown, Mass. Concentrations of dissolved and total iron were analyzed at the NPS laboratory in Truro, Mass., from November 2015 to May 2017 and at the Center for Coastal Studies Laboratory in Provincetown, Mass., from June 2017 through September 2017. The laboratories used identical methods of analysis. DOC was analyzed at the Woods Hole Oceanographic Institution Dissolved Carbon Isotope Laboratory in Woods Hole, Mass.
The analytical methods used for water-quality analysis, USGS parameter codes, method references, and minimum detection limits for samples collected at water-qualitymonitoring stations on the Herring River are summarized in table 2.

Laboratory quality assurance (QA) protocols included the analysis of standard reference materials, field replicates, field blanks, and laboratory blanks. All water-quality data are published in Huntington and Spaetzel (2020).

Laboratory analyses of standard reference materials for nutrients and DOC consistently met the data quality objectives (DQOs) established for this study. The DQOs were relative percent differences (RPDs) of $<20$ percent. Analysis of field replicate samples shows that median RPD values between the replicates and the corresponding ENV samples for all constituents were usually substantially less than the DQOs of \pm 20 percent.

Results for field blanks indicated that for nutrients, in most cases the blank analyte concentrations were substantially lower than the lowest ENV sample and lower than or similar to the minimum detection limit, except for concentrations of $\mathrm{NH}_{4}$. Analyses of laboratory-prepared deionized water blanks showed that there was no detectable contamination of samples within the laboratory for any constituent.

The median value for $\mathrm{NH}_{4}$ in the field blanks was 0.008 milligram per liter $(\mathrm{mg} / \mathrm{L})$ as nitrogen $(\mathrm{N})$, which was equivalent to or higher than 10 percent of the ENV samples on the ebb tide and 25 percent of the ENV samples on the

Table 2. Summary of water-quality laboratory analytical methods, U.S. Geological Survey parameter codes, method references, and minimum detection limits for samples collected at water-quality-monitoring stations on the Herring River, Wellfleet, Massachusetts.

[USGS, U.S. Geological Survey; mg/L, milligram per liter; N, nitrogen; P, phosphorus; C, carbon; ${ }^{\circ} \mathrm{C}$, degree Celsius]

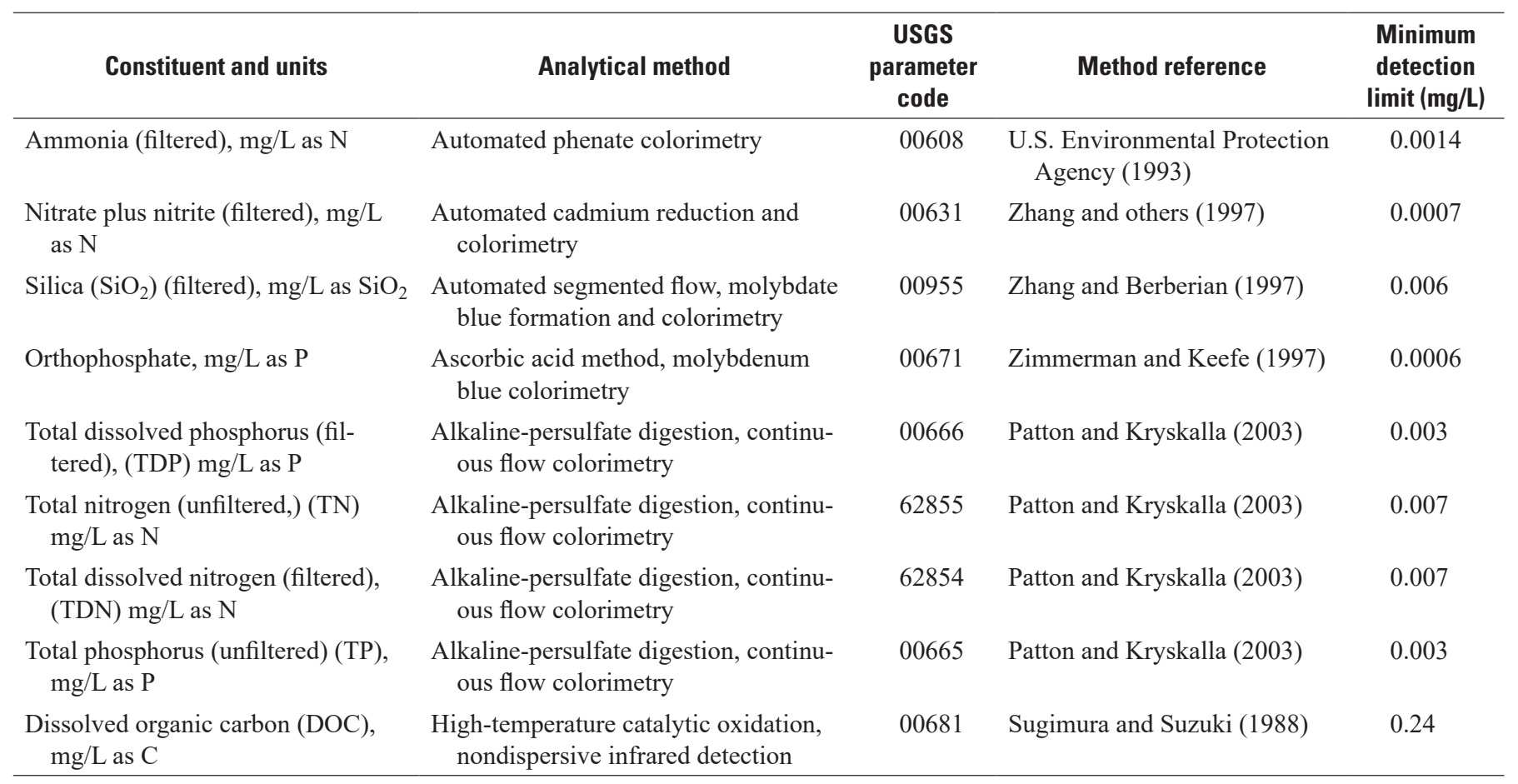


flood tide. Ammonium concentrations in field blank samples may have been elevated because of gaseous diffusion from the atmosphere into open containers during the collection of composite samples. The possibility of contamination from the atmosphere was investigated during this study. A 3.5-L Nalgene bottle (the same kind used in the ISCO sampler base for collection of composite samples) filled with deionized water was left in the sampling shelter for 25 hours covered loosely with plastic. A second sample bottle filled with deionized water was left sealed in the shelter for 25 hours. Both samples were analyzed for $\mathrm{NH}_{4}$ before and after being exposed to the churn. Ammonium was detected at levels above the minimum reporting limit and above the lowest ENV samples in the samples exposed to the atmosphere for 25 hours in the shelter but not detected in the samples in sealed bottles. The contamination occurred almost entirely during the period of exposure in the shelter and not during the churn-splitting process.

Results of the comparison between samples collected by EWI and the automated sampler were variable. The data from these analyses generally met a DQO of $<20$ percent RPD for certain analytes (TN, TP, orthophosphate, $\mathrm{NO}_{3}+\mathrm{NO}_{2}$, and silicate), but the RPD was $>20$ percent for other analytes $\left(\mathrm{NH}_{4}\right.$ and TDP). The RPD for $\mathrm{NH}_{4}$ was in the range of 35 to 65 percent, and the RPD for TDP was in the range of $<10$ percent to 87 percent. The results of this comparison indicate that, for certain constituents, the automated point-sampling is not fully representative of the water in the cross section and introduces some error.

On September 6, 2018, field measurements were taken to test whether the water-quality monitor installed on the marsh side of the Chequessett Neck Road dike recorded water-quality parameters that were representative of total flow through the culverts. The monitor was installed such that the probes were submersed even during the lowest flow conditions; therefore, they were positioned within a few centimeters from the bottom of the culvert, immediately outside of the box culvert. Two monitors were attached to a B-reel assembly above a 150-pound weight and suspended in the flow during one ebb tide. Over the course of a complete ebb tide, the mobile monitors were positioned at different vertical and horizontal positions in the culvert where the fixed monitor was deployed and in the middle culvert. The objective was to determine whether the water was well mixed vertically within a given culvert and horizontally between culverts. During the ebb tide, there was a small but consistent bias in $\mathrm{SpC}$, whereby the fixed monitor, which was located near the floor of the culvert, had a higher $\mathrm{SpC}$ than was measured in the water column above the floor of the culvert regardless of where in the water column vertically or horizontally the mobile monitors were positioned. The percentage difference varied by time in the ebb tide. Measurements of $\mathrm{SpC}$ by the mobile monitors in the water column above the fixed monitor were 2.4, 8.3, 4.9, and 5.1 percent lower in the first 1.4 hours, 1.4 to 2.8 hours, 2.8 to 5.3 hours, and 5.3 to 5.8 hours, respectively. This bias is likely a result of a density stratification whereby fresher water (tidal inflow mixed with river outflow) overlaid saltier water that had not mixed as thoroughly with freshwater. Comparable profiles were not measured on a flood tide, but because of the volume of water seaward of the dike and higher tidal amplitudes than landward of the dike, it is likely that the flood tide was better mixed (less stratified) than the ebb tide. There were no appreciable differences in water temperature among the monitors throughout the ebb tide. The mobile monitors were similar to each other in dissolved oxygen (DO) measurements, which were on average about $1.5 \mathrm{mg} / \mathrm{L}$ of DO (14 percent) less than DO recorded by the fixed monitor. The mobile monitors were similar to each other in $\mathrm{pH}$ measurements, which were about one- to two-tenths higher than $\mathrm{pH}$ recorded by the fixed monitor for the first 5 hours of the ebb tide; after that, and for the duration of that ebb tide, they recorded progressively increasing $\mathrm{pH}$ (from 8 to 8.4), whereas the fixed monitor recorded a nearly constant $\mathrm{pH}$ between 7.8 and 7.9. The reason for the $\mathrm{pH}$ divergence late in the ebb tide is not known.

\section{Modeling Nutrient Fluxes Across the Ocean-Estuary Boundary With LOADEST}

The LOADEST regression model (Runkel and others, 2004) was used to compute nutrient fluxes across the oceanestuary boundary. Separate models were developed for each nutrient and for ebb and flood tides separately. This approach treats the bidirectional flow past the dike as if there were two separate rivers, one flowing in for part of a day and one flowing out for part of a day. In this application, constituent concentration was determined for flow-weighted composite samples that each represented two consecutive flood or two consecutive ebb tides. Two consecutive flood tides cover an average period of about 19.6 hours, and two consecutive ebb tides cover a partially overlapping period of about 17.6 hours. These two consecutive flood and ebb tides are equal to a tidal day of about 24.8 hours, consistent with what Garrett (1972) reported for this region. For this LOADEST application, we used a "tidal day" rather than a calendar day. A tidal day was defined as the total amount of water flowing past the gage in two successive flood or ebb tides, and the day was assigned the date on which most of the flow occurred. The composite sample for that period represented the nutrient concentration for that tidal day. Since the average length of a tidal day was about 24.8 hours, this results in an overestimation bias of the daily loads of 3.3 percent.

The LOADEST model uses pairs of concentration and discharge data to calibrate the adjusted maximum likelihood estimate (AMLE) (Cohn, 1988; Cohn and others, 1992) regression between constituent load, streamflow, and seasonality. AMLE was used because some of the datasets contain censored data (below the minimum detection level), and AMLE results in a nearly unbiased estimate of load (Cohn, 1988). LOADEST determines the "best" regression model based on the Akaike information criterion. The resulting regression models can be used to estimate loads over user-specified time intervals. 
LOADEST model output includes estimates of daily nutrient load (kilograms per day) and regression statistics that include correlation, mean load estimates, 95-percent confidence intervals, standard error, and bias diagnostics for estimates of load and concentration. Descriptions of the bias diagnostics were included in model updates in 2013 (Runkel, 2013). Bias diagnostics include load bias in percent $\left(B_{p}\right)$; partial load ratio $(P L R)$, which is equal to the sum of the estimated loads divided by the sum of the observed loads; partial concentration ratio $(P C R)$; and the Nash-Sutcliffe efficiency index $(E)$. Values of $P L R>1.0$ indicate positive load bias (estimated loads exceed measured loads), and $P L R$ values $<1.0$ indicate negative load bias. Runkel (2013) provides the following guidance: (i) model should not be used if $B_{p}>25$ percent; and (ii) $E$ ranges from negative infinity to 1, where 1 indicates a perfect fit to the observed data, 0 indicates that the model estimates are as accurate as the mean of observed data, and $E<0$ indicates that the observed mean is a better estimate than the model estimates. The bias statistics for each model are reported in appendix 1. LOADEST regression models from Runkel and others (2004) that were used in this study are listed in table 2.1 (app. 2). The coefficients for each constituent's regression model on flood and ebb tides are listed in table 2.2 (app. 2).

Only in the case of $\mathrm{NH}_{4}$ on the ebb tide was $B_{p}>25$ percent, and in that instance, we did not use the LOADEST model for computation of loads. The $P L R$ values were all close to 1 , indicating little appreciable positive or negative load bias. The Nash-Sutcliffe efficiency index indicated that, except for $\mathrm{NH}_{4}$ on the ebb tide, the model provided better estimates of the observed data.

The LOADEST model assumes that the residuals are independent and homoscedastic (having constant variance; Runkel and others, 2004). This assumption was investigated and validated by plotting model residuals in relation to load. The plots are not presented in this report or the accompanying data release; however, the data used for plotting are reported in the data release (Huntington and Spaetzel, 2020). For most constituents on ebb and flood tides, these plots showed a random distribution with both positive and negative values without any clear patterns or trends and therefore were consistent with the assumption that the residuals were independent and homoscedastic. One exception was for DOC on the ebb tide, where there was a trend towards increasing variance with increasing DOC load but no trend in the sign of the bias. The only other exception was for TDP on the flood tide, where there was evidence of positive bias when TDP loads were low and somewhat more positive bias when TDP loads were high. In these two cases, the model assumptions are not fully met; therefore, there is greater uncertainty in estimated loads. The model also assumes that the residuals are normally distributed, and this assumption was investigated by plotting model residuals in relation to the normal quantile (Z-score). The linearity of these plots suggests that the residuals follow a normal distribution. The LOADEST model can be subject to a seasonal bias due to the model's fixed shape of the concentration-discharge relation among seasons, when in reality the shape may be different (Hirsch, 2014). We tested for seasonal bias by plotting the seasonal distribution of residuals in boxplots as described in Hirsch (2014). Throughout this report, the seasons are defined as spring (March through May), summer (June through August), fall (September through November), and winter (December through February). Where results are expressed on an annual basis, the period is described as a calendar year (January through December). In this type of plot, periods where the model may be biased due to the fixed shape of the seasonally varying concentration discharge relation can be identified. Although there is some evidence for moderate seasonal variation in bias, generally we found little evidence for substantial bias. The largest seasonal biases were in the fall, when there were fewer samples. In the fall, there were moderately high positive biases for silica, nitrate, and DOC on the ebb tide and negative biases for TP, TN, and TDP on the flood tide.

The nonparametric Kendall's rank correlation test was used to test for the statistical significance of correlations between 7-day antecedent rainfall and constituent concentrations by using S-PLUS software. If calculated $p$-values were $>0.05$, then the correlations were judged to be not significant.

\section{Results}

The following sections present the results of the analyses described in the methods sections of this report. The first five sections describe results of the discharge and water-quality data analyzed at the Herring River at Chequessett Neck Road in Wellfleet, Mass. The first section describes the discharge computed for the Herring River during the study period and compares these results to other studies' estimates for this site. The second section describes the air temperature, water temperature, and precipitation time series. The third section describes the continuous $\mathrm{DO}, \mathrm{SpC}, \mathrm{pH}$, gage height, and streamwater velocity time series. The fourth section describes the seasonal variation in nutrient concentrations. The fifth section describes the estimated nutrient fluxes across the oceanestuary boundary. The sixth and seventh sections describe variations in $\mathrm{DO}, \mathrm{pH}, \mathrm{SpC}$, water temperature and nutrient concentrations at the Pole Dike Creek and Bound Brook tributaries.

\section{Discharge}

Tidal daily Herring River discharge (two consecutive flood, ebb, and river [ebb minus flood]) flows indicate substantial daily, seasonal, and interannual variation (fig. 4). Mean tidal daily discharges during the period from November 2015 to September 2017 were 66.9, 69.0, and 2.11 cubic feet per second $(\mathrm{ft} 3 / \mathrm{s})$ for the flood, ebb, and river flows, respectively. The variation in tidal daily discharge was associated with the differences between spring and neap tides and with differences 


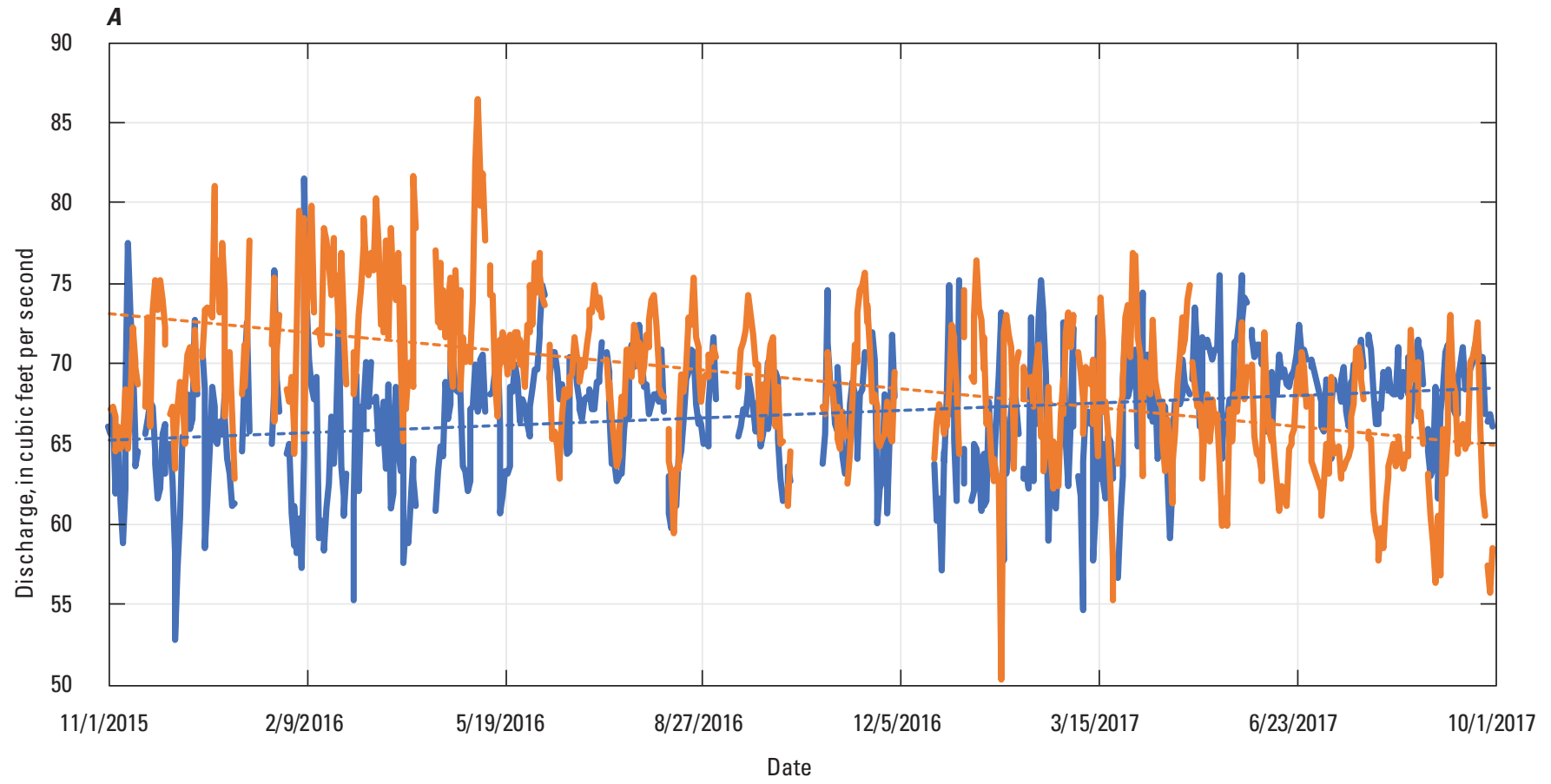

EXPLANATION

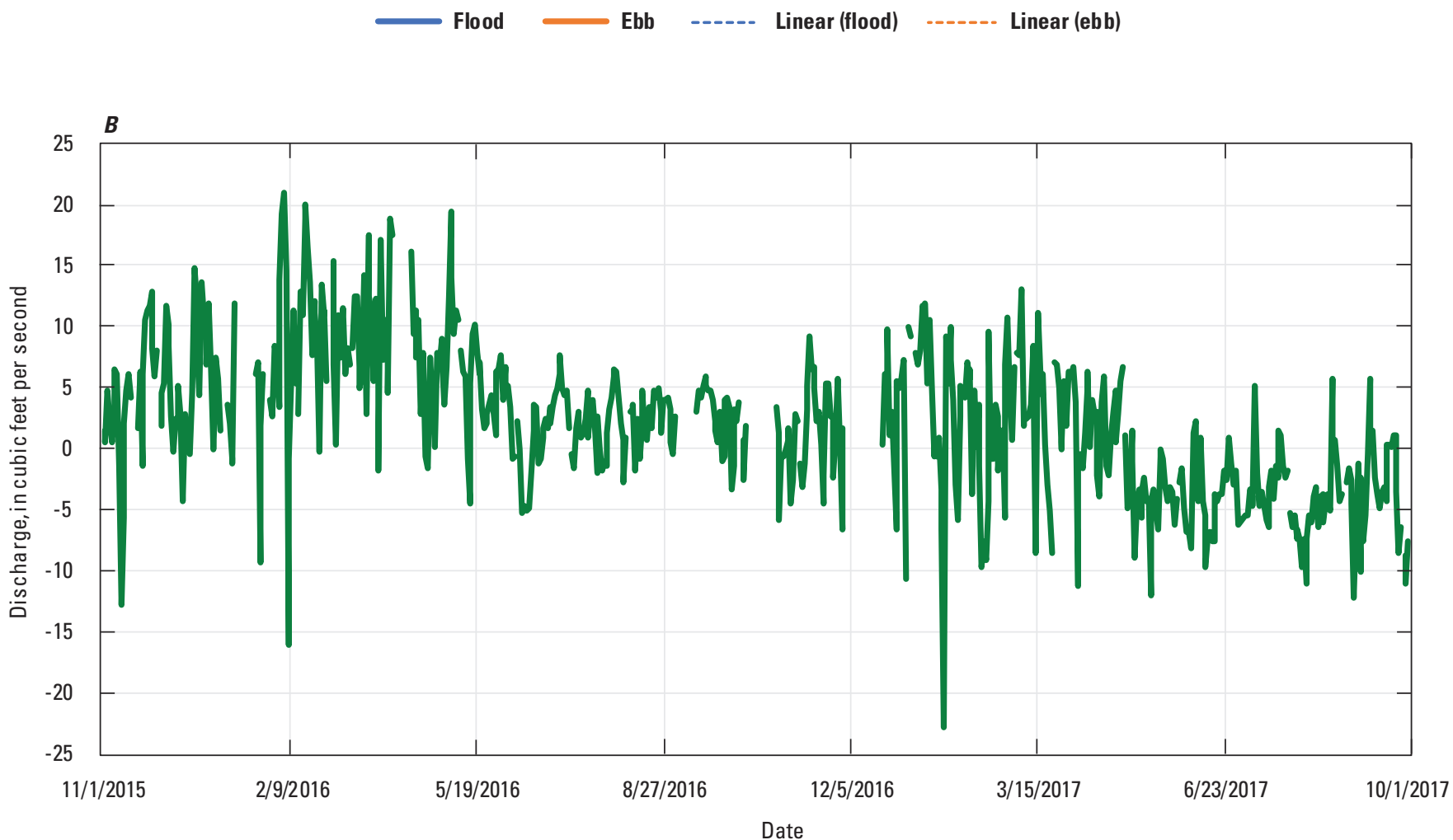

EXPLANATION

Herring River (ebb minus flood)

Figure 4. Computed mean discharge rates for tidal days for the Herring River at Chequessett Neck Road in Wellfleet, Massachusetts, from November 2015 through September 2017. A, Computed mean flood and ebb discharge rates. B, Computed mean Herring River discharge (calculated as ebb minus flood). Tidal days are two consecutive flood or two consecutive ebb tides. The day associated with these mean discharge values is the day where most of the flow occurred. 
in freshwater runoff. Ebb flows were consistently higher than flood flows from November 2015 through January 2017, as expected given the contribution of freshwater flow from the Herring River to the ebb flow. From the end of March in 2017 to the end of the study in September 2017, flood flows usually exceeded ebb flows, as illustrated in figure $4(A$ and $B)$, which shows generally negative Herring River freshwater discharge.

The long-term average difference between flood and ebb flows during the period of discharge record (June 25, 2015, through September 30,2017), which is interpreted as the river freshwater component of the ebb flow, was substantially lower than previous estimates in other studies of the Herring River (Garvine, 1987; Roman and others, 1995). We estimate the average rate of Herring River discharge during the period of study to be $2.11 \mathrm{ft} 3 / \mathrm{s}$ ( 0.060 cubic meter per second [ $\left.\left.\mathrm{m}^{3} / \mathrm{s}\right]\right)$. The total annual precipitation in 2016 was $102 \mathrm{~cm}$, and from January through September in 2017, the total was $108 \mathrm{~cm}$. Previous studies of the Herring River have used alternative methods to estimate river discharge that did not involve physical measurements of discharge, as were made in this study, and these alternative methods resulted in much higher estimates of river discharge. Masterson (2004) estimated a value of $0.33 \mathrm{~m} 3 / \mathrm{s}$ by using a numerical groundwater model and on the basis of average annual precipitation of $107 \mathrm{~cm}$ per year, assuming that 55 percent of precipitation reached the aquifer as recharge. Garvine (1987) and Roman and others (1995) used an estimate of $0.25 \mathrm{~m}^{3} / \mathrm{s}$ in their hydraulic modeling studies for the Herring River. According to another approach, which assumed the groundwater recharge on Cape Cod to be about 45 percent of total annual precipitation (LeBlanc and others, 1986), the groundwater-contributing drainage area to be about $19.1 \mathrm{~km}^{2}$ (Carlson and others, 2017a, b), the average annual precipitation to be $121 \mathrm{~cm}$, and the surface-water runoff to be negligible, the average annual runoff for the Herring River was estimated to be $0.33 \mathrm{~m}^{3} / \mathrm{s}$.

The estimated water yield for the Herring River in Wellfleet from November 2015 to September 2017 was 0.19 cubic feet per second per square mile, based on a mean discharge of $2.11 \mathrm{ft} 3 / \mathrm{s}\left(0.06 \mathrm{~m}^{3} / \mathrm{s}\right)$ and surface water contributing area of 11.0 square miles. This estimate is lower than the water yields for four other small rivers on or near Cape Cod for the same period (table 3). Flow on these other rivers is affected by various factors, including the groundwateror surface-water-contributing areas. The various rivers are affected in different ways, and the contributing areas are not well known, so these comparisons are shown only for general context and not for a quantitative comparison. In summary, the computed Herring River discharge is lower than values estimated by other studies for this river and in comparisons with other rivers on or near Cape Cod. The water yields shown in table 3 were computed using surface-water-contributing areas. The differences among rivers could be due in part to differences in groundwater-contributing areas that are poorly quantified. The differences between these other rivers and the Herring River could also be related to the uncertainties in discharge for both the flood and ebb tides.

Computed daily mean discharge rates were lower in summer months, consistent with higher rates of evapotranspiration (fig. 5). Unexpectedly, there appeared to be an inverse relation between monthly precipitation and monthly mean ebb tidal discharge (fig. 5). In the summer months (June through August), monthly mean discharge at Herring River was $69.8 \mathrm{ft} 3 / \mathrm{s}$ in 2016 and $64.8 \mathrm{ft} 3 / \mathrm{s}$ in 2017 , but total precipitation in Truro during these same summer months was $9.5 \mathrm{~cm}$

Table 3. Watershed contributing areas, average discharge, and associated rate of streamflow of U.S. Geological Survey streamgages on or near Cape Cod, Massachusetts, from November 1, 2015, to September 30, 2017.

[USGS, U.S. Geological Survey; $\mathrm{mi}^{2}$, square mile; $\mathrm{ft} 3 / \mathrm{s}$, cubic foot per second; (ft3 $\left.3 / \mathrm{s}\right) / \mathrm{mi}^{2}$, cubic foot per second per square mile; MA, Massachusetts]

\begin{tabular}{|c|c|c|c|c|}
\hline USGS station name & $\begin{array}{l}\text { USGS station } \\
\text { identification number }\end{array}$ & $\begin{array}{c}\text { Contributing } \\
\text { area } \\
\left(\mathrm{mi}^{2}\right)\end{array}$ & $\begin{array}{l}\text { Average } \\
\text { discharge } \\
\left(\mathrm{ft}^{3} / \mathrm{s}\right)\end{array}$ & $\begin{array}{l}\text { Average rate of } \\
\text { streamflow } \\
\left(\left[\mathrm{ft}^{3} / \mathrm{s}\right] / \mathrm{mi}^{2}\right)\end{array}$ \\
\hline Herring River at Chequessett Neck Road at Wellfleet, MA ${ }^{1}$ & 011058798 & 11.0 & 2.11 & 0.19 \\
\hline Herring River, at North Harwich, $\mathrm{MA}^{2}$ & 01105880 & 9.4 & 8.53 & 0.91 \\
\hline Eel River at Route $3 \mathrm{~A}$ near Plymouth, $\mathrm{MA}^{3}$ & 01105876 & 14.7 & 30.01 & 2.04 \\
\hline Jones River at Kingston, $\mathrm{MA}^{4}$ & 01105870 & 15.7 & 25.55 & 1.29 \\
\hline
\end{tabular}

1 This stream drains from a groundwater basin that is smaller than the surface-water basin.

${ }^{2}$ Occasional regulation by cranberry bog upstream. This stream drains from a groundwater-contributing area that is larger than, and not coincident with, the surface-water basin.

3Flow affected by upstream withdrawals for municipal water supplies. Stage may be affected by occasional high tidal surges.

${ }^{4}$ Flow regulated by pond upstream. Flow affected at times by wastage from Silver Lake. Surface flow may be affected by groundwater that enters from or moves into adjacent basins. Occasional backwater from tidal surge.

5Flow at times includes overflow and leakage from Johns Pond. Occasional regulation by cranberry bog upstream and occasional backwater from tidal surge. 


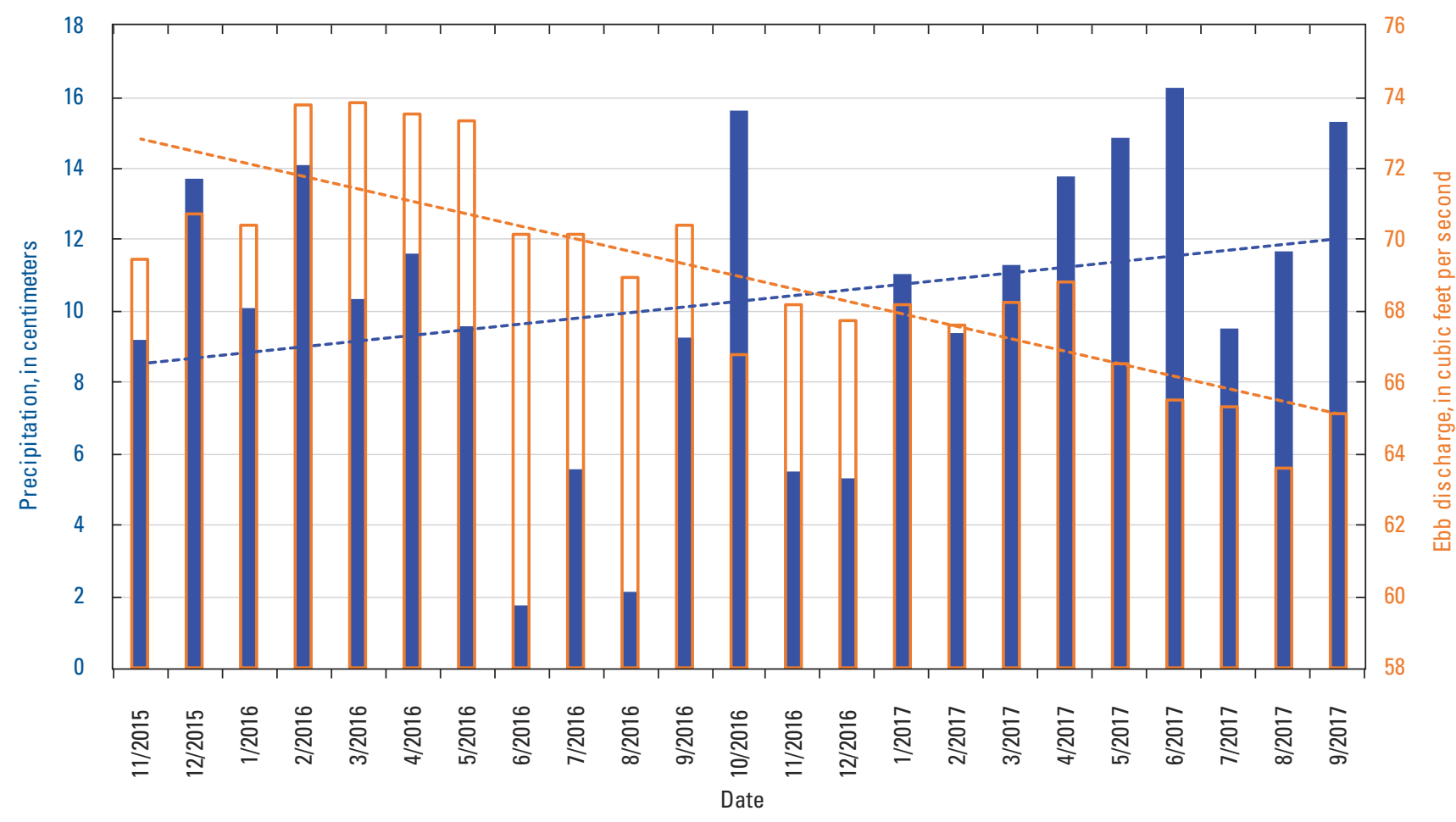

\section{EXPLANATION}

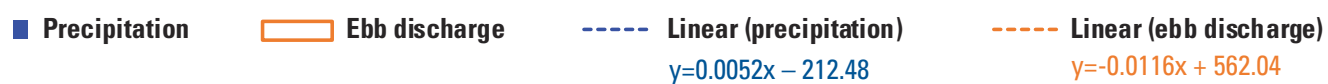

Figure 5. Monthly precipitation in Truro, Massachusetts, and estimated daily mean ebb tide discharge for each month for the Herring River at Chequessett Neck Road in Wellfleet, Mass., from November 2015 through September 2017.

and $37.5 \mathrm{~cm}$, respectively. Monthly mean discharge during the summer months (June through August) of 2017 was $9.6 \mathrm{ft} 3 / \mathrm{s}$ at the Herring River near Harwich, Mass. (USGS station 01105880), which is 16 miles south of the Herring River at Chequessett Neck Road in Wellfleet, Mass., streamgage (USGS station 011058798), and was $6.0 \mathrm{ft} 3 / \mathrm{s}$ during the same summer months of 2016.

Slightly greater monthly mean discharge in the summer of 2016 than in 2017 for the Herring River is somewhat counterintuitive given higher total precipitation in the summer of 2017 than 2016, but the Herring River is a groundwaterdominated system, and groundwater levels may have been substantially higher at the beginning of 2016 than at the beginning of 2017. There may also be substantial lag time between precipitation and groundwater discharge into the Herring River and tributaries. In the spring and early summer of 2016, the groundwater levels were slightly higher (about $25 \mathrm{~cm}$ ) than during the same period in 2017 at the nearby USGS groundwater-level monitoring well (USGS 415353069585401 , MA-WNW 17, Wellfleet, Mass.), which may have resulted in slightly higher groundwater discharge rates in the summer months of 2016 than in 2017.

\section{Air Temperature, Water Temperature, and Precipitation Measurements}

Air temperature varied from about $-10{ }^{\circ} \mathrm{C}$ on the coldest days in winter to about $26^{\circ} \mathrm{C}$ on the warmest days in summer (fig. 6). Water temperature varied from just below $0{ }^{\circ} \mathrm{C}$ in winter to about $27^{\circ} \mathrm{C}$ in summer. The average water temperature in the Herring River at Chequessett Neck Road during July and August in 2016 was $25.5^{\circ} \mathrm{C}$, and in 2017 it was $23.8^{\circ} \mathrm{C}$. Summer air temperatures were somewhat higher in 2016 than in 2017. Water temperature in the Herring River on the river side of the dike at Chequessett Neck Road tracked air temperature closely but with a substantially narrower range in day-to-day variability. The frequency of precipitation events and daily precipitation amounts varied throughout the study period (fig. 7). The biggest difference between years was the comparatively low amount of precipitation in June, July, and August in 2016 and the comparatively high amount of precipitation in May, June, and October in 2017. In 2016, the cumulative precipitation in June, July, and August at Truro, Mass., was $9.5 \mathrm{~cm}$, and in 2017 the cumulative precipitation was $37.5 \mathrm{~cm}$. These differences between years were especially evident in comparison with the longer term (1982 to 2017) average monthly precipitation at this location (fig. 7). 


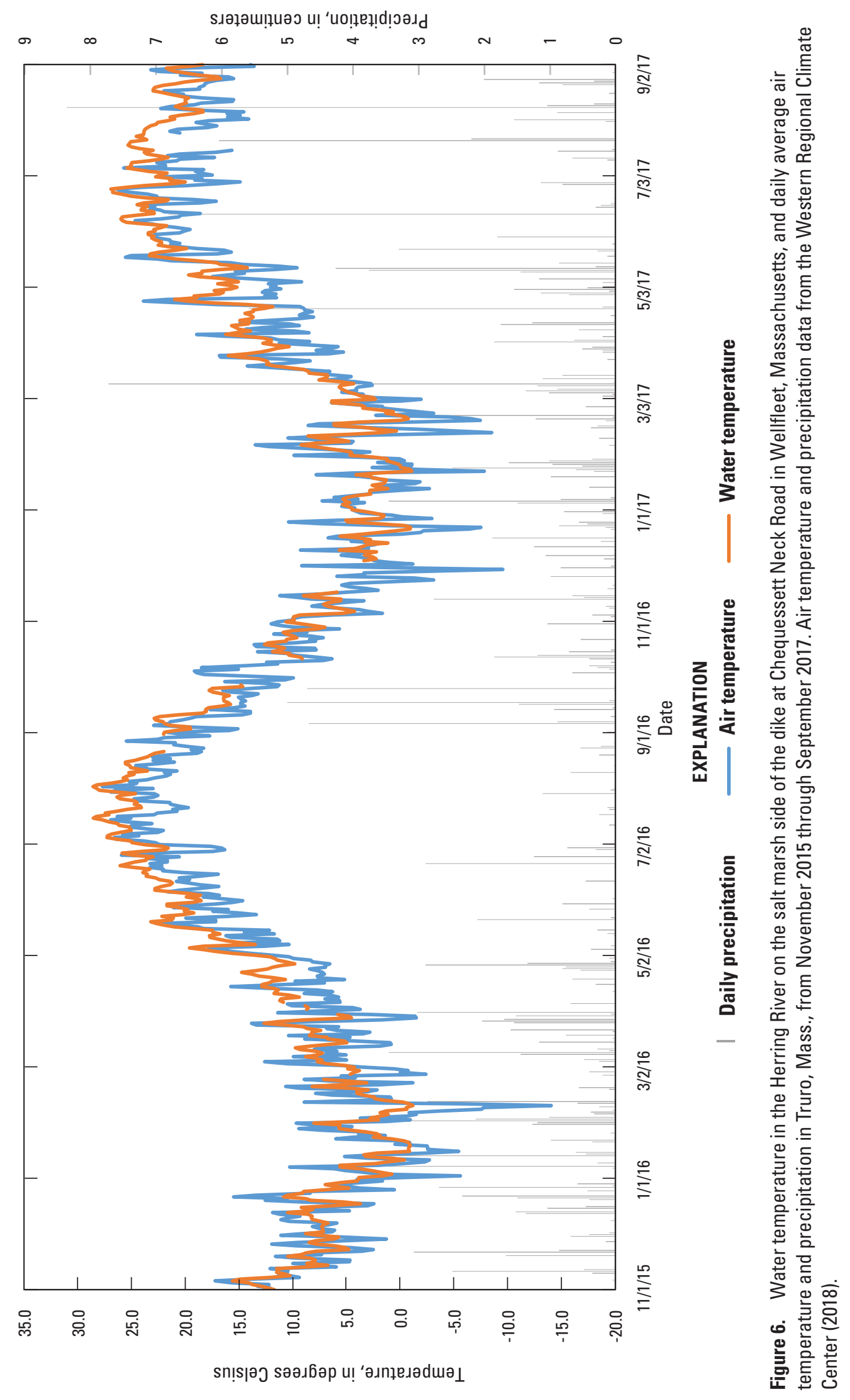




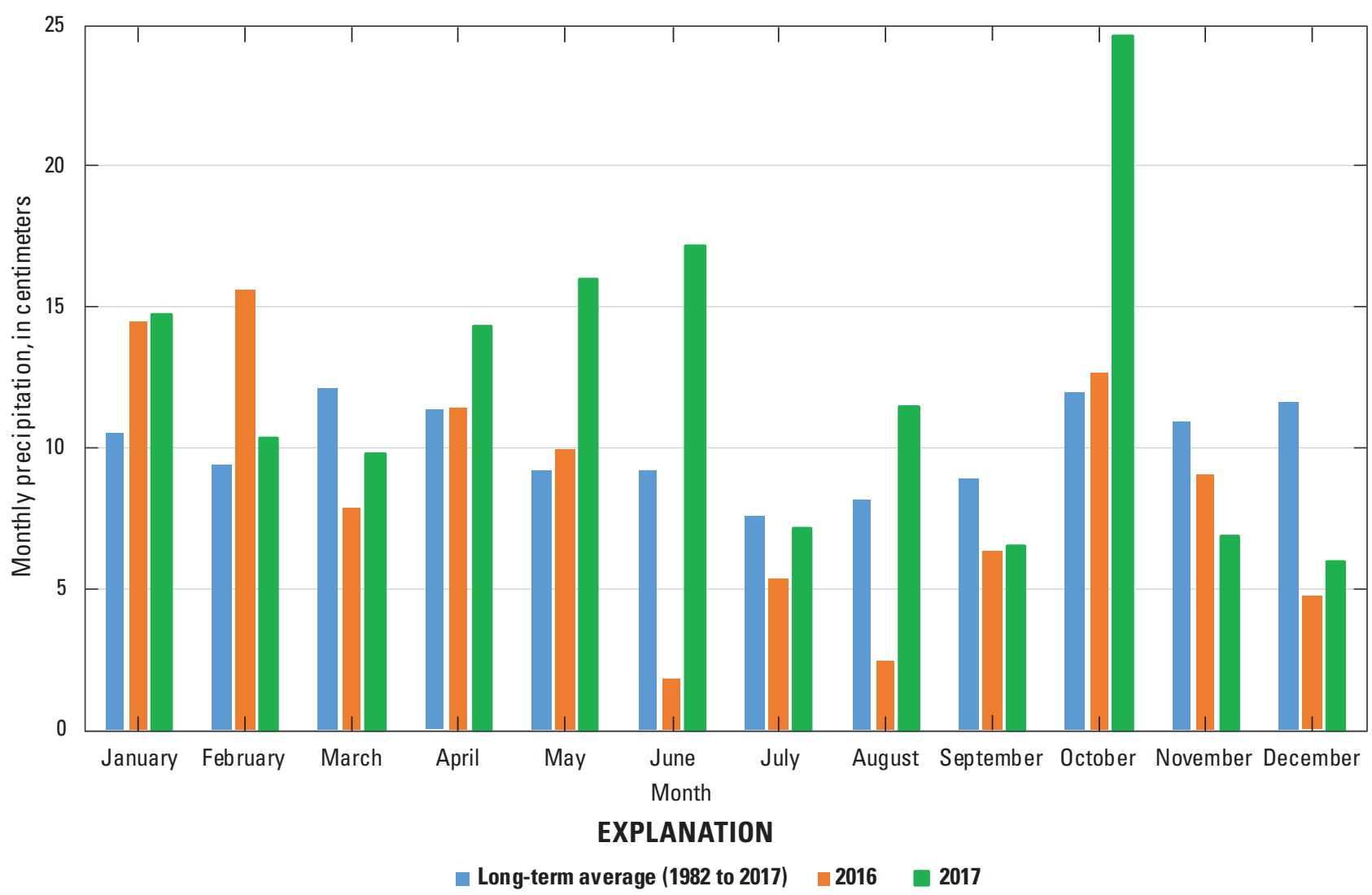

Figure 7. Monthly average precipitation in Truro, Massachusetts, for 2016, 2017, and the long-term (1982 to 2017, excluding 1987) average. Data from the Western Regional Climate Center (2018).

\section{Continuous Water-Quality Measurements at Herring River at Chequessett Neck Road}

Dissolved oxygen (DO) on the Herring River at the dike at Chequessett Neck Road varied seasonally such that the average concentration decreased through the spring and summer to a minimum value $(<2 \mathrm{mg} / \mathrm{L}$ of DO) in midsummer to late summer 2016 and increased to a maximum value $(>10 \mathrm{mg} / \mathrm{L}$ of DO) in the following winter (fig. 8). These seasonal changes in DO are presumably driven by algal photosynthesis, microbial respiration dynamics, and changes in water temperature. The average concentration of DO was lower in the summer of 2016 than in the summer of 2017 (fig. 8). DO and water temperature are inversely related. Higher water temperatures and associated lower DO concentrations in the summer of 2016 would be consistent with shallower water and lower freshwater runoff in the Herring River in 2016 than in 2017.

DO generally varied diurnally, being higher in the afternoon and evening than the morning; the greatest diurnal difference was in summer (fig. 9). In spring and fall, the diurnal variation was consistent with that observed in summer, but the difference was smaller. This diurnal variation was much less evident and sometimes absent in winter. Tidal variation has little influence on DO concentration.
Values of $\mathrm{pH}$ for the Herring River at the dike at Chequessett Neck Road varied between about 7 and 8 throughout the year (fig. 10). Equipment failure resulted in no $\mathrm{pH}$ records for the summer of 2016; however, the summer of 2017 generally (except for a 3-week period in August) had somewhat lower minimum $\mathrm{pH}$ values (frequently in the range of 6.5 to 7.0) than observed in other seasons. Diurnal variation in $\mathrm{pH}$ tracked the tides, reaching a maximum at slack high tide and a minimum at slack low tide (fig. 9).

Specific conductance $(\mathrm{SpC})$ on the Herring River at the dike at Chequessett Neck Road tracked the tidal cycles and typically varied between 20,000 and $48,000 \mu \mathrm{S} / \mathrm{cm}$ (fig. $11 A, B$ ). SpC appeared to decrease over time during the study period in both the ebb and flood tides. The average $\mathrm{SpC}$ in the summer (June through August) in 2016 was $37,073 \mu \mathrm{S} / \mathrm{cm}$. The average $\mathrm{SpC}$ in the summer in 2017 was $33,132 \mu \mathrm{S} / \mathrm{cm}$. These differences in $\mathrm{SpC}$ were consistent with the observed $9.5 \mathrm{~cm}$ of precipitation in the summer of 2016 (fig. 5) and $37.5 \mathrm{~cm}$ of precipitation in 2017. The fact that $\mathrm{SpC}$ on the ebb tide in summer 2017 was less than in the summer of 2016 indicates a greater input of freshwater from precipitation and possibly groundwater discharge to the Herring River.

The long-term trend in gage height recorded during the ebb tide shows a slight increase (towards a higher water level) over time during the study period (fig. 11C). This increase is consistent with the trend towards decreasing $\mathrm{SpC}$ (fig. 11A) 


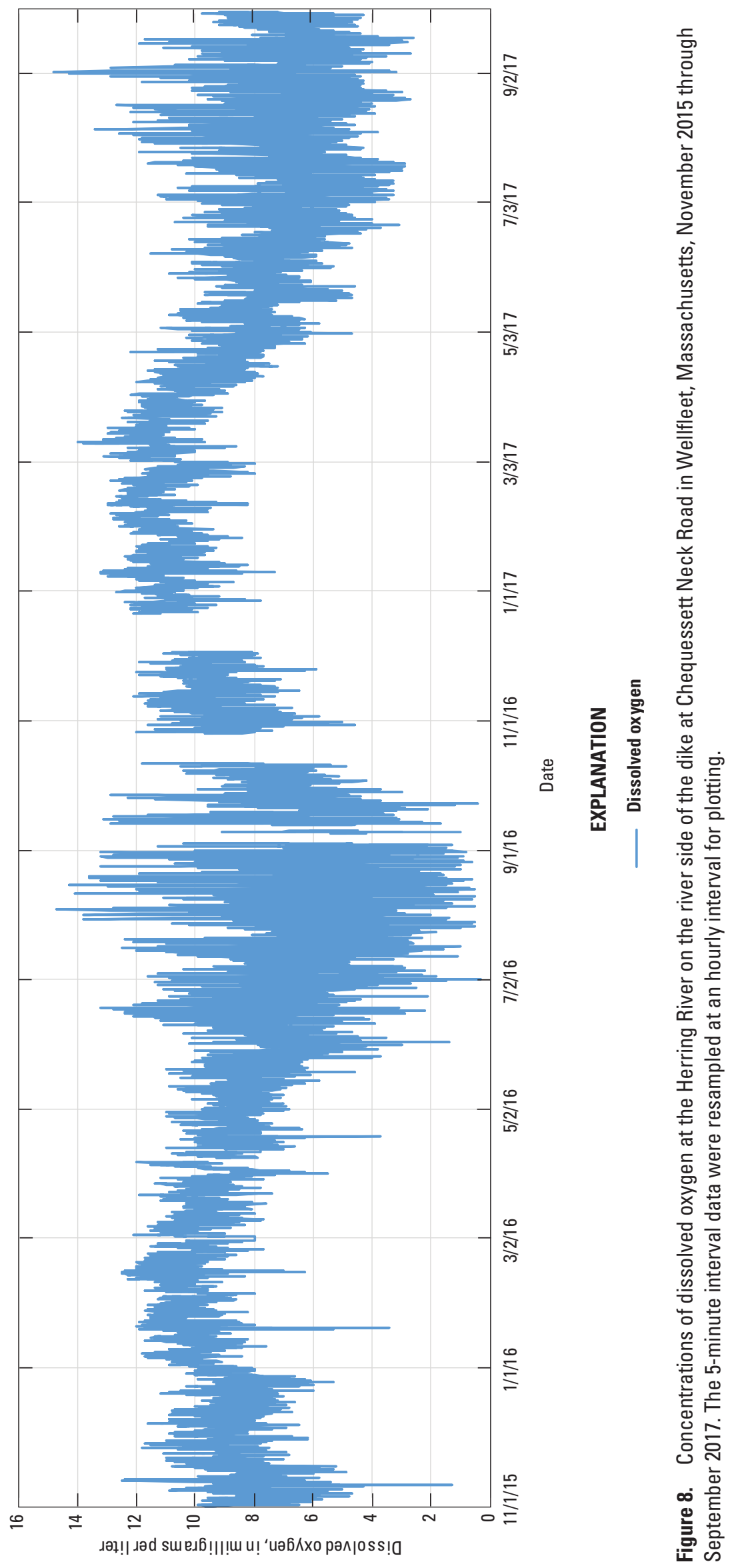




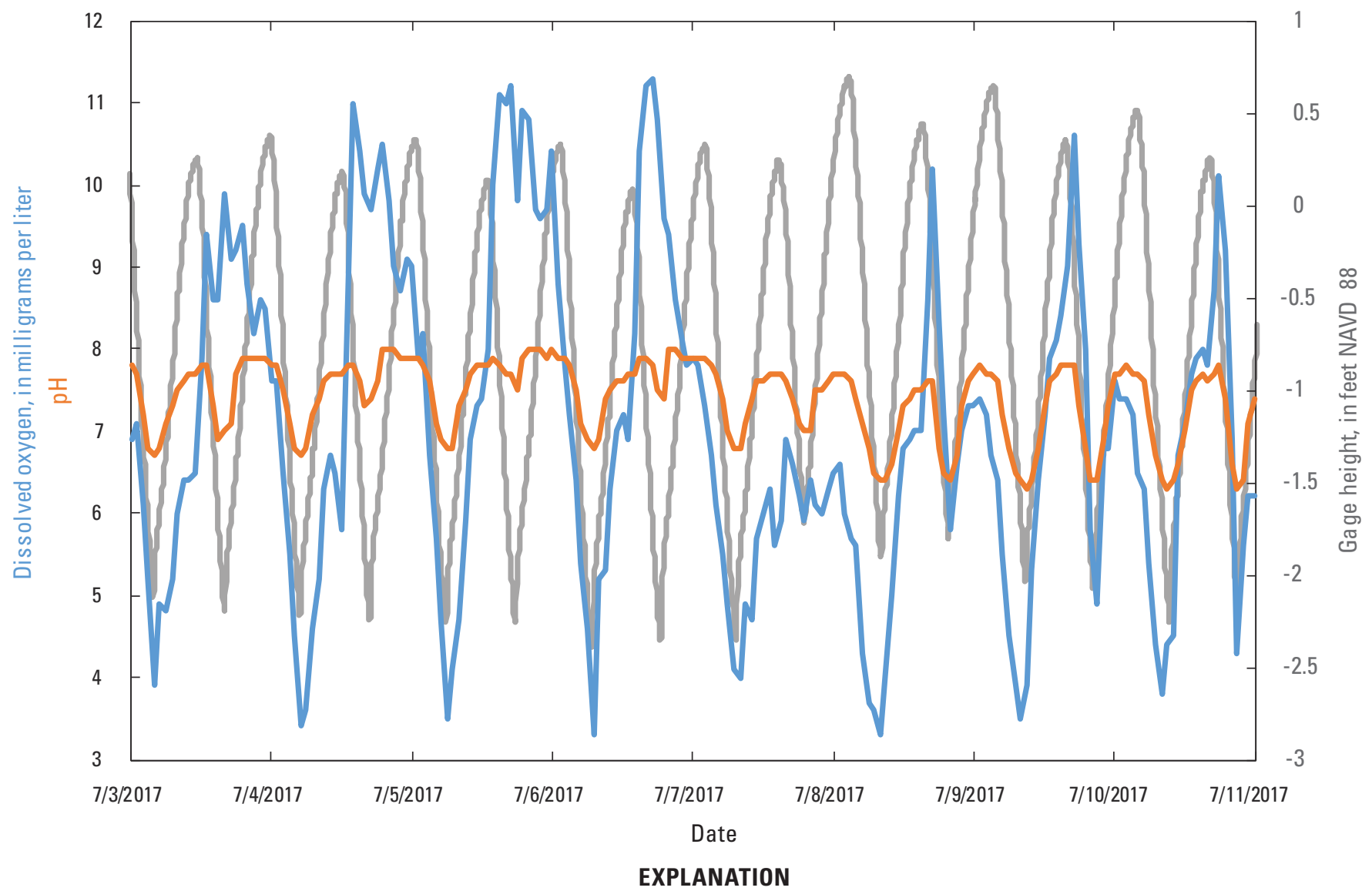

EXPLANATION

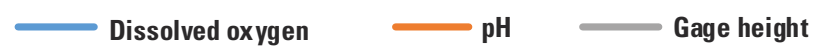

Figure 9. Dissolved oxygen, $\mathrm{pH}$, and gage height for the Herring River on the river side of the dike at Chequessett Neck Road in Wellfleet, Massachusetts, during mid-July 2017. The 5-minute interval data were resampled at an hourly interval for plotting. feet NAVD 88, feet relative to the North American Vertical Datum of 1988.

and with the trend towards increasing precipitation (fig. 5). The average gage height on the ebb tide in the summer (June through August) in 2016 was $-1.17 \mathrm{ft}$. The average gage height in the summer in 2017 was $-1.05 \mathrm{ft}$.

The long-term trend in surface-water velocity used to develop the index-velocity rating is also indicative of an unexpected change over time. During the month of January 2017, there appeared to have been a substantial decrease in the peak and average velocities on the ebb tide (fig. 11D). Prior to this apparent shift, the long-term average velocity on the ebb tide was $6.63 \mathrm{ft} / \mathrm{s}$, and after this date, the long-term average velocity was $6.18 \mathrm{ft} / \mathrm{s}$ (a 6.7 -percent decrease). Before this apparent shift, the peak velocities on the ebb tide generally were between 9 and $10 \mathrm{ft} / \mathrm{s}$, and after January 2017, they generally were between 8 and $9 \mathrm{ft} / \mathrm{s}$. There was no comparable shift in velocity on the flood tide in January 2017; and over the study period the flood tide velocities increased slightly (fig. 11E). We do not know why the measured ebb velocities decreased in January 2017 and remained at lower levels for the remainder of the study. The decrease in velocity could be the result of issues with the radar sensor unit such as a change in the internal programming in the radar unit, damage to the electronics in the radar unit, or a change in the angle of the sensor beam.

The velocity, $\mathrm{SpC}$, gage height, and precipitation data indicate a potential temporal bias in the discharge record. In one approach to evaluate whether the velocity record could have been compromised, we applied an adjustment to the ebb and flood velocity records based on an assumption that they were accurate before January 6, 2017. We computed the average velocities prior to and after this date and applied corrections of 1.080 times the post-January 5, 2017, ebb velocity and 0.973 times the post January 5, 2017, flood velocity to remove the trend in velocity. With this adjustment, there was no longer a downward trend in the ebb-minus-flood discharge record, nor did it become negative after April 2017. Calculation of the long-term average ebb-minus-flood discharge following the adjustment to the velocity record results in a 50-percent increase in estimated river flow from $2.11 \mathrm{ft} 3 / \mathrm{s}$ to $3.25 \mathrm{ft} 3 / \mathrm{s}$ $\left(0.060 \mathrm{~m}^{3} / \mathrm{s}\right.$ to $\left.0.092 \mathrm{ft}^{3} / \mathrm{s}\right)$. 


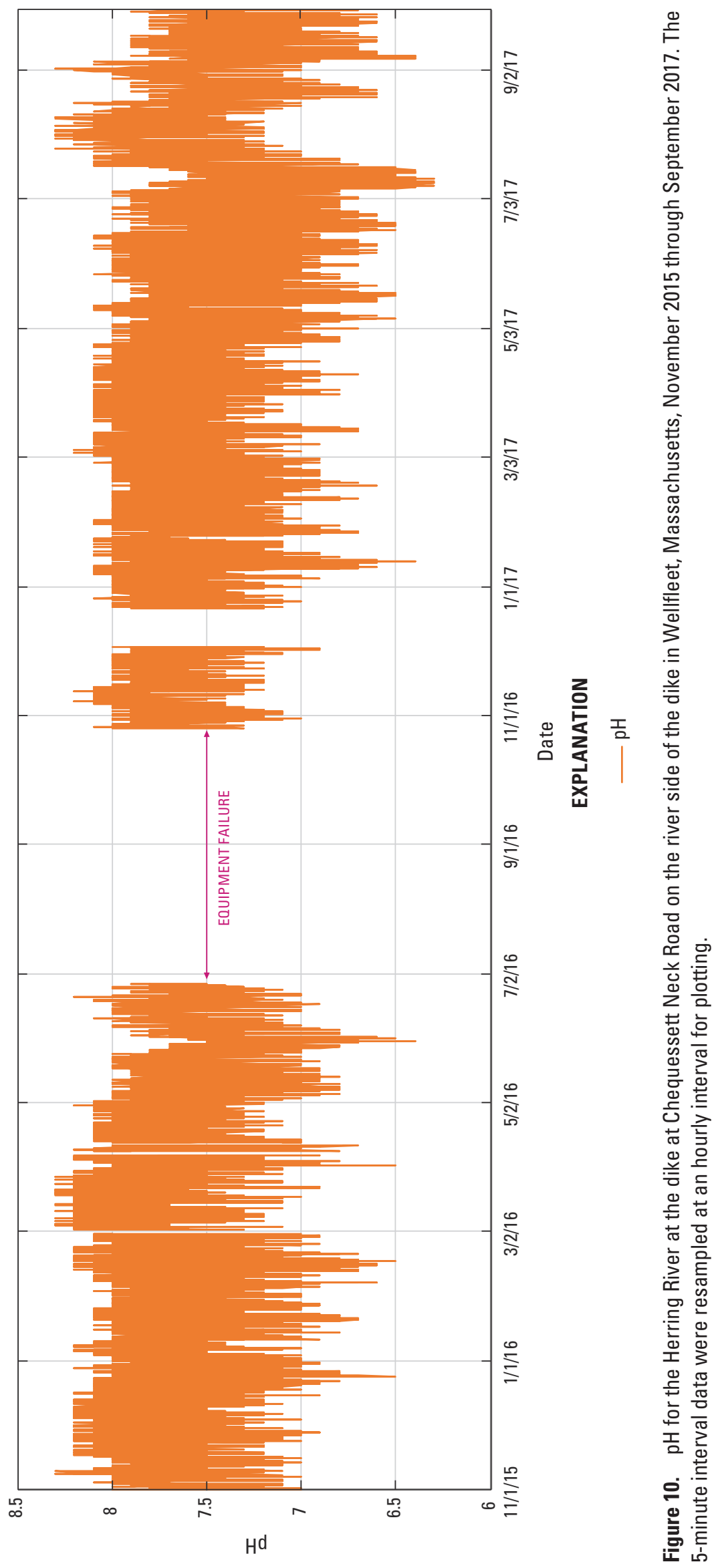




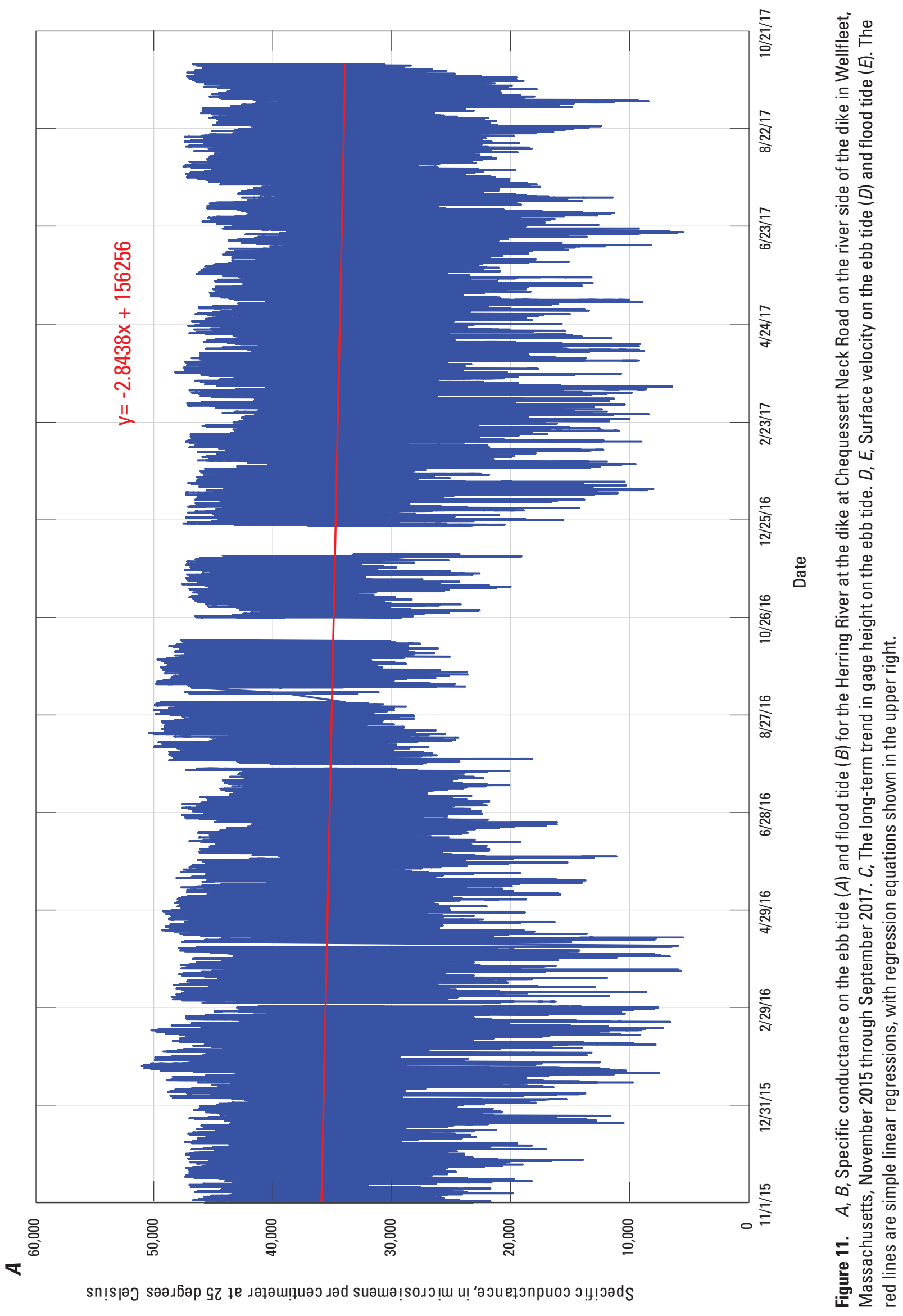




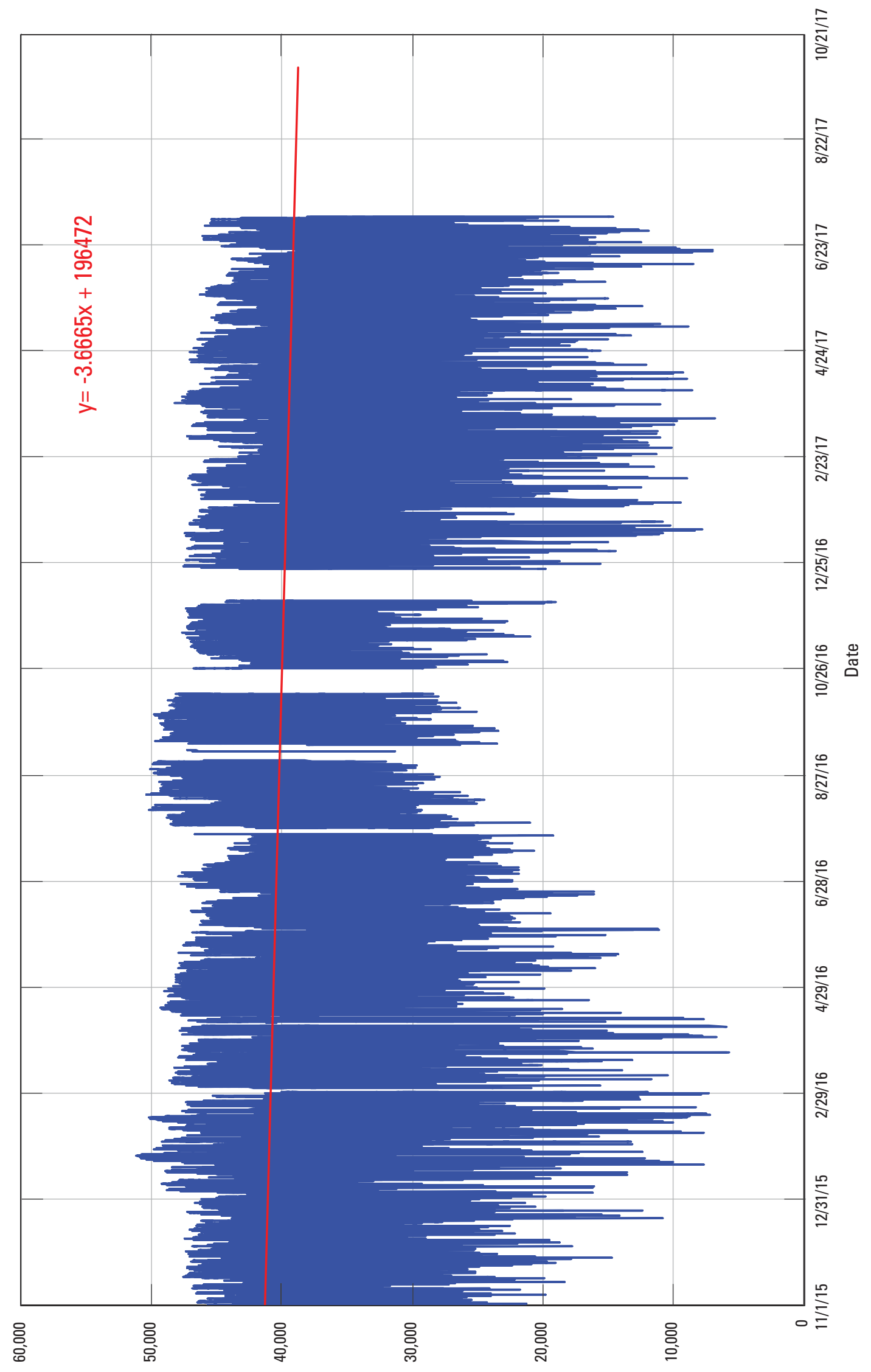

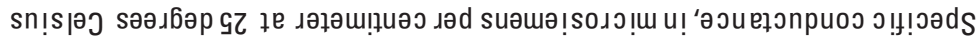




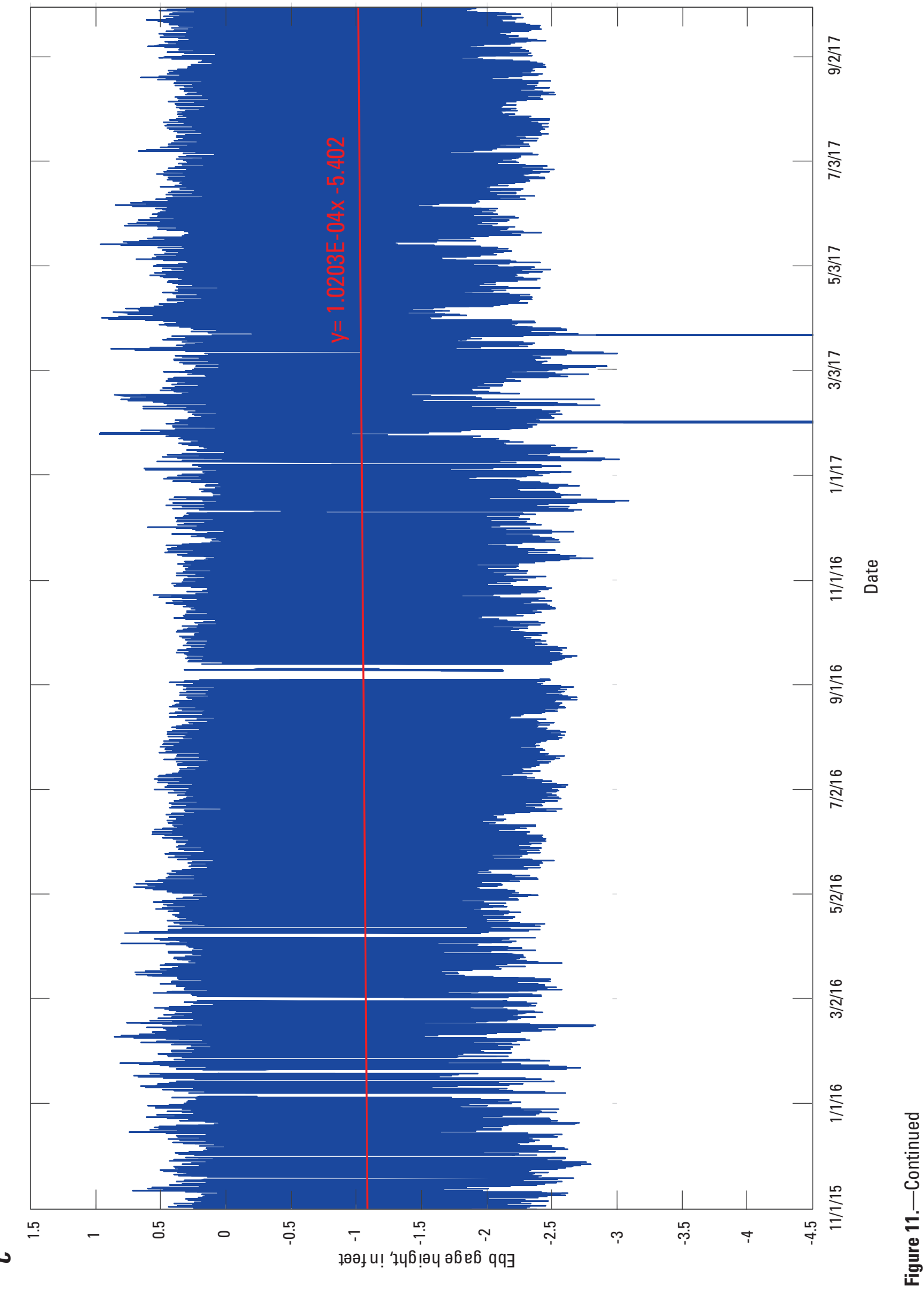




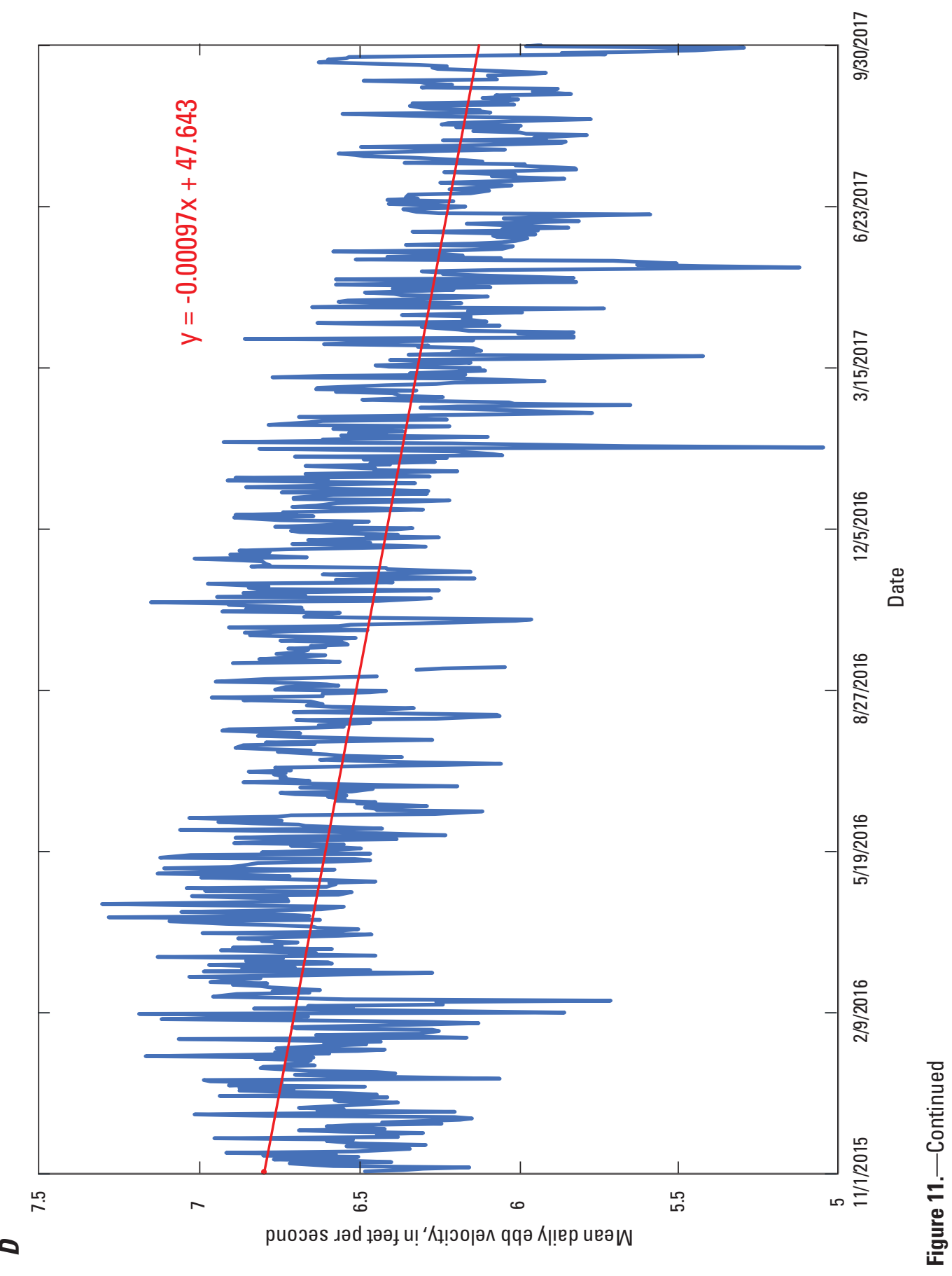




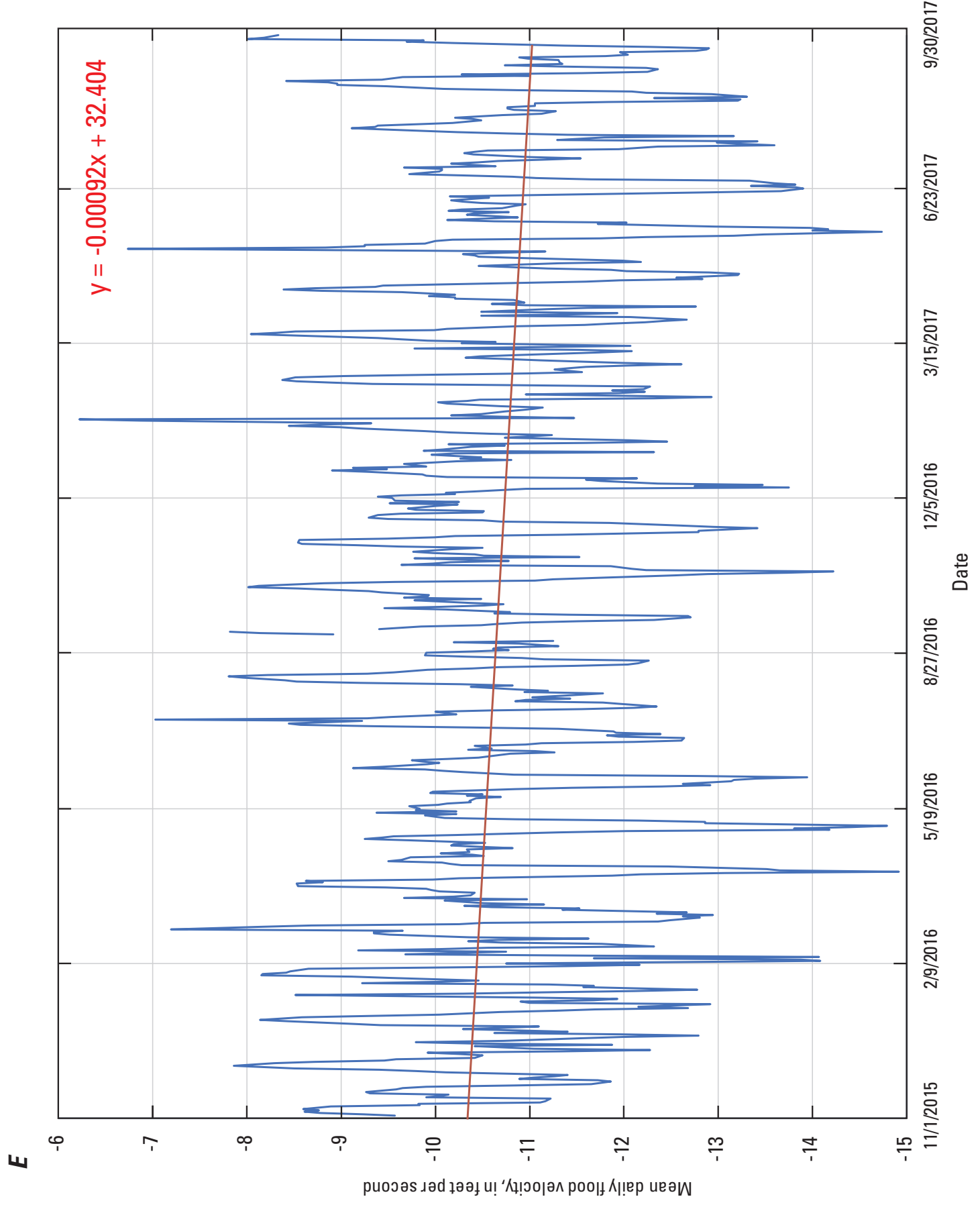


The greatest amplitude in $\mathrm{SpC}$ between flood and ebb tides occurred in winter when runoff was greatest, and the smallest amplitude occurred in summer when runoff and groundwater discharge were lower. The highest $\mathrm{SpC}$ on flood and ebb tides occurred in summer, in particular during the summer of 2016 when rainfall was substantially lower than in 2017. Specific conductance (SpC) tracks the tidal cycle, reaching a maximum at the end of the flood tide and a minimum at the end of the ebb tide (fig. 12). The minimum value for $\mathrm{SpC}$ for the record from October 1, 2015, to September 30, 2017, occurred on June 19, 2017.

Water temperature on the Herring River at the dike at Chequessett Neck Road followed the expected seasonal pattern with the maximum occurring in late summer and the minimum occurring in midwinter (fig. 6). Minimum water temperatures decreased to just below $0{ }^{\circ} \mathrm{C}$ in midwinter, and maximum temperatures occasionally exceeded $30^{\circ} \mathrm{C}$ in July and August. Water temperature generally varied diurnally, being higher in the afternoon and evening compared with the morning and with the greatest diurnal difference in summer (fig. 13).

\section{Variation in Nutrient Concentrations in the Herring River by Season, Antecedent Precipitation, and Tide Direction}

Flow-weighted concentrations of $\mathrm{NH}_{4}$, nitrate, and total nitrogen on the Herring River at the dike on the ebb tide generally varied between 0.01 and $0.1,0.003$ and 0.03 , and 0.3 and $0.7 \mathrm{mg} / \mathrm{L}$ as $\mathrm{N}$, respectively. Flow-weighted concentrations of orthophosphate, total dissolved phosphorus, and total phosphorus generally varied between 0.002 and $0.02,0.003$ and 0.06 , and 0.03 and $0.1 \mathrm{mg} / \mathrm{L}$ as phosphorus, respectively, on the ebb tide. Flow-weighted concentrations of silicate and dissolved organic carbon on the ebb tide generally varied between 0.08 and $3.0 \mathrm{mg} / \mathrm{L}$ of silica (silicon dioxide) and 1.7 and $5.6 \mathrm{mg} / \mathrm{L}$ of carbon, respectively.

Ammonium concentrations were substantially higher than nitrate concentrations in both flood and ebb water in the Herring River at Chequessett Neck Road (figs. 14 and 15). Ammonium concentrations did not exhibit systematic seasonal variation. There was a positive, statistically significant correlation between ebb (but not flood) $\mathrm{NH}_{4}$ concentration and 7-day

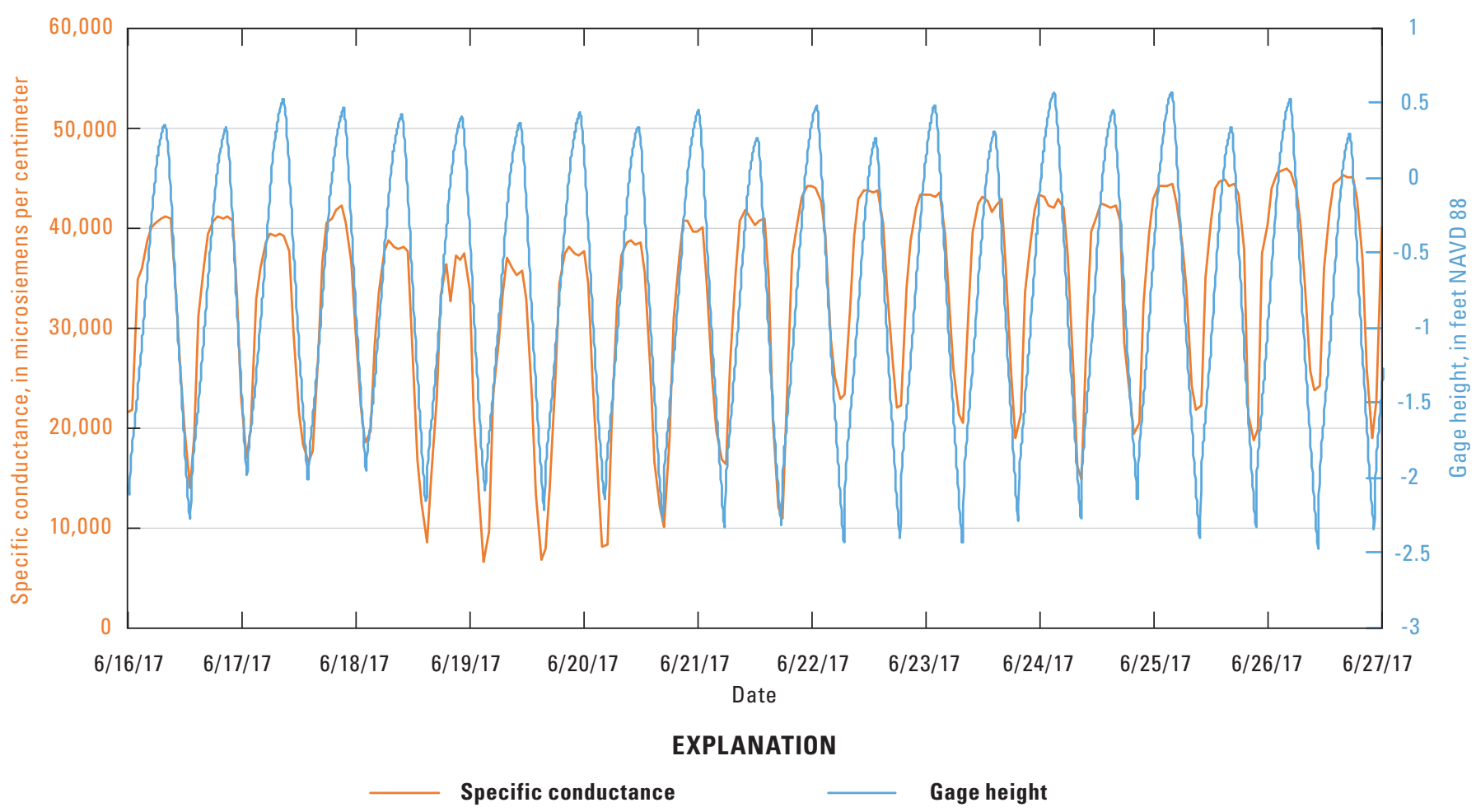

Figure 12. Specific conductance and gage height for the Herring River on the river side of the dike at Chequessett Neck Road in Wellfleet, Massachusetts, for the period from June 16, 2017, to June 27, 2017. The 5-minute interval data were resampled at an hourly interval for plotting. feet NAVD 88, feet relative to the North American Vertical Datum of 1988. 


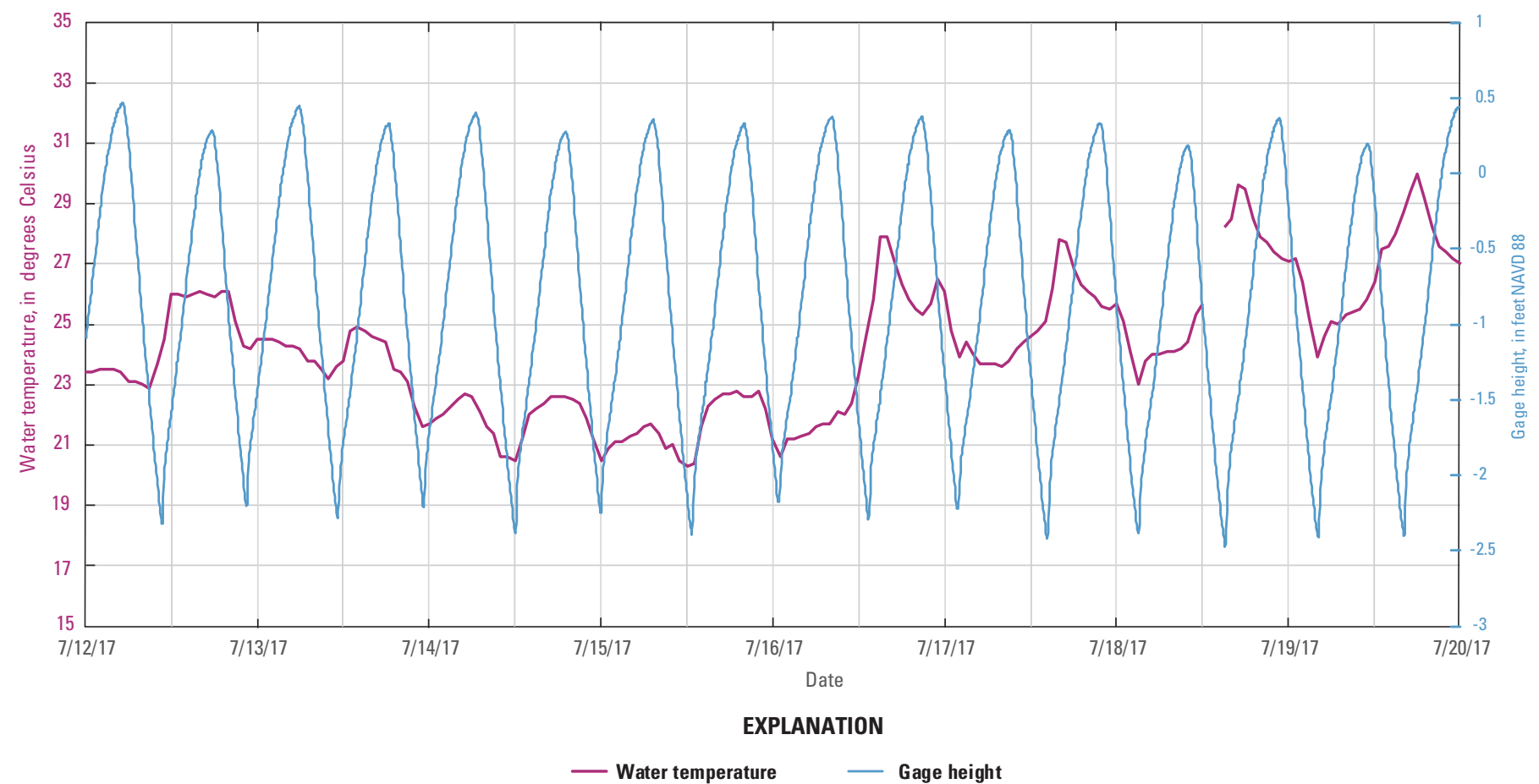

Figure 13. Temperature and gage height for the Herring River at the dike on the river side of Chequessett Neck Road in Wellfleet, Massachusetts (July 12 to July 20, 2017). The 5-minute interval data were resampled at an hourly interval for plotting. feet NAVD 88, feet relative to the North American Vertical Datum of 1988.

cumulative antecedent precipitation (table 4). Ammonium concentrations were usually higher in ebb tides than in preceding flood tides, and where the reverse was true, the differences were small and usually occurred in late summer.

Nitrate concentrations exhibited systematic seasonal variation, increasing in the fall, reaching a maximum in winter, decreasing in spring, and reaching minimum values in summer (fig. 15). There were positive, statistically significant correlations between flood nitrate concentration and 7-day cumulative antecedent precipitation and between ebb nitrate concentration and 7-day cumulative antecedent precipitation (table 4). Nitrate concentrations were usually substantially higher in ebb tides than in preceding flood tides, and the differences were largest in winter.

Total nitrogen (unfiltered; TN) concentrations in the Herring River at Chequessett Neck Road generally varied between 0.25 and $0.60 \mathrm{mg} / \mathrm{L}$ as $\mathrm{N}$ and did not exhibit systematic seasonal variation (fig. 16). There was a positive, statistically significant correlation between ebb (but not flood) TN concentration and 7-day cumulative antecedent precipitation (table 4). TN concentrations on the ebb tides were usually higher than on preceding flood tides, although in many instances the differences were small. Most of the nitrogen transported on both flood and ebb tides was in the form of organic nitrogen, as is evident from comparing TN and inorganic nitrogen species (figs. 14, 15, and 16). Organic nitrogen concentration $\mathrm{N}_{\text {org }}$ is defined as

$$
\mathrm{N}_{\text {org }}=\mathrm{TN}-\mathrm{NH}_{4}-\left(\mathrm{NO}_{3}+\mathrm{NO}_{2}\right) .
$$

A limited number of analyses (16 flood and $16 \mathrm{ebb}$ composite samples from July 31,2017 , to September 25,2017 ) for filtered TN revealed that the average ratio of filtered to unfiltered nitrogen was 0.64 (typically ranging from 0.57 to 0.75 ). The ratios were similar between flood and ebb tides. This indicates that, for this time period, most of the nitrogen was transported in dissolved organic form as opposed to dissolved inorganic nitrogen or particulate organic nitrogen.

Orthophosphate concentrations in the Herring River at Chequessett Neck Road exhibited systematic strong seasonal variation, whereby concentrations were low in winter and spring and increased markedly in summer, peaked in late summer, and then declined over the fall (fig. 17). Orthophosphate concentrations in flood and ebb water were not correlated with 7-day cumulative antecedent precipitation (table 4). Orthophosphate concentrations were similar between flood and ebb tides.

Total dissolved phosphorus (TDP) concentrations in the Herring River at Chequessett Neck Road exhibited the same systematic strong seasonal variation as observed for orthophosphate (fig. 18). TDP concentrations in flood and ebb water were not correlated with 7-day cumulative antecedent precipitation (table 4). TDP concentrations were similar between flood and ebb tides. 

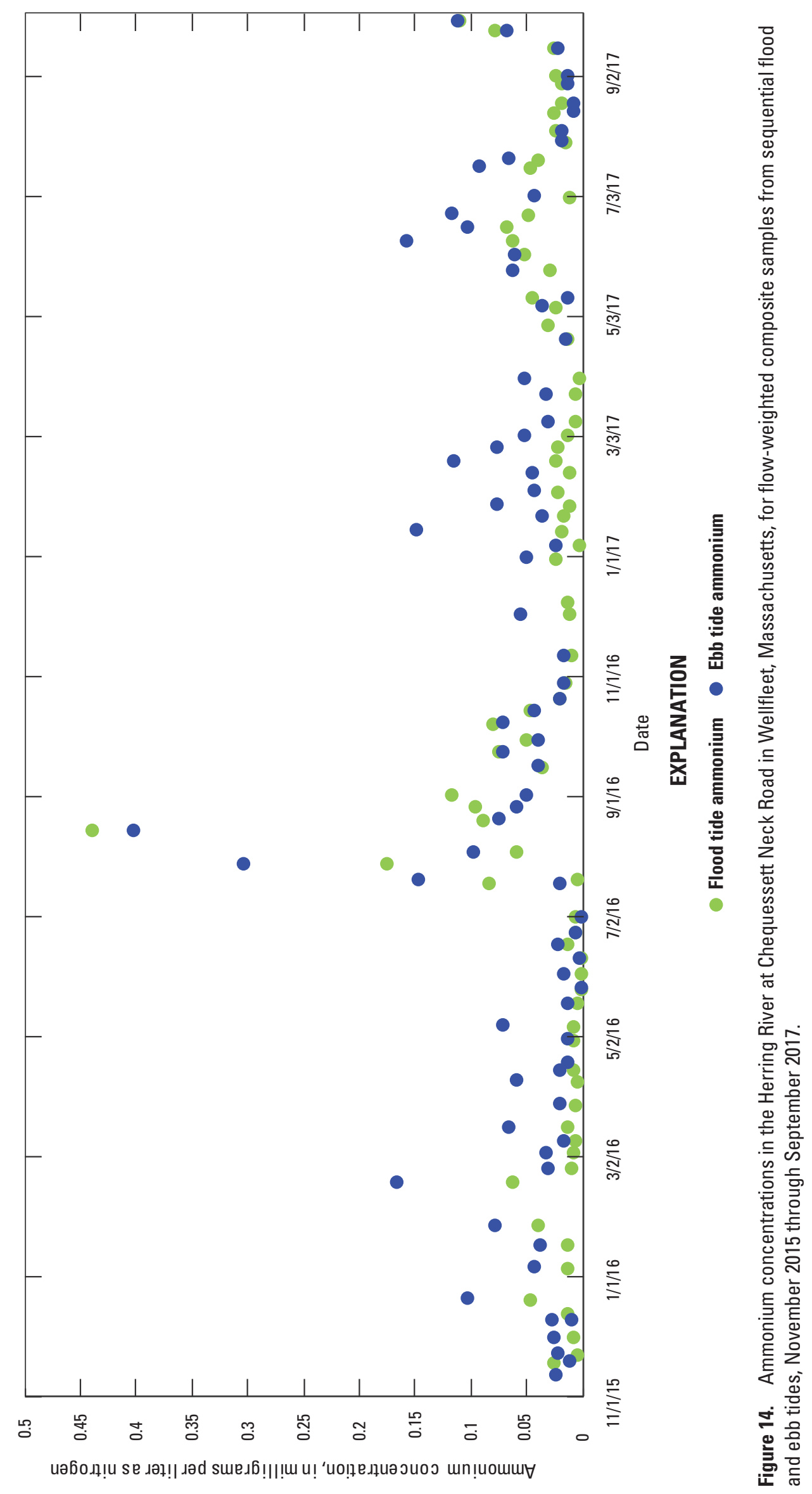


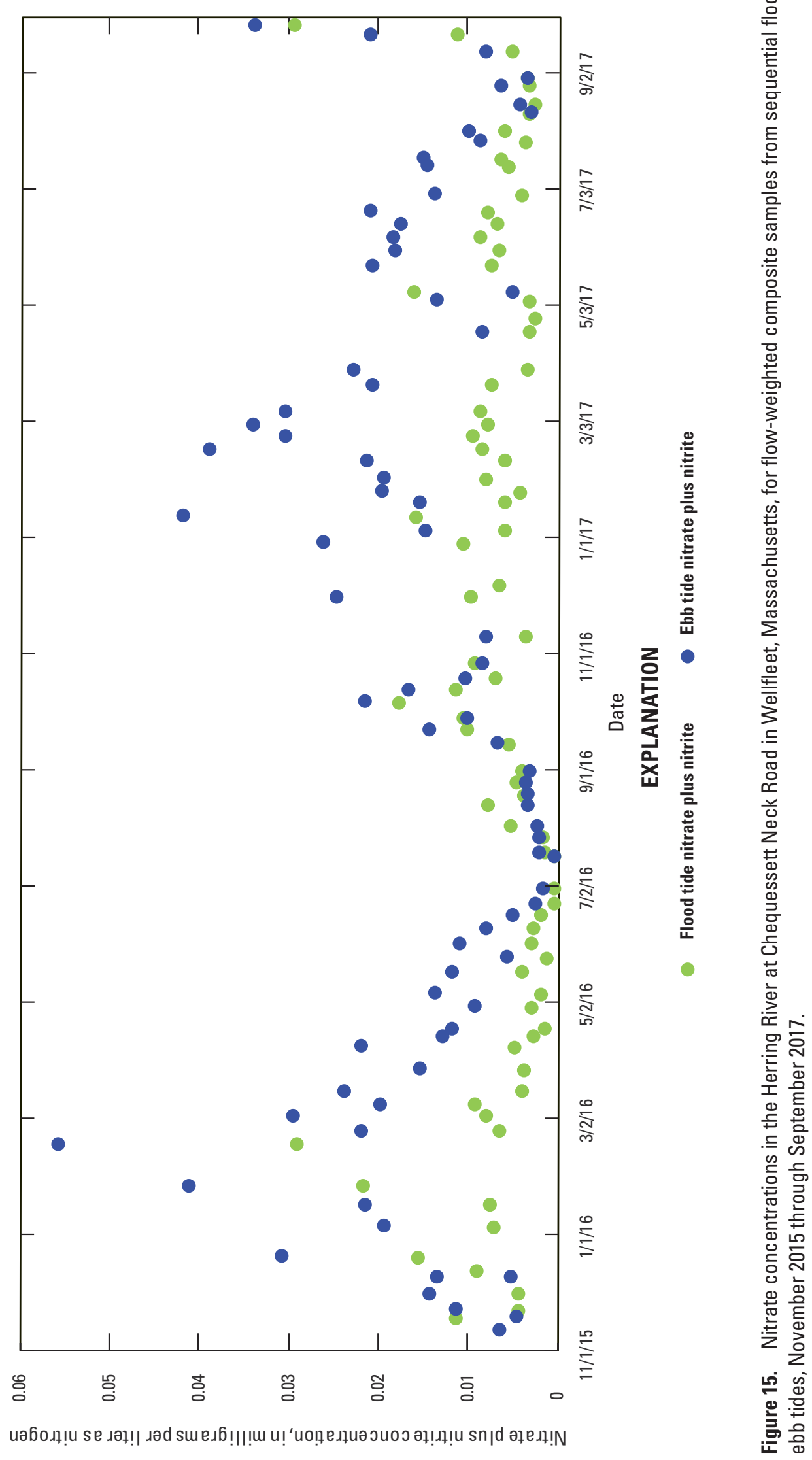


Table 4. Kendall rank correlations between nutrient concentrations and cumulative precipitation in the previous 7 days in the Herring River at Chequessett Neck Road, Wellfleet, Massachusetts.

[tau; Kendall's rank correlation coefficient; TP, total phosphorus; TDP total dissolved phosphorus; TN, total nitrogen; N, nitrogen; DOC, dissolved organic carbon; NS, not significant]

\begin{tabular}{llcc}
\hline \multicolumn{1}{c}{ Variable } & $\begin{array}{c}\text { Flow direc- } \\
\text { tion }\end{array}$ & tau & p-value \\
\hline Ammonium & Ebb & 0.229 & 0.0033 \\
Nitrate + nitrite & Ebb & 0.338 & $<0.0001$ \\
TP & Ebb & -0.031 & NS \\
TDP & Ebb & -0.081 & NS \\
Orthophosphate & Ebb & -0.024 & NS \\
TN & Ebb & 0.171 & 0.026 \\
Organic N & Ebb & 0.127 & NS \\
Organic N fraction & Ebb & -0.127 & NS \\
Silica & Ebb & 0.253 & 0.0012 \\
DOC & Ebb & 0.053 & NS \\
Ammonium & Flood & 0.061 & NS \\
Nitrate + nitrite & Flood & 0.216 & 0.0046 \\
TP & Flood & -0.029 & NS \\
TDP & Flood & -0.130 & NS \\
Orthophosphate & Flood & -0.070 & NS \\
TN & Flood & 0.076 & NS \\
Organic N & Flood & 0.086 & NS \\
Organic N fraction & Flood & -0.013 & NS \\
Silica & Flood & 0.212 & 0.0055 \\
DOC & Flood & -0.021 & NS \\
\hline
\end{tabular}

Total phosphorus (unfiltered; TP) concentrations in the Herring River at Chequessett Neck Road generally varied between 0.02 and $0.10 \mathrm{mg} / \mathrm{L}$ as phosphorus $(\mathrm{P})$ and exhibited the same systematic, strong seasonal variation as observed for orthophosphate (fig. 19). TP concentrations in flood and ebb water were not correlated with 7-day cumulative antecedent precipitation (table 4). TP concentrations were similar between flood and ebb tides. The difference between TP and TDP indicated that, on average, the dissolved fraction constituted about 39 percent of the TP on flood tides and 36 percent on ebb tides.

Silica concentrations in the Herring River at Chequessett Neck Road did not exhibit systematic seasonal variation (fig. 20). There was a positive, statistically significant correlation between flood and ebb silica concentrations and 7-day cumulative antecedent precipitation and precipitation (table 4). Silica concentrations on the ebb tides were usually higher than on preceding flood tides, although during the winter/spring period, late December 2016 to early May 2017, the reverse was true.
DOC concentrations in the Herring River at Chequessett Neck Road did not exhibit systematic seasonal variation (fig. 21). However, in the summer of 2017, DOC concentrations were higher than in any other season, and this may be related to substantially higher rainfall and (or) higher temperatures overall in summer 2017 than in other seasons. However, DOC concentrations in flood and ebb water were not correlated with 7-day cumulative antecedent precipitation (table 4). DOC concentrations were typically similar on flood and ebb tides, except during summer, when DOC concentrations were frequently higher on flood tides.

\section{Nutrient Fluxes Across the Ocean-Estuary Boundary}

The following section describes the annual and seasonal nutrient fluxes across the ocean-estuary boundary at the dike at Chequessett Neck Road, which were estimated for the period from November 2015 to September 2017. The seasons were defined as spring (March through May), summer (June through August), fall (September through November), and winter (December through February). Fluxes from the estuary to the ocean on the ebb tides are referred to as exports (table 5), and fluxes from the ocean to the estuary on the flood tides are referred to as inputs The standard errors of the estimates (table 5) are derived from the uncertainty in the LOADEST regression model only and do not include the uncertainty associated with the discharge record.

Exports of TN and inorganic nitrogen species exceeded inputs annually in all seasons, except for ammonium $\left(\mathrm{NH}_{4}\right)$ in summer. Annual TN export averaged 85 kilograms per day $(\mathrm{kg} / \mathrm{d})$, and TN input averaged $66 \mathrm{~kg} / \mathrm{d}$. The difference, interpreted as the contribution of the Herring River to the total export, was $20 \mathrm{~kg} / \mathrm{d}$ (table 5). TN export varied only slightly over the four seasons, but inputs were about 71 to $74 \mathrm{~kg} / \mathrm{d}$ in summer and fall and only 57 to $59 \mathrm{~kg} / \mathrm{d}$ in winter and spring (table 5). Annual $\mathrm{NH}_{4}$ exports averaged $9.5 \mathrm{~kg} / \mathrm{d}$, and $\mathrm{NH}_{4}$ inputs averaged $6.0 \mathrm{~kg} / \mathrm{d}$, indicating a river contribution of $3.5 \mathrm{~kg} / \mathrm{d}$ (table 5). Ammonium exports were highest in spring and fall, and inputs were highest in summer and fall. Annual $\mathrm{NO}_{3}$ exports averaged $3.0 \mathrm{~kg} / \mathrm{d}$, and $\mathrm{NO}_{3}$ inputs averaged $1.1 \mathrm{~kg} / \mathrm{d}$, indicating a river contribution of $1.89 \mathrm{~kg} / \mathrm{d}$. Nitrate exports were highest in winter and spring, and inputs were highest in fall and winter. Lower nitrate exports in summer and fall are likely due to reduced river discharge and uptake by phytoplankton in the estuary. Average annual TN export was nearly 7 times larger than the sum of inorganic nitrogen $\left(\mathrm{NH}_{4}\right.$ and $\left.\mathrm{NO}_{3}\right)$ export, indicating that the primary form of nitrogen exported was organic nitrogen. Similarly, TN inputs were about 9 times larger than inorganic nitrogen inputs.

Exports of TP, TDP, and orthophosphate exceeded inputs annually and in all seasons, except orthophosphate in summer and fall (table 5). The fact that the concentrations of these constituents were similar suggests that the differences between export and input are caused by differences 


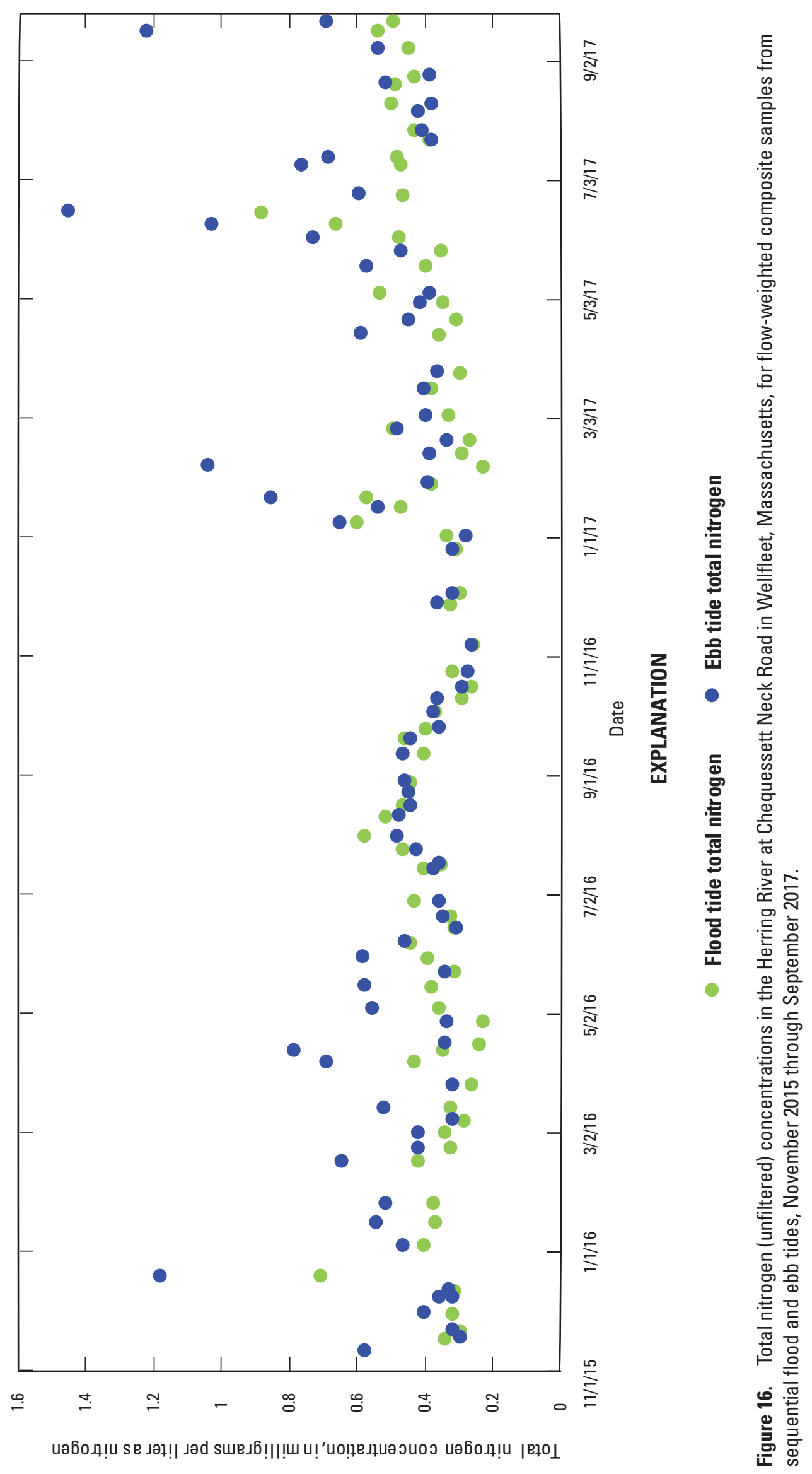




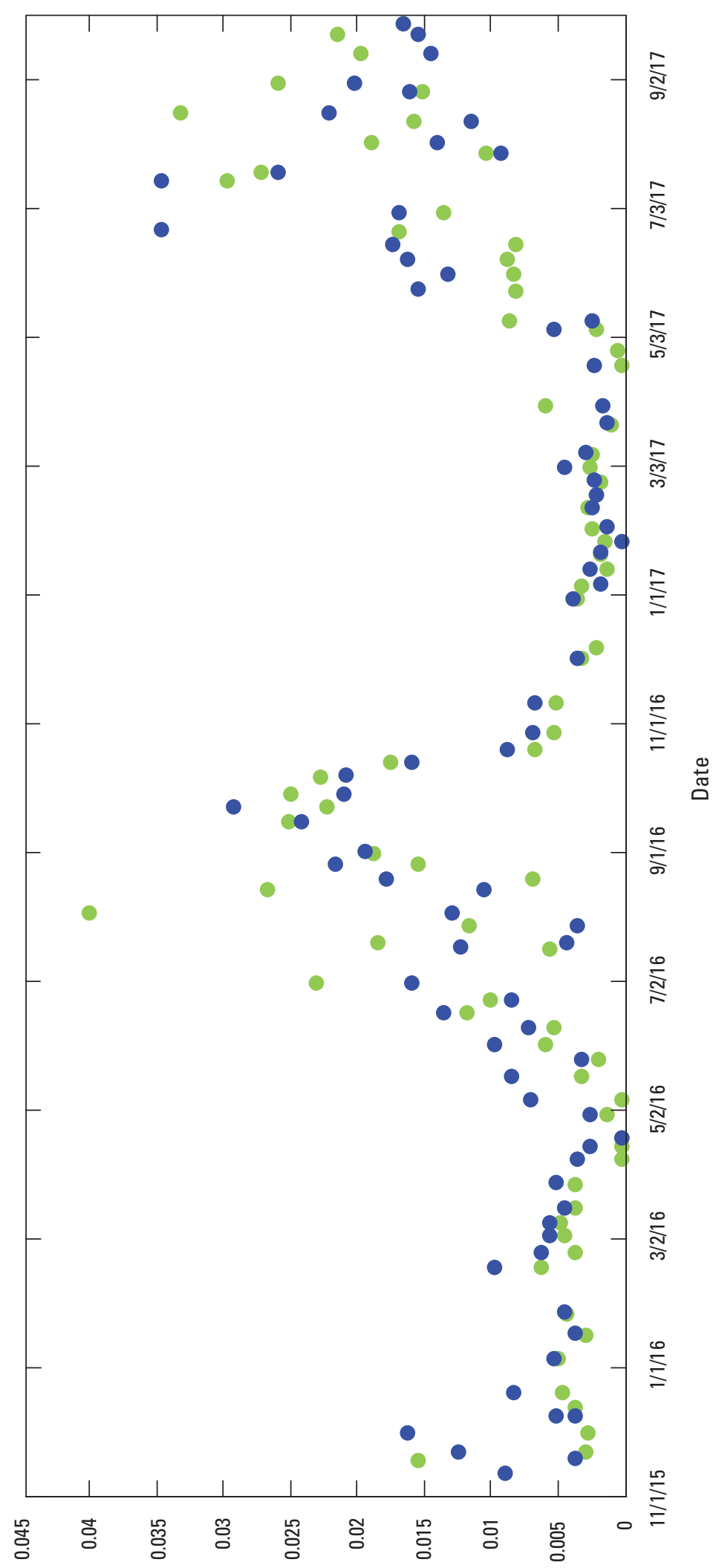

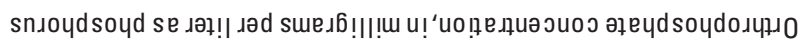

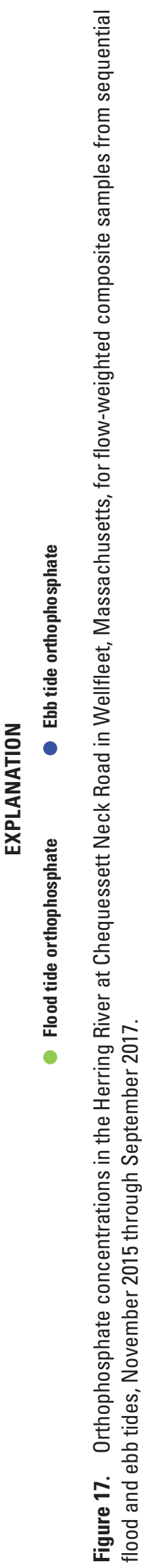




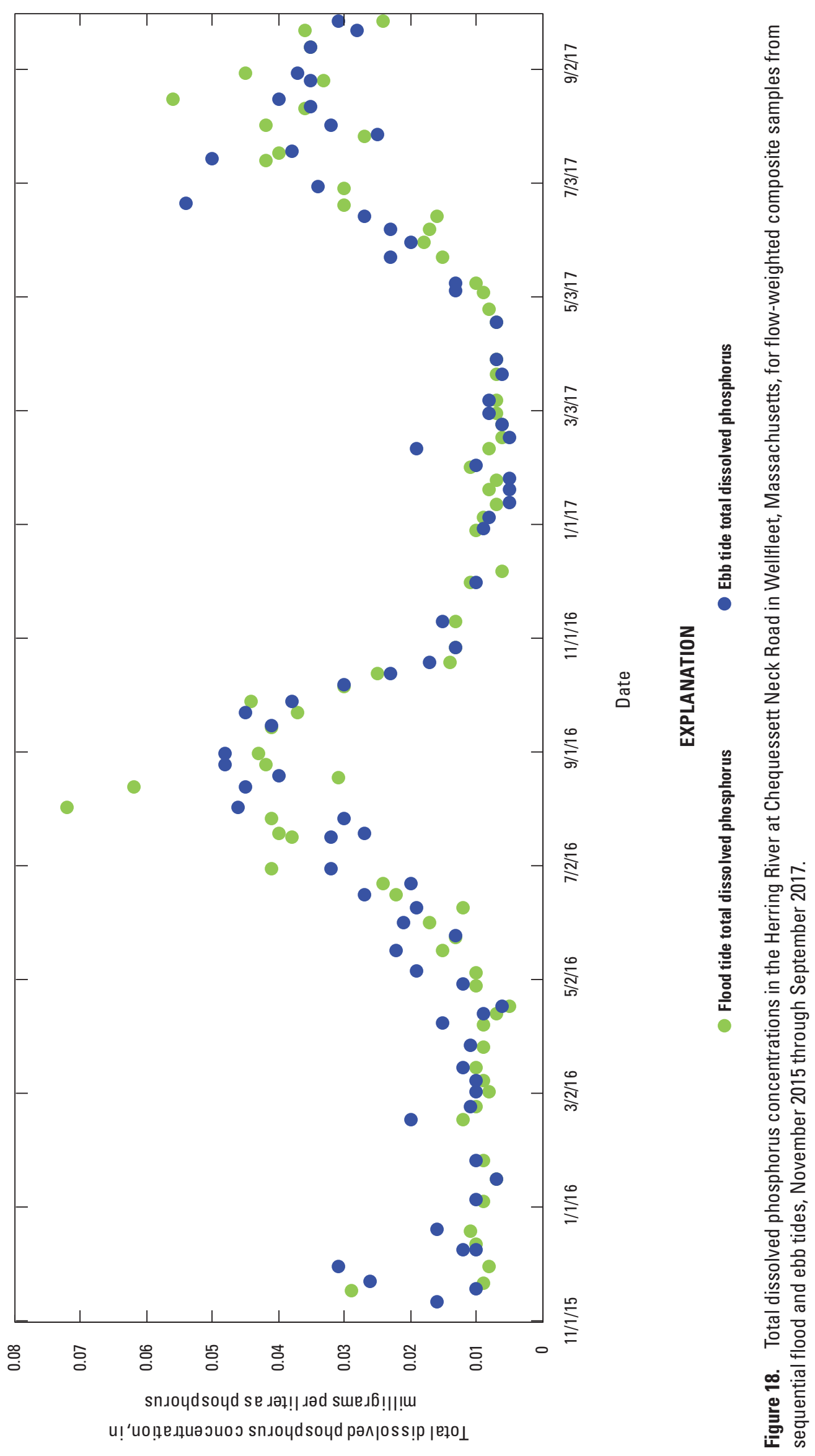




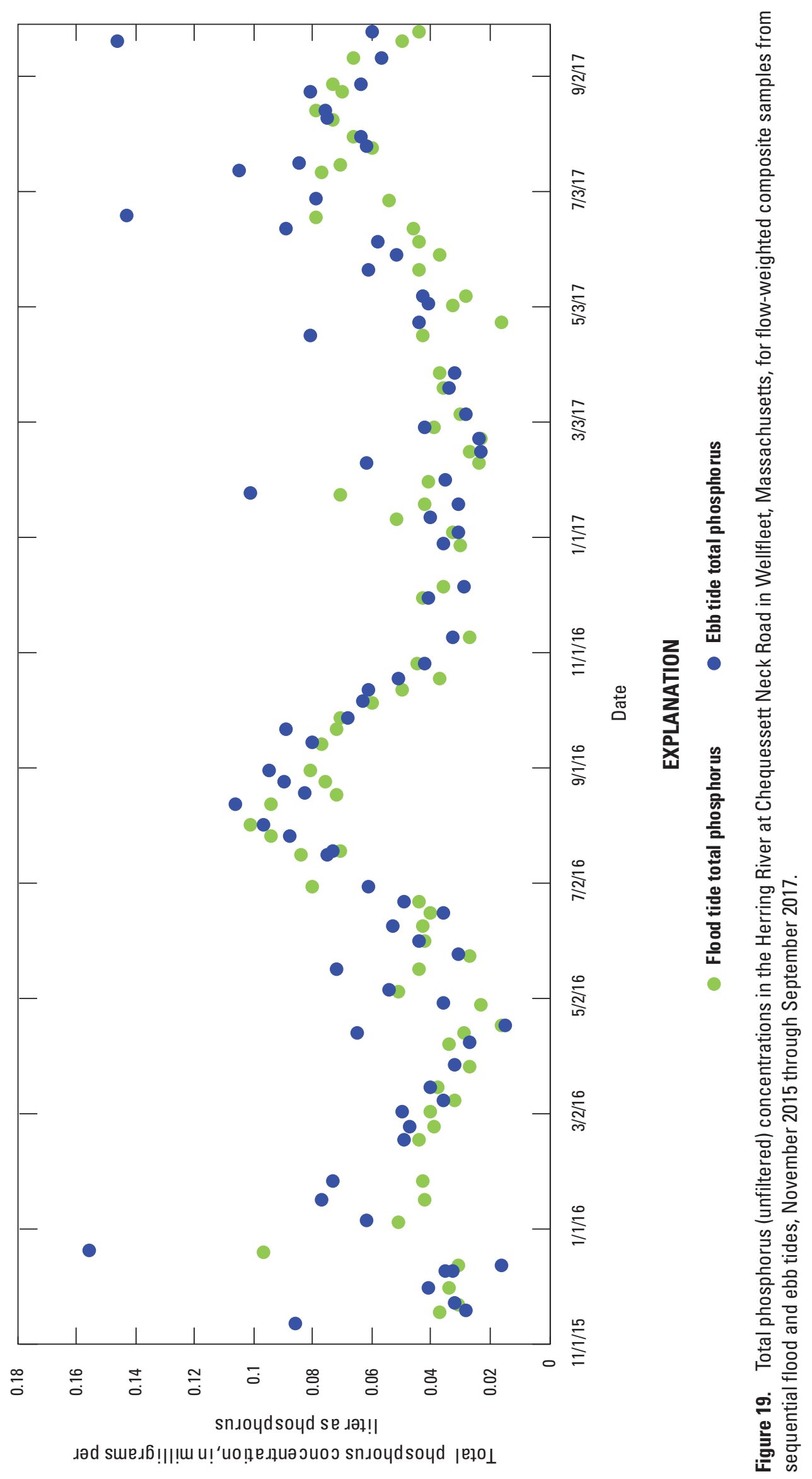




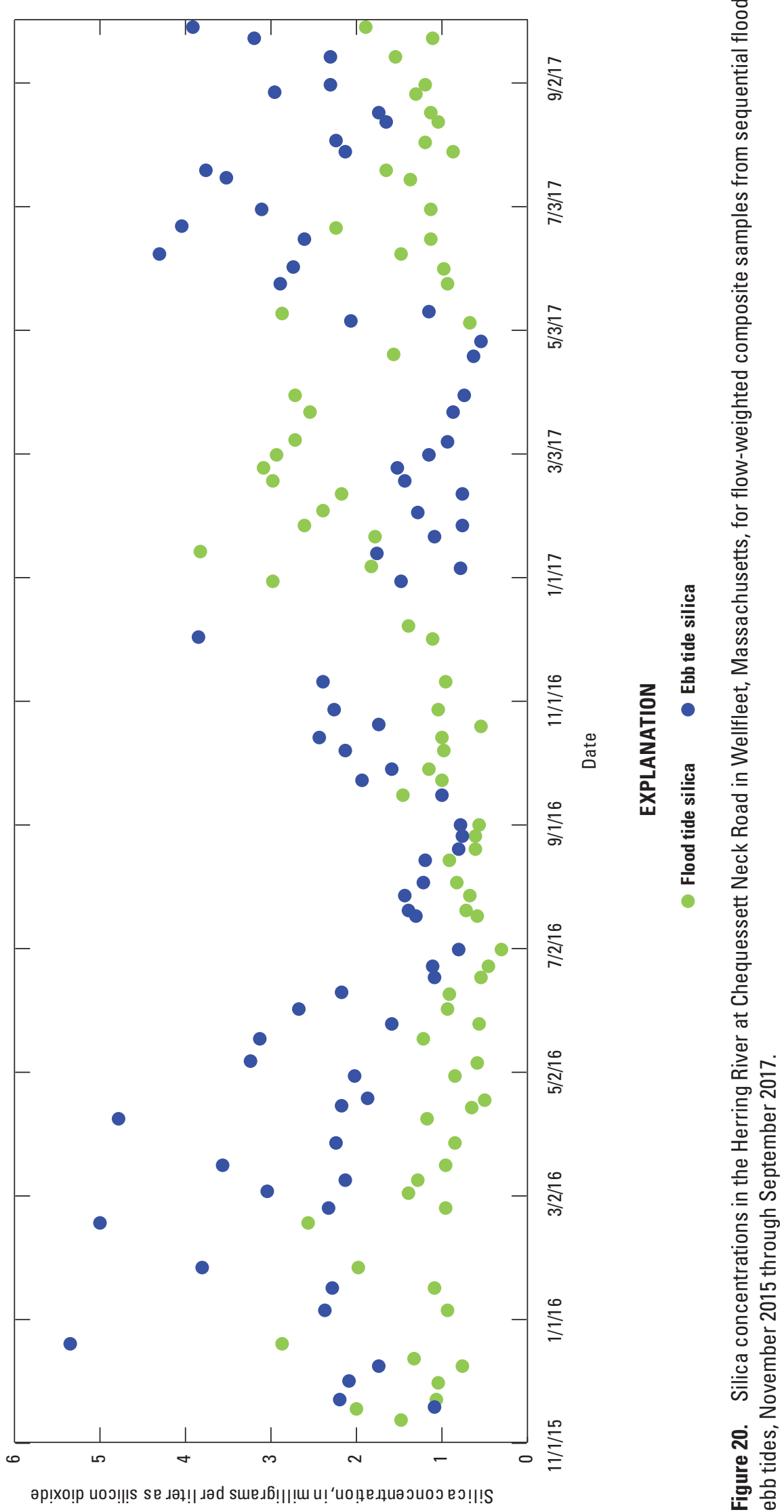




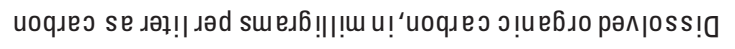

$\pm \simeq \quad \infty \quad \sim \quad \sim \quad 0$
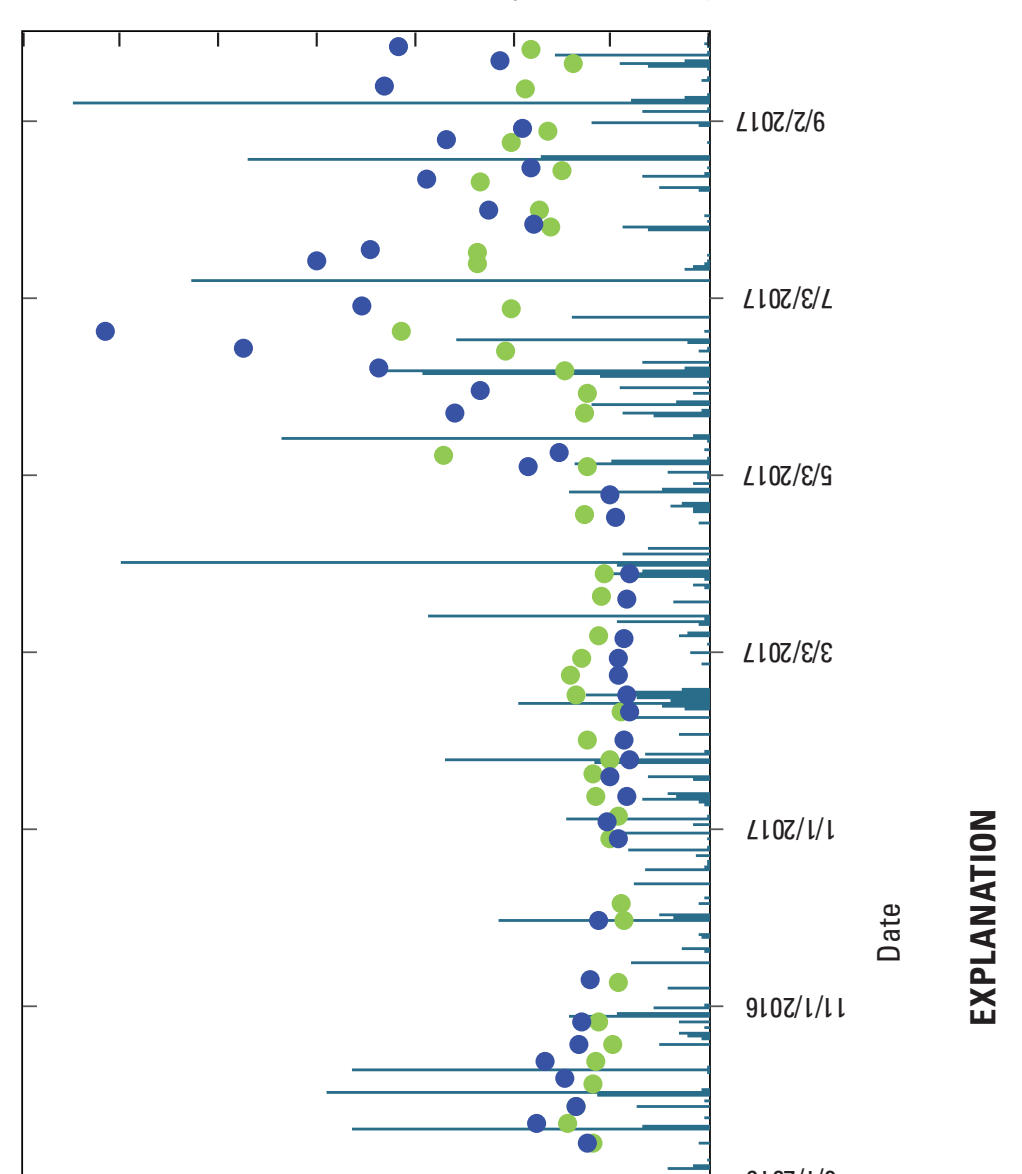

$9102 / 1 / 6$

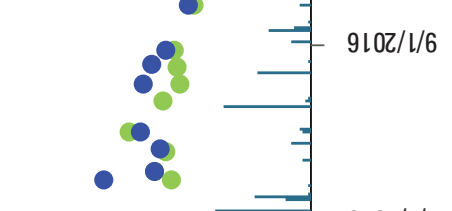

$910 z / 2 / L$

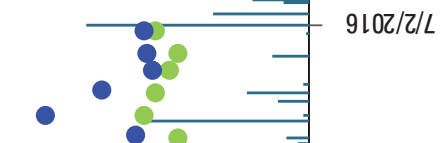

$9102 / 2 / 9$

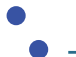
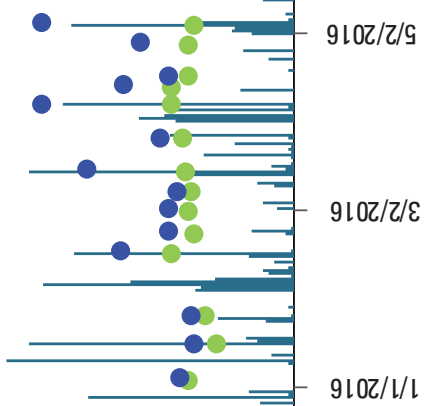

$910 z / l / l$
跣

政

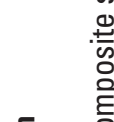

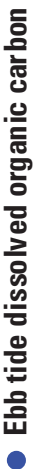

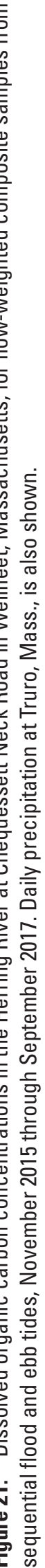


Table 5. Seasonal and annual nutrient loads computed in LOADEST for flood and ebb tides, and estimation of the fraction of the ebb tide that is derived from the Herring River in Wellfleet, Massachusetts, calculated as ebb minus flood.

[Loads and standard error values are in kilograms per day. The period of record is from November 2015 through September 2017. The seasons are defined as spring (March through May), summer (June through August), fall (September through November), and winter (December through February). The annual period is a calendar year (January through December). Constituents: TN, total nitrogen; NH4, ammonium; NO3, nitrate; TP, total phosphorus; TDP, total dissolved phosphorus; Ortho P, orthophosphate; Si, silica; DOC, dissolved organic carbon. Std err, standard error]

\begin{tabular}{|c|c|c|c|c|c|c|c|c|c|c|}
\hline \multirow{2}{*}{ Constituent } & \multicolumn{2}{|c|}{ Spring } & \multicolumn{2}{|c|}{ Summer } & \multicolumn{2}{|c|}{ Fall } & \multicolumn{2}{|c|}{ Winter } & \multicolumn{2}{|c|}{ Annual } \\
\hline & Load & Std err & Load & Std err & Load & Std err & Load & Std err & Load & Std err \\
\hline TN Inputs & 59.6 & 2.6 & 74.1 & 2.3 & 71.3 & 3.6 & 57.5 & 3.0 & 65.7 & 1.9 \\
\hline Exports-Inputs & 28.1 & & 11.0 & & 13.1 & & 25.3 & & 19.5 & \\
\hline NH4 Inputs & 2.60 & 0.62 & 7.89 & 1.8 & 10.6 & 2.8 & 3.57 & 0.96 & 5.95 & 1.1 \\
\hline NO3 Inputs & 0.83 & 0.13 & 0.68 & 0.08 & 1.43 & 0.20 & 1.67 & 0.32 & 1.10 & 0.13 \\
\hline NO3 Out & 3.47 & 0.45 & 1.14 & 0.14 & 2.17 & 0.33 & 5.48 & 0.76 & 3.0 & 0.29 \\
\hline Exports-Inputs & 2.64 & & 0.46 & & 0.74 & & 3.81 & & 1.90 & \\
\hline TP Inputs & 6.07 & 0.36 & 10.6 & 0.59 & 10.3 & 0.71 & 5.96 & 0.43 & 8.22 & 0.33 \\
\hline TDP Exports & 2.18 & 0.14 & 5.57 & 0.33 & 4.64 & 0.34 & 1.66 & 0.12 & 3.54 & 0.16 \\
\hline Exports-Inputs & 0.43 & & 0.11 & & 0.25 & & 0.35 & & 0.28 & \\
\hline Ortho P Inputs & 0.53 & 0.08 & 2.83 & 0.38 & 2.79 & 0.46 & 0.49 & 0.08 & 1.64 & 0.19 \\
\hline Ortho P Exports & 0.91 & 0.13 & 2.75 & 0.37 & 2.67 & 0.46 & 0.83 & 0.15 & 1.78 & 0.19 \\
\hline Exports-Inputs & 0.38 & & -0.08 & & -0.12 & & 0.34 & & 0.14 & \\
\hline Si Inputs & 155 & 10 & 155 & 8.7 & 203 & 18 & 207 & 18 & 177 & 8.1 \\
\hline Si Exports & 451 & 31 & 306 & 20 & 373 & 32 & 515 & 40 & 408 & 20 \\
\hline Exports-Inputs & 296 & & 151 & & 170 & & 308 & & 231 & \\
\hline DOC Inputs & 394 & 12 & 560 & 16 & 432 & 15 & 302 & 11 & 429 & 8.5 \\
\hline
\end{tabular}

in flow. The percentage differences between annual exports and imports were substantially larger for TP than TDP or orthophosphates. Annual TP export averaged $10 \mathrm{~kg} / \mathrm{d}$, and TP input averaged $8.2 \mathrm{~kg} / \mathrm{d}$. The difference, interpreted as the contribution of the Herring River to the total export of TP, was $1.8 \mathrm{~kg} / \mathrm{d}$. Exports and inputs of all forms of phosphorus were highest in summer and fall. Dissolved forms of phosphorus accounted for no more than half of TP in all seasons. Orthophosphate, the most readily available form of phosphorus to algae and aquatic plants, makes up about half of the dissolved phosphorus exported. Other dissolved and particulate forms of phosphorus are subject to decomposition and conversion to more readily available forms.

Exports of total silica exceeded inputs annually and in all seasons (table 5). Annual silica exports averaged $408 \mathrm{~kg} / \mathrm{d}$, and silica inputs averaged $177 \mathrm{~kg} / \mathrm{d}$, indicating a river contribution of $231 \mathrm{~kg} / \mathrm{d}$. Silica exports were highest in winter and spring. Lower silica exports in summer and fall are likely due to reduced river discharge and uptake by phytoplankton in the estuary.

Exports of DOC exceeded inputs annually and in all seasons (table 5). Annual DOC exports averaged $613 \mathrm{~kg} / \mathrm{d}$, and DOC inputs averaged $429 \mathrm{~kg} / \mathrm{d}$, indicating a river contribution of $184 \mathrm{~kg} / \mathrm{d}$. DOC exports, and percentages assumed to be contributed by the river inputs, were highest in spring and summer, and DOC tidal inputs were highest in summer and fall. Higher spring and especially summer exports may indicate more organic matter decomposition in soils, sediments, and water when temperatures are higher. 


\section{Continuous Water-Quality Measurements at Tributaries to the Herring River}

Continuous water-quality measurements at the Bound Brook and Pole Dike Creek tributaries showed substantial seasonal variations during their respective periods of record, late May 2016 to late June 2017 and late May 2016 to late May 2017. Dissolved oxygen (DO) was higher in winter and spring than in summer and fall, whereas $\mathrm{pH}$ and $\mathrm{SpC}$ were consistently higher in summer and lower but much more variable in fall, winter, and spring.

DO was almost always lower in Bound Brook than Pole Dike Creek (fig. 22). DO was generally lower in summer and fall than in winter and spring in both tributaries, which is consistent with lower water temperature in winter and spring. These episodic decreases in DO are presumably driven by algal photosynthesis and microbial respiration dynamics. In winter and spring, DO tended to increase following rainfall events where cumulative rainfall over 1 day, or several consecutive days, was greater than approximately 2 or $3 \mathrm{~cm}$. DO did not respond to rainfall events in the summer and fall.

At Bound Brook in summer, DO reached a maximum in late afternoon and a minimum before sunrise, as expected on the basis of algal photosynthetic production of oxygen during the day and microbial respiration that consumes oxygen during nighttime (fig. 23). At Bound Brook, DO frequently decreased to 0 or near $0 \mathrm{mg} / \mathrm{L}$ in late spring and summer and occasionally in the fall (fig. 22). At Pole Dike Creek, DO approached $0 \mathrm{mg} / \mathrm{L}$ on only one occasion, from November 5 to November 7 in 2016. Summertime diurnal variation in DO in Pole Dike Creek is more complex because it is tidal. At Pole Dike Creek, DO peaks near slack high tides and reaches a minimum near slack low tide, and maximum DO usually occurs between 13:00 and 21:00 hours. In general, the amplitude in diurnal variation in DO was greater at Bound Brook than at Pole Dike Creek.

The $\mathrm{pH}$ was consistently lower at Bound Brook than Pole Dike Creek throughout the year, and the difference was most pronounced during fall and spring (fig. 24). During the fall of 2016, the pH in Bound Brook was typically around 4.5 to 4.7, and at Pole Dike Creek it was generally between 5.5 and 6.0. In many instances, $\mathrm{pH}$ declines were observed for both tributaries following substantial rainfall events (figs. 24 and 25). The lowest $\mathrm{pH}$ recorded was 3.7 following a large rainfall event in early April 2017. The $\mathrm{pH}$ was higher at both tributaries during summer of 2016 (generally between 5.7 and 6.2) than during the following fall, winter, or spring (fig. 24). The higher $\mathrm{pH}$ observed from late May to August in 2016 compared with the period following October of 2017 at Bound Brook may be explained by changes in precipitation and associated runoff. Higher rainfall beginning in the fall of 2016, and continuing through the winter, spring, and summer of 2017, may have resulted in a higher proportion of stream water originating from drainage through surficial marsh soils that are more acidic than stream water originating from groundwater that was likely more prevalent during the drier summer of 2016.

Specific conductance $(\mathrm{SpC})$ was substantially greater throughout the year at the tidally influenced Pole Dike Creek tributary than at Bound Brook (fig. 26). The amplitude of tidal cycle variation in $\mathrm{SpC}$ at Pole Dike Creek was larger in summer and fall than in winter and spring. Decreases in $\mathrm{SpC}$ following substantial rainfall events were observed at both tributaries in winter. The $\mathrm{SpC}$ at Pole Dike Creek responded to tidal variations in a regular pattern, increasing with increasing tide height with a brief lag between peaks (fig. 27). The summer of 2016 was unusually dry, resulting in low freshwater inputs that may have increased the intrusion of brackish water that is tidally affected at the sampling location at Pole Dike Creek. This could account for the higher SpC measured at this location during the summer of 2016 compared with the following fall, winter, and spring. In both tributaries, the minimum $\mathrm{SpC}$ values were higher in winter than in summer. The lower minimums in winter could be a result of the increasing rainfall in late fall and winter, which caused more runoff generation through surface marsh soils, which are more acidic than the deeper groundwater pathways that supplied more recharge during the dry late spring and summer.

Surface-water temperature followed the expected seasonal pattern, with the maximum occurring in late summer and the minimum in midwinter, in both tributaries (fig. 28). Water temperature was higher in Pole Dike Creek than in Bound Brook from late May through early September, but during the following fall, winter, and early spring, temperatures were similar. In the fall of 2016, substantial rainfall events resulted in increased surface-water temperature. The higher water temperature in the summer at Pole Dike Creek may be a result of tidal influence that increases the residence time of stream water and hence solar insolation and heat transfer from the channel banks and benthic sediments. It is also possible that the water in Bound Brook was more influenced by relatively cool groundwater discharge than was the tidally mixed water at Pole Dike Creek. 


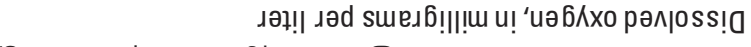

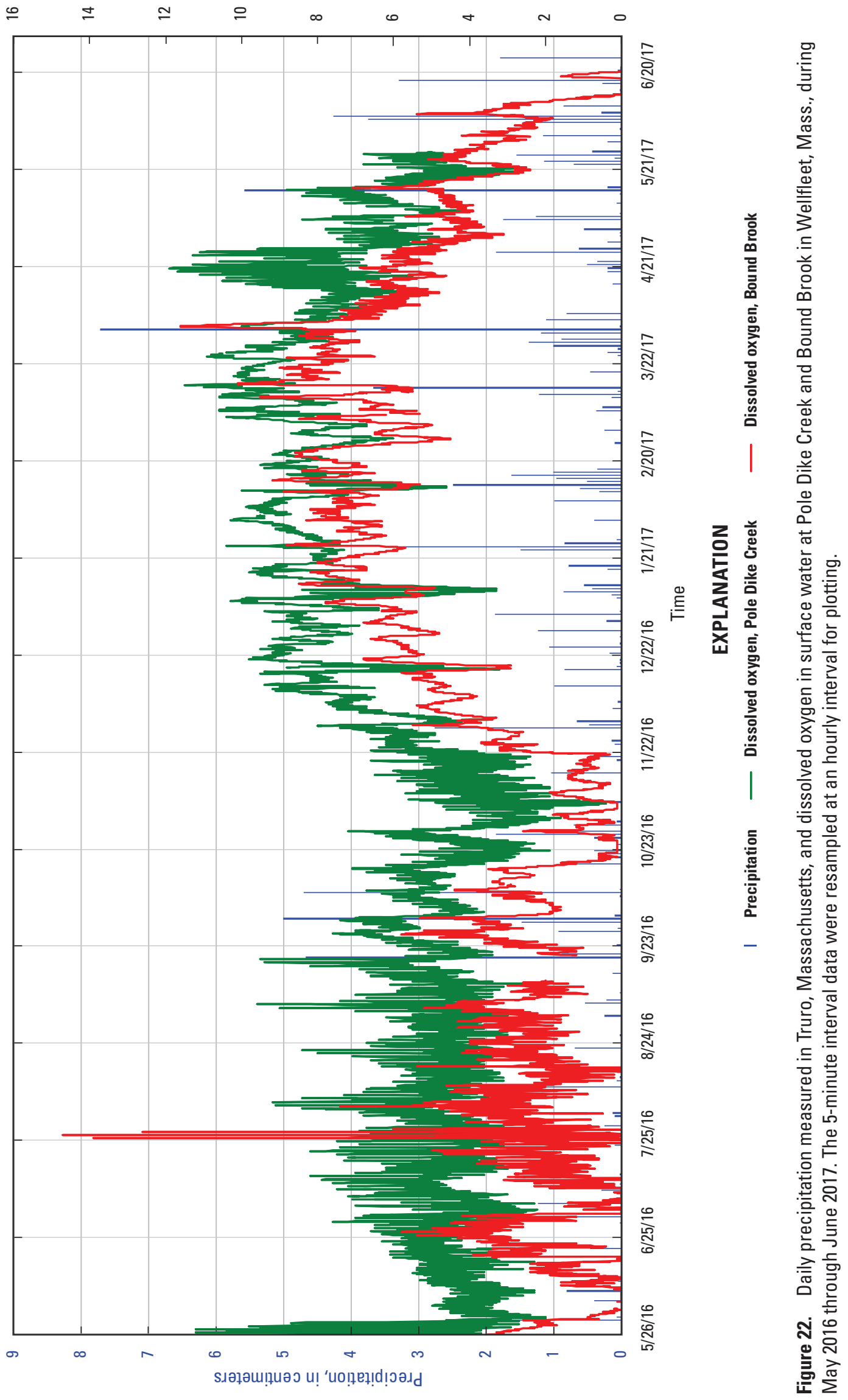




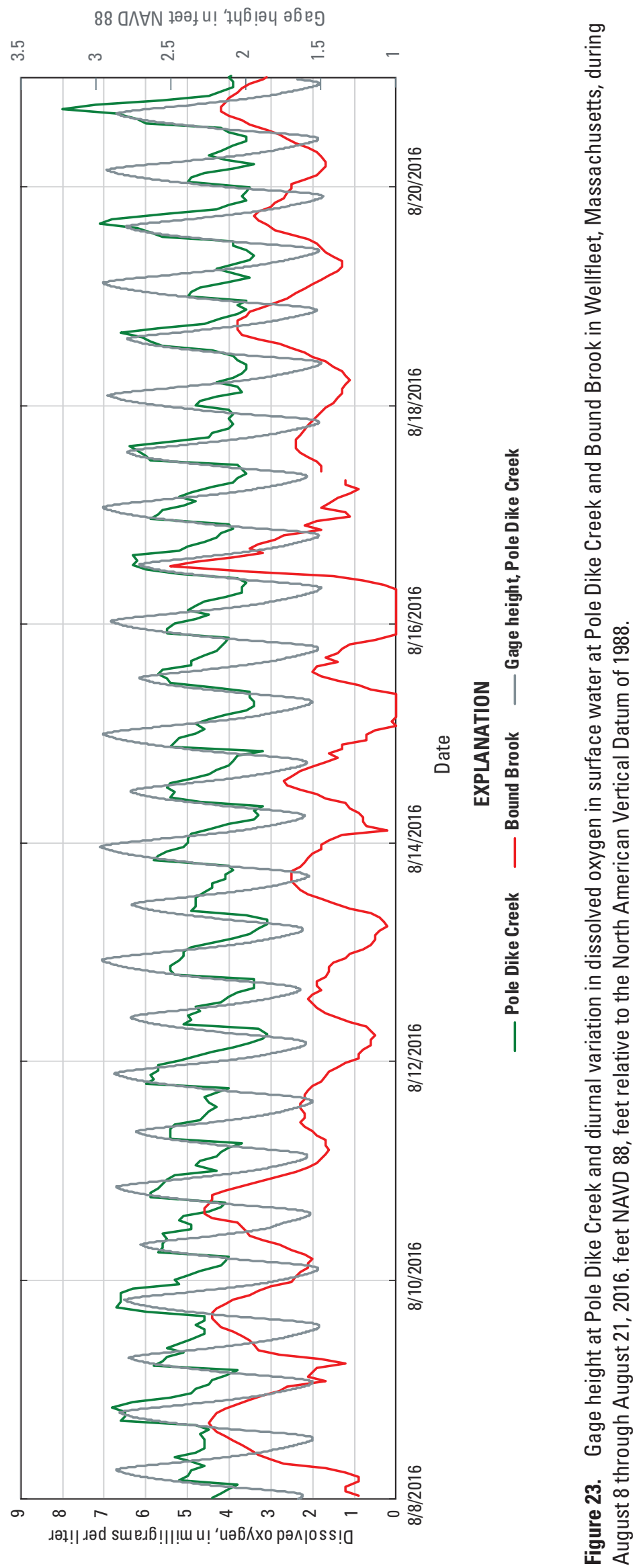



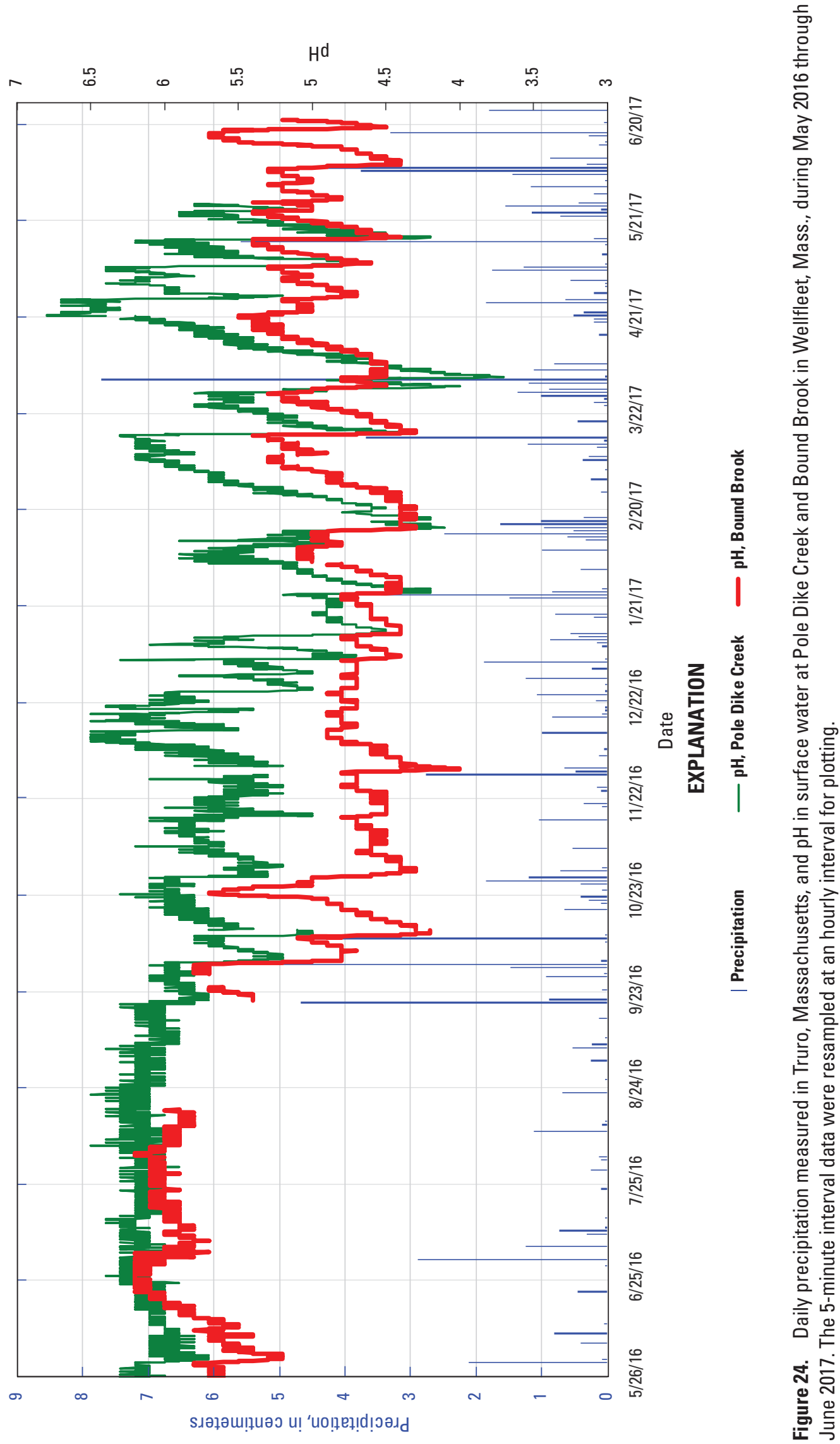


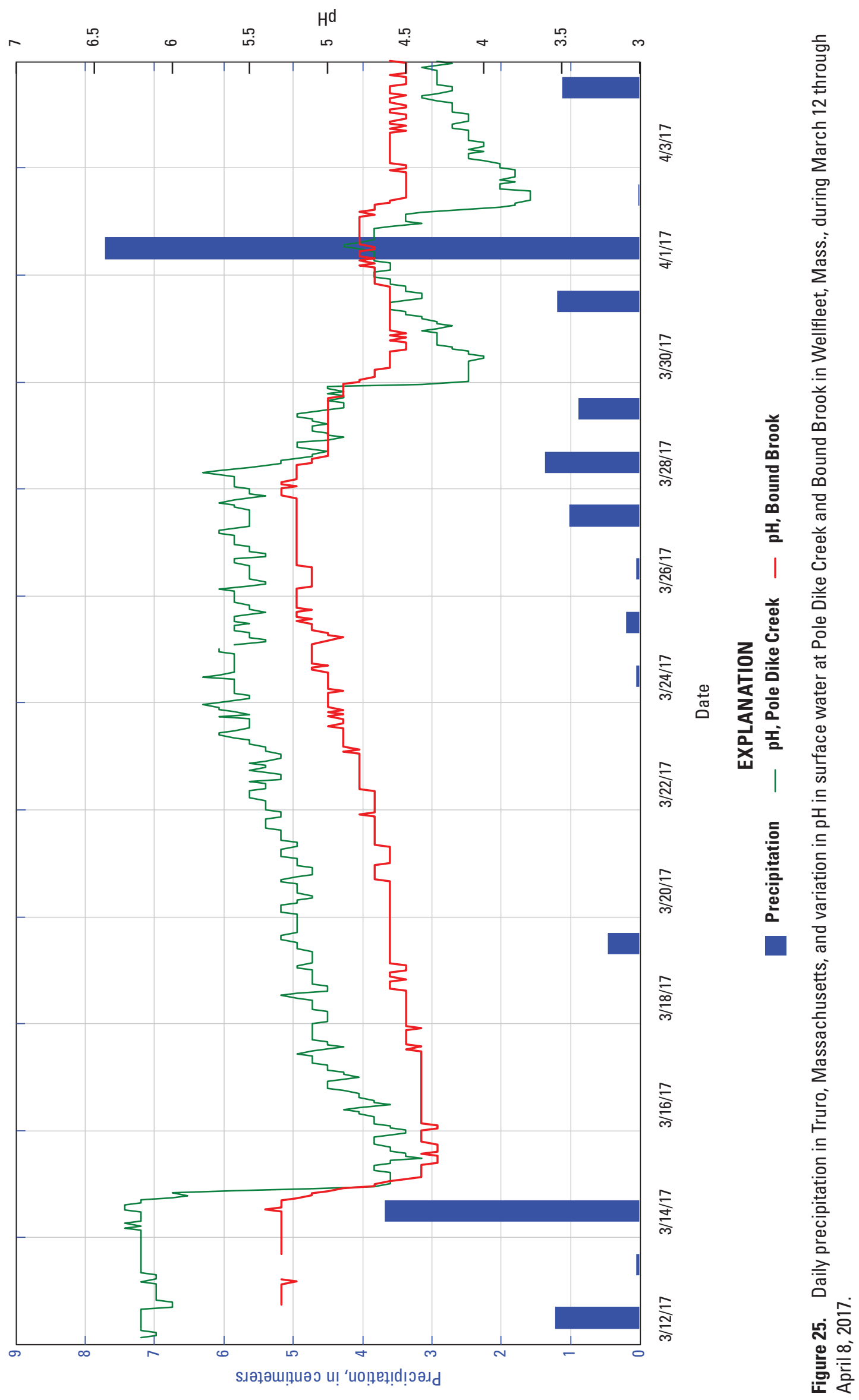




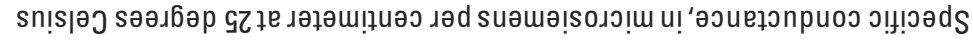
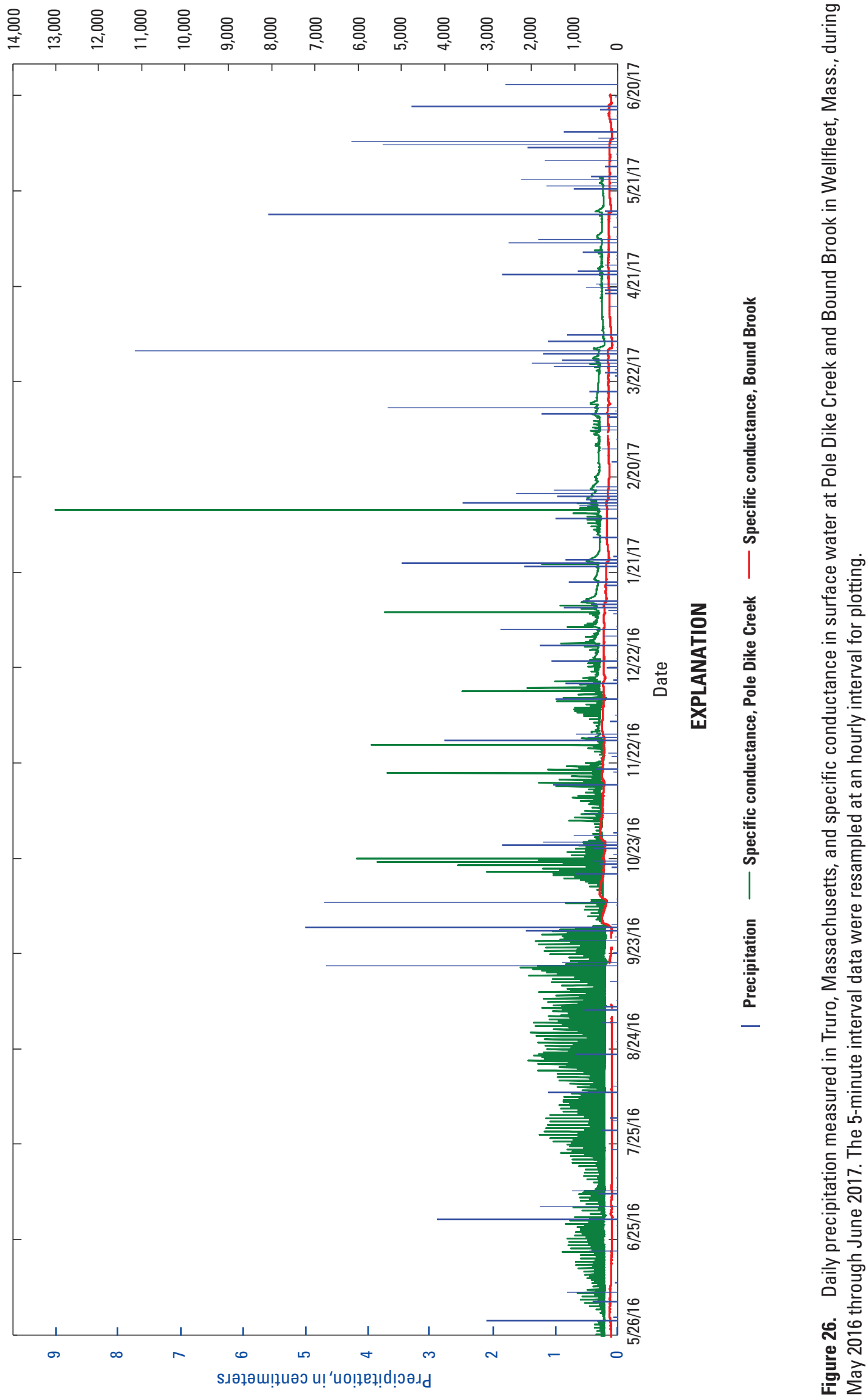


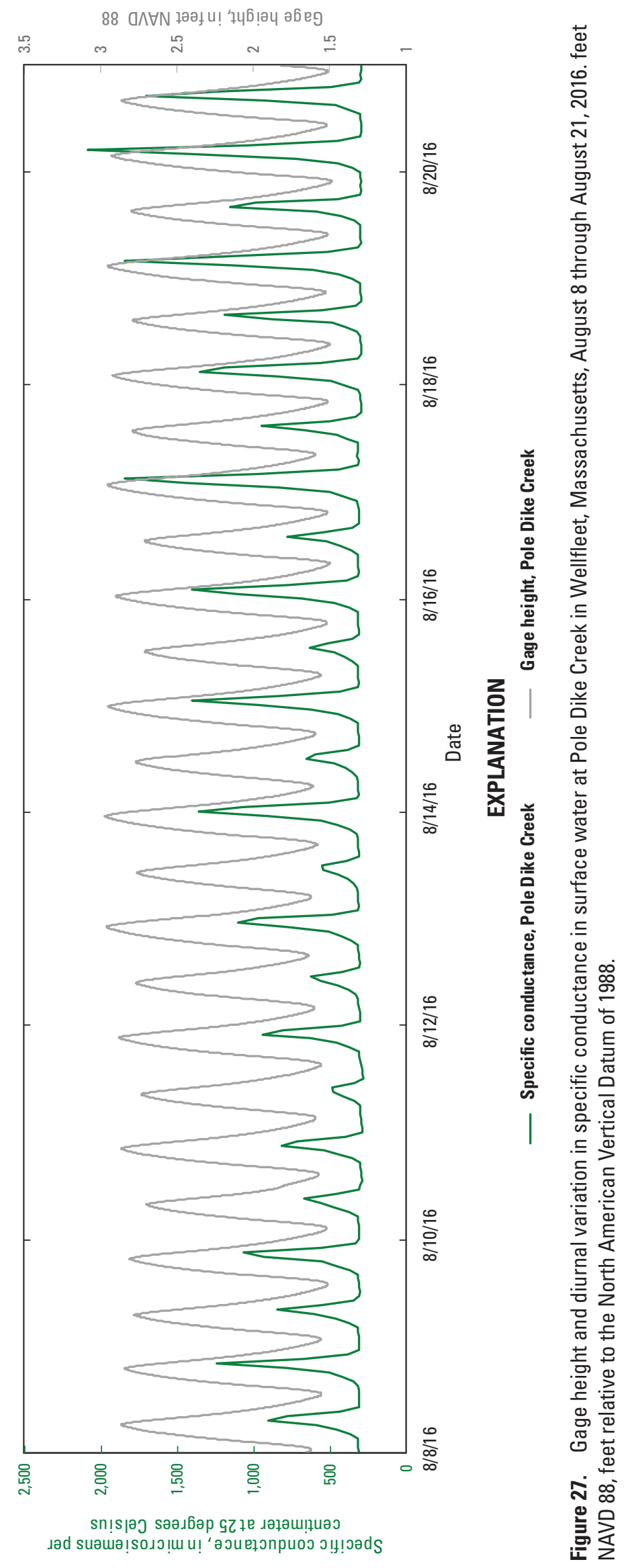




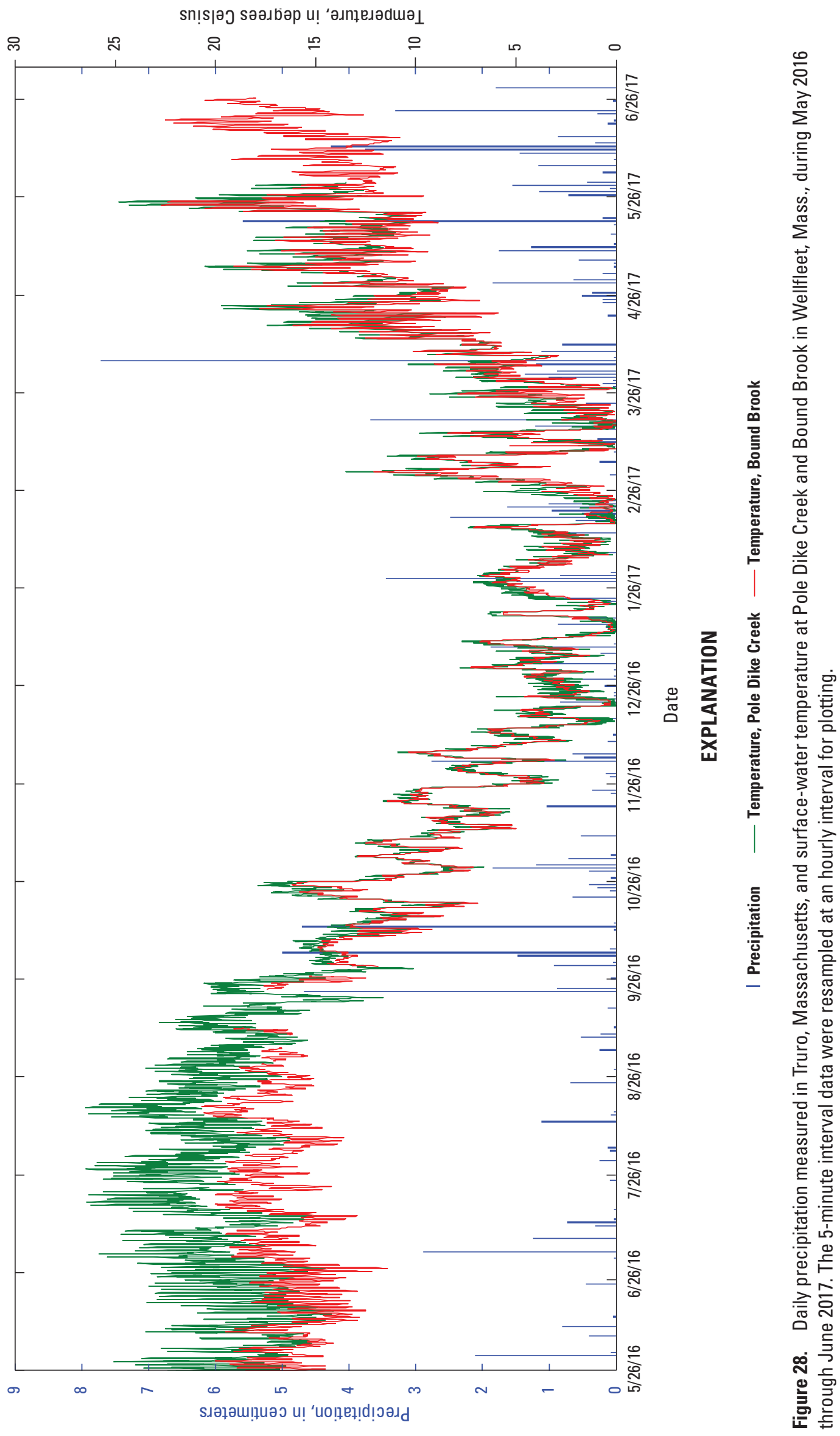




\section{Variation in Nutrient Concentrations in the Tributaries to the Herring River}

Total nitrogen $(\mathrm{TN})$ concentrations in flood and ebb tides in Pole Dike Creek generally were in the range of 3.7 to $17 \mathrm{mg} / \mathrm{L}$ as N (fig. 29), which was an order of magnitude higher than what was observed on the Herring River at Chequessett Neck Road ( 0.25 and $0.60 \mathrm{mg} / \mathrm{L}$ as $\mathrm{N}$ in flood and ebb tides, respectively; fig. 16). The high concentrations of $\mathrm{TN}$ in Pole Dike Creek could be explained by contamination originating from the Wellfleet municipal landfill and septage disposal site located about 220 to $400 \mathrm{~m}$ north of the Pole Dike Creek. This landfill was operated for about 40 years and was closed in 1992 (Godfrey and others, 1999; Massachusetts Department of Environmental Protection, 2005). Nutrient data from some wells adjacent to a landfill and septage disposal site near Orleans, Mass. (on Cape Cod about $20 \mathrm{~km}$ south of the landfill in the Pole Dike Creek Basin), had dissolved inorganic
$\mathrm{N}$ concentrations in the range of 10 to $35 \mathrm{mg} / \mathrm{L}$ as N (DeSimone and Howes, 1995). TP concentrations in flood and ebb tides in Pole Dike Creek generally were in the range of 0.04 to $0.12 \mathrm{mg} / \mathrm{L}$ as $\mathrm{P}$ (fig. 30), which was similar to what was observed at Chequessett Neck Road $(0.02$ and $0.10 \mathrm{mg} / \mathrm{L}$ as $\mathrm{P}$, respectively; fig. 19). In the limited records for TN and TP, there were no systematic differences between flood and ebb tides, and the records were too short to discern any seasonal pattern.

TN concentrations in Bound Brook generally were in the range of 0.8 to $1.4 \mathrm{mg} / \mathrm{L}$ as $\mathrm{N}$ (fig. 31), which was approximately twice as high as the concentrations observed at Chequessett Neck Road (0.25 and $0.60 \mathrm{mg} / \mathrm{L}$ as N; fig. 16). TP concentrations in Bound Brook generally were in the range of 0.05 to $0.15 \mathrm{mg} / \mathrm{L}$ as $\mathrm{P}$ (fig. 31 ), which was similar to what was observed at Chequessett Neck Road (0.02 and $0.10 \mathrm{mg} / \mathrm{L}$ as P; fig. 19). The TN and TP records were too short to discern any seasonal patterns.

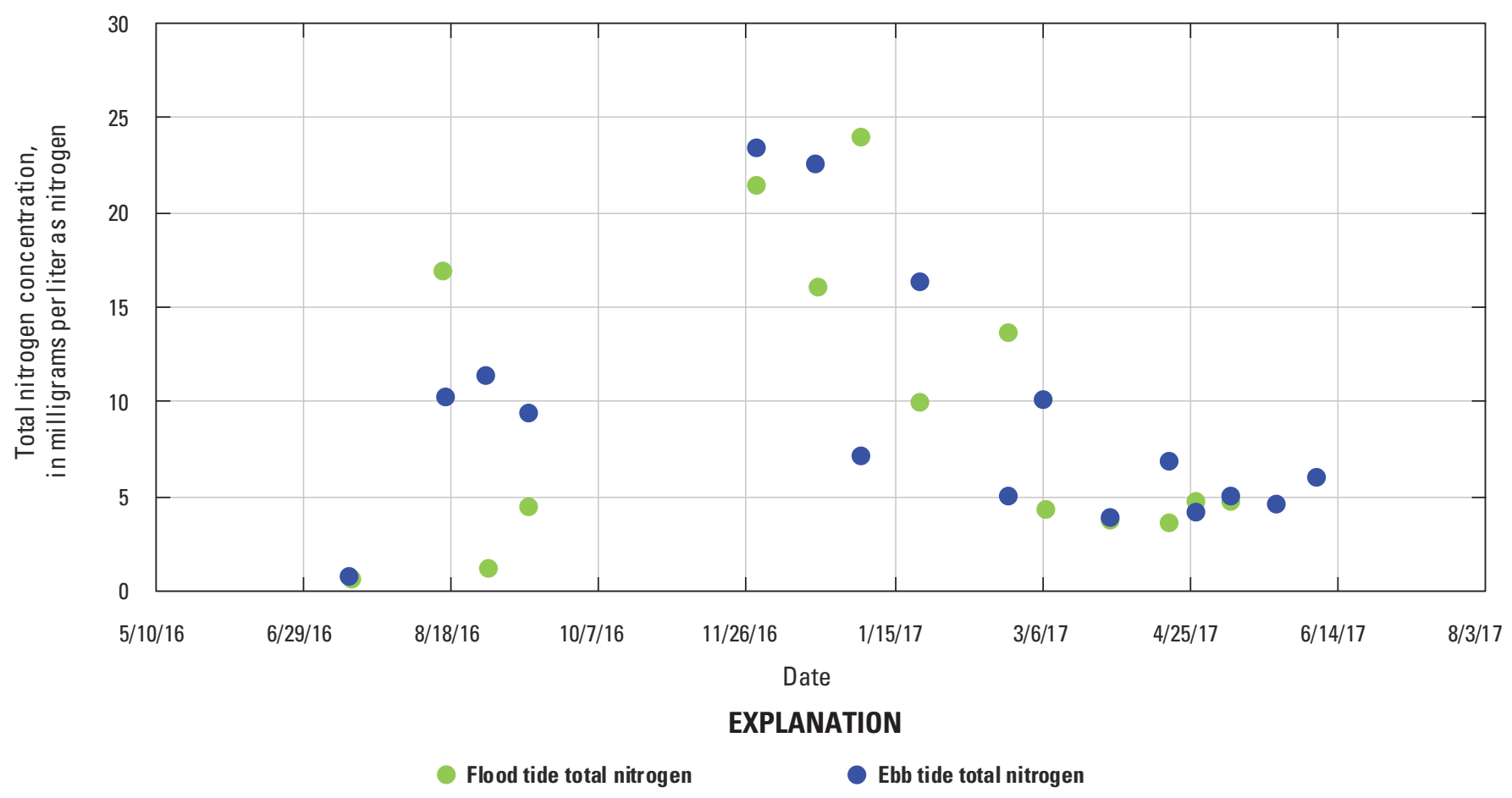

Figure 29. Total nitrogen (unfiltered) concentrations in Pole Dike Creek in Wellfleet, Massachusetts, for flow-weighted composite samples from sequential flood and ebb tides over a 24-hour period, May 2016 to August 2017. 


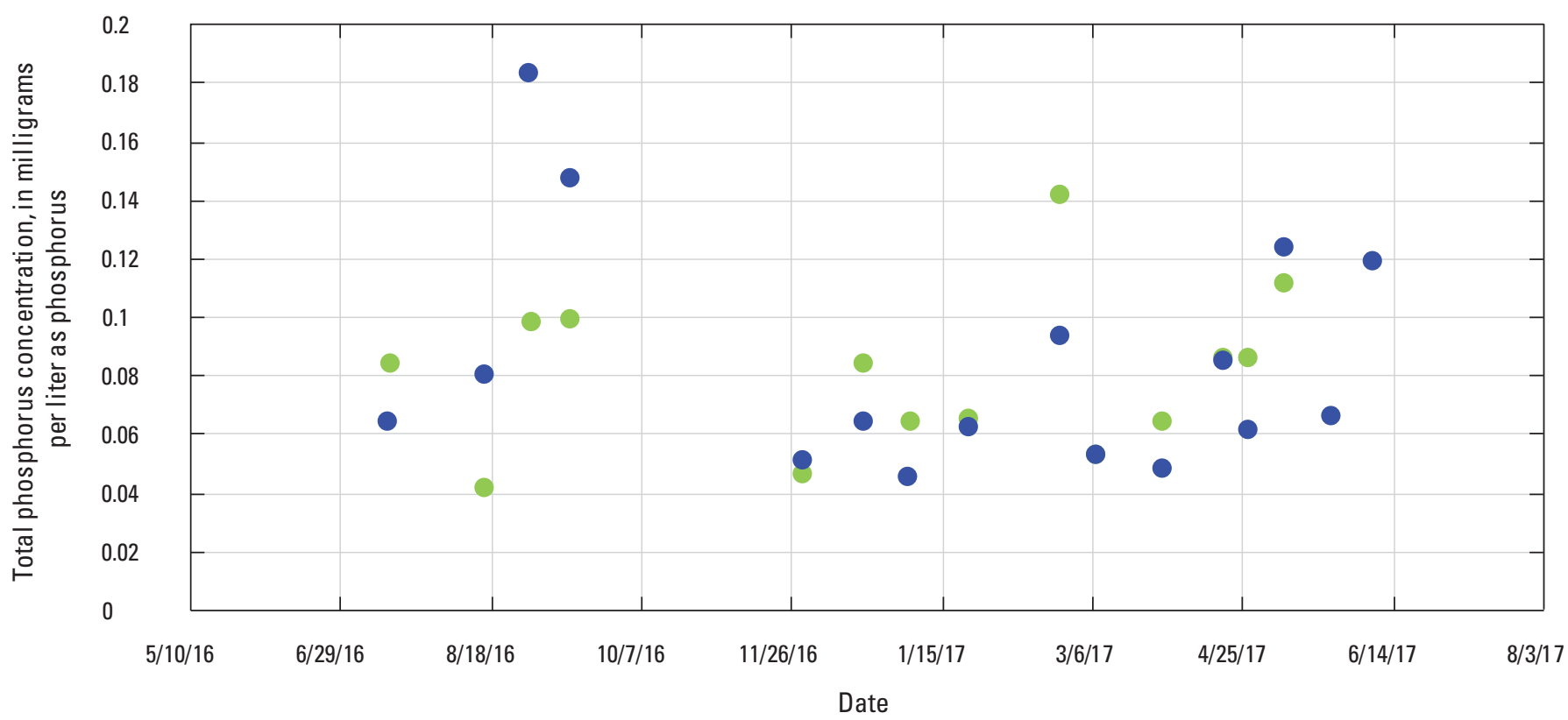

EXPLANATION

Flood tide total phosphorus

Ebb tide total phosphorus

Figure 30. Total phosphorus (unfiltered) concentrations in Pole Dike Creek in Wellfleet, Massachusetts, for flow-weighted composite samples from sequential flood and ebb tides over a 24-hour period, May 2016 to August 2017.

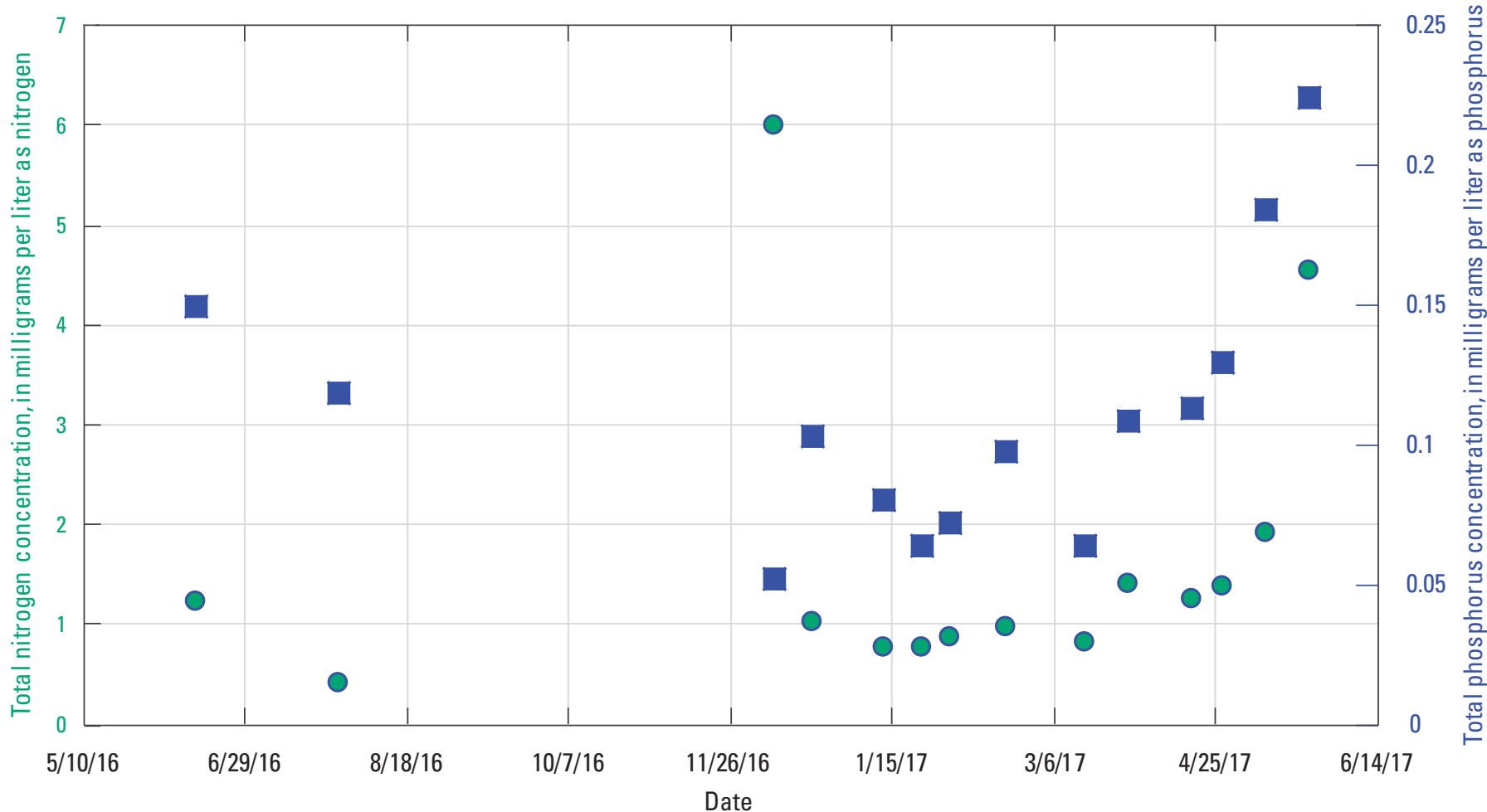

\section{EXPLANATION}

Total nitrogen

Total phosphorus

Figure 31. Total nitrogen and total phosphorus (unfiltered) concentrations in Bound Brook in Wellfleet, Massachusetts, for flow-weighted composite samples over a 24-hour period, May 2016 to June 2017. For Bound Brook some composite samples were not flow weighted because the discharge measurements were compromised by leakage around the weir. 


\section{Summary and Conclusions}

Nutrient concentrations and fluxes across the oceanestuary boundary of the Herring River in Wellfleet, Massachusetts, were assessed by the U.S. Geological Survey, in cooperation with the National Park Service and Friends of Herring River, from November 2015 to September 2017 to characterize environmental conditions prior to future removal of a dike that has restricted saltwater inputs into the watershed for more than 100 years. Flow-weighted concentrations of ammonium $\left(\mathrm{NH}_{4}\right)$, nitrate, and total nitrogen on the ebb tide at the dike on the Herring River generally varied between 0.01 and $0.1,0.003$ and 0.03 , and 0.3 and 0.7 milligram per liter (mg/L) as nitrogen, respectively. Flow-weighted concentrations of orthophosphate, total dissolved phosphorus, and total phosphorus on the ebb tide generally varied between 0.002 and $0.02,0.003$ and 0.06 , and 0.03 and $0.1 \mathrm{mg} / \mathrm{L}$ as phosphorus, respectively. Flow-weighted concentrations of silicate and dissolved organic carbon on the ebb tide generally varied between 0.08 and $3.0 \mathrm{mg} / \mathrm{L}$ as silica and 1.7 and $5.6 \mathrm{mg} / \mathrm{L}$ as carbon, respectively. Ebb tide concentrations of nitrate were highest in winter and lowest in summer. By contrast, ebb tide concentrations of phosphorus species were highest in late summer and early fall and lowest in winter. Silica and dissolved organic carbon did not exhibit systematic variation in seasonal concentrations.

Continuous measurements of dissolved oxygen, $\mathrm{pH}$, specific conductance, and water temperature were recorded from late May 2016 through late May 2017 in Pole Dike Creek and from late May 2016 through late June 2017 in Bound Brook, two tributaries to the Herring River. Total nitrogen and total phosphorus measurements were recorded for discrete and composite samples collected periodically from flood and ebb tides at Pole Dike Creek from late May 2016 through midJune 2017. Total nitrogen and total phosphorus measurements were recorded for discrete and composite samples collected periodically from Bound Brook from late May 2016 through late May 2017.

There was uncertainty in estimates of nutrient fluxes, but the LOADEST estimated fluxes indicated that annual (and in almost all cases seasonal) exports (ebb tides) exceeded inputs (flood tides). The differences (where exports exceed inputs) are thought to represent the contribution of the Herring River watershed as a source of these constituents to Wellfleet Harbor. The absolute values of the nutrient fluxes and the differences (Herring River contribution) have some uncertainty. Ebb tide concentrations of $\mathrm{NH}_{4}$, nitrate, total nitrogen, and silica were positively correlated with antecedent cumulative 7-day precipitation. These positive correlations indicate that precipitation likely results in the mobilization and transport of these constituents in excess of base-flow conditions.

Additional (future) prerestoration water-quality and discharge data would provide a more comprehensive understanding of the range of natural variability in nutrient concentrations and loads in response to variable hydrologic conditions. Alternative methods (potentially using different monitoring equipment, like upward-looking acoustic velocity sensors deployed on the base of the culvert and water-level gages installed in different locations) could result in an improved discharge record, and, if combined with concurrent waterquality data, the uncertainties in the estimation of nutrient fluxes could be reduced. A longer sampling period that encompasses more natural variation in hydrologic conditions would improve understanding of future variations in nutrient fluxes. The range of nutrient concentrations reported in this study reflects the hydrologic conditions during the study period. If the hydrologic conditions after dike removal are substantially different from those during the study period, then it may be difficult to distinguish between natural variability and response to the dike removal. The followup studies mentioned in the introduction will provide a more comprehensive understanding of natural variability under a broader range of hydrologic conditions.

\section{References Cited}

Aquatic Informatics, Inc., 2019, AQUARIUS Time-Series: Aquatic Informatics, Inc., web page, accessed November 4, 2019, at https://aquaticinformatics.com/products/aquarius/ aquarius-time-series/.

Carlson, C.S., Masterson, J.P., Walter, D.A., and Barbaro, J.R., 2017a, Development of simulated groundwater-contributing areas to selected streams, ponds, coastal water bodies, and production wells in the Plymouth-Carver region and Cape Cod, Massachusetts: U.S. Geological Survey Data Series 1074, 17 p., accessed June 2, 2018, at https://doi.org/ $10.3133 / \mathrm{ds} 1074$.

Carlson, C.S., Masterson, J.P., Walter, D.A., and Barbaro, J.R., 2017b, Simulated groundwater-contributing areas to selected streams, ponds, coastal water bodies, and production wells, Plymouth-Carver region and Cape Cod, Massachusetts: U.S. Geological Survey data release, accessed June 2, 2018, at https://doi.org/ 10.5066/F7V69H2Z.

Chaffee, C., Ferguson, W., and Ekberg, M.C., 2012, Salt marsh restoration in Rhode Island, in Roman, C.T., and Burdick, D.M., eds., Tidal marsh restoration-A synthesis of science and management: Washington, D.C., Island Press/Center for Resource Economics, p. 157-164. [Also available at https://doi.org/10.5822/978-1-61091-229-7_9.]

Cohn, T.A., 1988, Adjusted maximum likelihood estimation of the moments of lognormal populations from type I censored samples: U.S. Geological Survey Open-File Report 88-350, 34 p. [Also available at https://doi.org/10.3133/ofr88350.] 
Cohn, T.A., Gilroy, E.J., and Baier, W.G., 1992, Estimating fluvial transport of trace constituents using a regression model with data subject to censoring, in Proceedings of the Section on Statistics and the Environment, Joint Statistical Meetings; Boston, Mass., August 9-13, 1992: Alexandria, Va., American Statistical Association, p. 142-152.

Cornelis, J.T., Delvaux, B., Georg, R.B., Lucas, Y., Ranger, J., and Opfergelt, S., 2011, Tracing the origin of dissolved silicon transferred from various soil-plant systems towards rivers-A review: Biogeosciences, v. 8, no. 1, p. 89-112. [Also available at https://doi.org/10.5194/bg-8-89-2011.]

Cornelis, J.T., Ranger, J., Iserentant, A., and Delvaux, B., 2010, Tree species impact the terrestrial cycle of silicon through various uptakes: Biogeochemistry, v. 97, no. 2-3, p. 231-245. [Also available at https://doi.org/10.1007/ s10533-009-9369-x.]

DeSimone, L.A., and Howes, B.L., 1995, Hydrogeologic, water-quality, and biogeochemical data collected at a septage-treatment facility, Orleans, Cape Cod, Massachusetts, October 1988 through December 1992: U.S. Geological Survey Open-File Report 95-439, 73 p. [Also available at https://doi.org/10.3133/ofr95439.]

Fletcher, P.C., 1993, Soil survey of Barnstable County: Massachusetts, U.S. Department of Agriculture, Soil Conservation Service, $211 \mathrm{p}$.

Garrett, C., 1972, Tidal resonance in the Bay of Fundy and Gulf of Maine: Nature, v. 238, p. 441-443. [Also available at https://doi.org/10.1038/238441a0.]

Garvine, R.W., 1987, Tidal height model of the Herring River, appendix 5 of Roman, C.T., 1987, An evaluation of alternatives for estuarine restoration managementThe Herring River ecosystem (Cape Cod National Seashore): New Brunswick, N.J., National Park Service Cooperative Research Unit, Rutgers University, accessed October 6, 2017, at https://ia800302.us.archive.org/9/items/ evaluationofalte00roma/evaluationofalte00roma.pdf.

Godfrey, P.J., Galluzzo, K., Price, N., Portnoy, J.W., Reynolds, M., Vana-Miller, D., and National Park Service, 1999, Water resources management plan-Cape Cod National Seashore, Massachusetts: Wellfleet, Mass., National Park Service, Cape Cod National Seashore, 252 p.

Herring River Technical Committee, 2007, Herring River Tidal Restoration Project, conceptual restoration plan, October 2007: Prepared by the Herring River Technical Committee, with technical support by ENSR/AECOM, for Towns of Wellfleet and Truro and the Cape Cod National Seashore, [variously paged]. [Also available at http://www.friendsofherringriver.org/Files/HR_CRP FullDocumnet.pdf.]
Hirsch, R.M., 2014, Large biases in regression-based constituent flux estimates - Causes and diagnostic tools: Journal of the American Water Resources Association, v. 50, no. 6, p. 1401-1424. [Also available at https://doi.org/10.1111/ jawr.12195.]

Huntington, T.G., and Spaetzel, A.B., 2020, Tidal daily discharge and quality assurance data supporting an assessment of water quality and discharge in the Herring River, Wellfleet, Massachusetts, November 2015-September 2017: U.S. Geological Survey data release, https://doi.org/ 10.5066/P9BKW4BX.

LeBlanc, D.R., Guswa, J.H., Frimpter, M.H., and Londquist, C.J., 1986, Ground-water resources of Cape Cod, Massachusetts [sheet 2]: U.S. Geological Survey Hydrologic Atlas HA-692, 4 sheets.

Levesque, V.A., and Oberg, K.A., 2012, Computing discharge using the index velocity method: U.S. Geological Survey Techniques and Methods, book 3, chap. A23, 148 p. [Also available at https://doi.org/10.3133/tm3A23.]

Massachusetts Department of Environmental Protection, 2005, Inactive or closed solid waste landfills, May 2005: Boston, Mass., Massachusetts Department of Environmental Protection, Bureau of Waste Prevention, accessed January 19, 2006, at https://www.mass.gov/dep/recycle/ solid/swfacil.htm.

Masterson, J.P., 2004, Simulated interaction between freshwater and saltwater and effects of ground-water pumping and sea-level change, Lower Cape Cod aquifer system, Massachusetts: U.S. Geological Survey Scientific Investigations Report 2004-5014, 72 p. [Also available at https://doi.org/10.3133/sir20045014.]

Mueller, D.S., Wagner, C.R., Rehmel, M.S., Oberg, K.A., and Rainville, F., 2013, Measuring discharge with acoustic Doppler current profilers from a moving boat (ver. 2.0, December 2013): U.S. Geological Survey Techniques and Methods, book 3, chap. A22, 95 p. [Also available at https://doi.org/10.3133/tm3A22.]

National Atmospheric Deposition Program, 2018, NTN site MA01: National Atmospheric Deposition Program annual precipitation data, accessed November 26, 2018, at https://nadp.slh.wisc.edu/data/sites/siteDetails.aspx?net= NTN\&id=MA01.

National Park Service, Town of Wellfleet, Mass., Town of Truro, and Herring River Restoration Committee, 2016, Herring River restoration project, final environmental impact statement/environmental impact report, May 2016: National Park Service Environmental Impact Statement/Report, 446 p., accessed October 6, 2017, at https://parkplanning.nps.gov/document.cfm?parkID= $217 \&$ projectID $=18573 \&$ documentID $=73471$. 
Natural Resources Conservation Service, 2018, Web soil survey: U.S. Department of Agriculture, Natural Resources Conservation Service data application, accessed July 20, 2018, at https://websoilsurvey.sc.egov.usda.gov/App/ HomePage.htm.

Patton, C.J., and Kryskalla, J.R., 2003, Methods of analysis by the U.S. Geological Survey National Water Quality Laboratory-Evaluation of alkaline persulfate digestion as an alternative to Kjeldahl digestion for determination of total and dissolved nitrogen and phosphorus in water: U.S. Geological Survey Water-Resources Investigations Report 03-4174, 33 p. [Also available at https://doi.org/ 10.3133/wri034174.]

Portnoy, J.W., 1991, oxygen depletion in a diked New England estuary: Estuaries, v. 14, no. 2, p. 122-129. [Also available at https://doi.org/10.2307/1351685.]

Portnoy, J.W., 1999, Salt marsh diking and restorationBiogeochemical implications of altered wetland hydrology: Environmental Management, v. 24, no. 1, p. 111-120. [Also available at https://doi.org/10.1007/s002679900219.]

Portnoy, J.W., and Allen, J.R., 2006, Effects of tidal restrictions and potential benefits of tidal restoration on fecal coliform and shellfish-water quality: Journal of Shellfish Research, v. 25, no. 2, p. 609-617. [Also available at https://doi.org/10.2983/0730-8000(2006)25[609:EOTR AP]2.0.CO;2.]

Portnoy, J.W., and Giblin, A.E., 1997a, Biogeochemical effects of seawater restoration to diked salt marshes: Ecological Applications, v. 7, no. 3, p. 1054-1063. [Also available at https://doi.org/10.1890/1051-0761(1997)007[1054:BEOS $\mathrm{RT}] 2.0 . \mathrm{CO} ; 2$.

Portnoy, J.W., and Giblin, A.E., 1997b, Effects of historic tidal restrictions on salt marsh sediment chemistry: Biogeochemistry, v. 36, no. 3, p. 275-303. [Also available at https://doi.org/10.1023/A:1005715520988.]

Roman, C.T., 1987, Herring River estuary-Historic vegetation development, appendix 1 of An evaluation of alternatives for estuarine restoration management-The Herring River ecosystem (Cape Cod National Seashore): New Brunswick, N.J., National Park Service Cooperative Research Unit, Rutgers University, accessed October 6, 2017, at https://ia800302.us.archive.org/9/items/ evaluationofalte00roma/evaluationofalte00roma.pdf.

Roman, C.T., and Burdick, D.M., 2012, Tidal marsh restoration-A synthesis of science and management: Washington, D.C., Island Press, 432 p.
Roman, C.T., Garvine, R.W., and Portnoy, J.W., 1995, Hydrologic modeling as a predictive basis for ecological restoration of salt marshes: Environmental Management, v. 19, no. 4, p. 559-566. [Also available at https://doi.org/ 10.1007/BF02471967.]

Ruhl, C.A., and Simpson, M.R., 2005, Computation of discharge using the index-velocity method in tidally affected areas: U.S. Geological Survey Scientific Investigations Report 2005-5004, 31 p., accessed July 16, 2018, at https://pubs.usgs.gov/sir/2005/5004/sir20055004.pdf.

Runkel, R.L., 2013, Revisions to LOADEST, April 2013: U.S. Geological Survey documentation, 6 p., accessed May 1, 2018, at https://water.usgs.gov/software/ loadest/doc/.

Runkel, R.L., Crawford, C.G., and Cohn, T.A., 2004, Load Estimator (LOADEST) - A FORTRAN program for estimating constituent loads in streams and rivers: U.S. Geological Survey Techniques and Methods, book 4, chap. A5, 69 p., accessed June 1, 2018, at https://pubs.er.usgs.gov/publication/tm4A5.

Sommer GmbH, 2014, RG-30, RG-30a, velocity measurement system, user manual (ver. V02, July 29, 2014): Sommer GmbH user manual, accessed February 6, 2019, at https://measureitpdf.blob.core.windows.net/pdf/pdf_ datablad/sommer/sommer_rg-30_manual.pdf.

Soukup, M.A., and Portnoy, J.W., 1986, Impacts from mosquito control-induced sulphur mobilization in a Cape Cod estuary: Environmental Conservation, v. 13, no. 1, p. 47-50. [Also available at https://doi.org/10.1017/ S0376892900035864.].

Struyf, E., and Conley, D.J., 2012, Emerging understanding of the ecosystem silica filter: Biogeochemistry, v. 107, no. 1-3, p. 9-18. [Also available at https://doi.org/10.1007/s10533011-9590-2.]

Sugimura, Y., and Suzuki, Y., 1988, A high-temperature catalytic oxidation method for the determination of nonvolatile dissolved organic carbon in seawater by direct injection of a liquid sample: Marine Chemistry, v. 24, no. 2, p. 105-131. [Also available at https://doi.org/10.1016/03044203(88)90043-6.]

U.S. Environmental Protection Agency, 1993, Method 350.1: Determination of ammonia nitrogen by semi-automated colorimetry (rev. 2.0, August 1993): U.S. Environmental Protection Agency analytical method, $15 \mathrm{p}$.

U.S. Geological Survey, 2015, The StreamStats program: U.S. Geological Survey web page, accessed July 19, 2018, at https://water.usgs.gov/osw/streamstats/. 
U.S. Geological Survey, 2019, USGS water data for the Nation: U.S. Geological Survey National Water Information System database, accessed November 11, 2019, at https://doi.org/10.5066/F7P55KJN.

U.S. Geological Survey, [variously dated], National field manual for the collection of water-quality data: U.S. Geological Survey Techniques of Water-Resources Investigations, book 9, chaps. A1-A10, accessed July 18, 2017, at https://pubs.water.usgs.gov/twri9A.

Wagner, R.J., Boulger, R.W., Jr., Oblinger, C.J., and Smith, B.A., 2006, Guidelines and standard procedures for continuous water-quality monitors - Station operation, record computation, and data reporting: U.S. Geological Survey Techniques and Methods, book 1, chap. D3, 51 p., 8 attachments, accessed April 10, 2015, at https://pubs.er.usgs.gov/ publication/tm1D3.

Warren, R.S., Fell, P.E., Rozsa, R., Brawley, A.H., Orsted, A.C., Olson, E.T., Swamy, V., and Niering, W.A., 2002, Salt marsh restoration in Connecticut -20 years of science and management: Restoration Ecology, v. 10, no. 3, p. 497-513. [Also available at https://doi.org/10.1046/ j.1526-100X.2002.01031.x.]

Western Regional Climate Center, 2018, Weather data for the Wellfleet, Massachusetts, monitoring site: Western Regional Climate Center RAWS USA Climate Archive, accessed April 12, 2018, at https://raws.dri.edu/cgi-bin/ rawMAIN.pl?ncMCAP.
Woods Hole Group, 2012, Herring River hydrodynamic modeling: East Falmouth, Mass., Final Comprehensive Report prepared for the Herring River Restoration Committee, accessed October 2, 2017, at http://www.friendsofherring river.org/Files/HerringRiverFULLFinalReport.pdf.

Zhang, J.-Z., and Berberian, G.A., 1997, Method 366.0Determination of dissolved silicate in estuarine and coastal waters by gas segmented continuous flow colorimetric analysis: U.S. Environmental Protection Agency EPA/600/R-15/010, 13 p.

Zhang, J.-Z., Ortner, P.B., and Fischer, C.J., 1997, EPA Method 353.4 - Determination of nitrate and nitrite in estuarine and coastal waters by gas segmented continuous flow colorimetric analysis (rev. 2.0, September 1997): U.S. Environmental Protection Agency EPA/600/R-15/012, 20 p.

Zimmerman, C.F., and Keefe, C.W., 1997, Method 365.5Determination of orthophosphate in estuarine and coastal waters by automated colorimetric analysis (rev. 1.4, September 1997): U.S. Environmental Protection Agency EPA/600/R-15/011, 9 p. 



\section{Appendix 1. LOADEST Models Selected and Bias Statistics for Estimating Nutrient Fluxes Across the Ocean-Estuary Boundary on the Herring River at Chequessett Neck Road, Wellfleet, Massachusetts}

\section{References Cited}

Runkel, R.L., 2013, Revisions to LOADEST, April 2013: U.S. Geological Survey documentation, 6 p., accessed May 1, 2018, at https://water.usgs.gov/software/ loadest/doc/.
Runkel, R.L., Crawford, C.G., and Cohn, T.A., 2004, Load Estimator (LOADEST) - A FORTRAN program for estimating constituent loads in streams and rivers: U.S. Geological Survey Techniques and Methods, book 4, chap. A5, 69 p., accessed June 1, 2018, at https://pubs.er.usgs.gov/publication/tm4A5.

Table 1.1. LOADEST regression models used in this study and bias statistics for each model.

[Bias statistics and model numbers from Runkel and others (2004) and Runkel (2013). Constituents ("In" indicates flood tide, "Out" indicates ebb tide): $\mathrm{TN}$, total nitrogen; $\mathrm{NH}_{4}$, ammonium; $\mathrm{NO}_{3}$, nitrate; TP, total phosphorus; TDP, total dissolved phosphorus; Ortho P, orthophosphate; Si, silica; DOC, dissolved organic carbon. Rsq, coefficient of determination; PLR, partial load ratio; PCR, partial concentration ratio; $B_{p}$, load bias; E, Nash-Sutcliffe efficiency index; NA, not applicable]

\begin{tabular}{|c|c|c|c|c|c|}
\hline Constituent & Model & Rsq, in percent & Load bias, ${ }^{1}$ in percent & PLR or PCR² & $E^{3}$ \\
\hline TN In & 8 & 35.25 & -0.094 & 0.999 & 0.284 \\
\hline TN Out & 9 & 24 & -0.804 & 0.992 & 0.175 \\
\hline NH4 Out & NA & NA & NA & NA & NA \\
\hline NO3 In & 8 & 45.46 & 2.98 & 1.03 & 0.285 \\
\hline TP Out & 4 & 32.52 & 0.346 & 1.003 & 0.295 \\
\hline TDP In & 4 & 87.78 & -1.370 & 0.986 & 0.839 \\
\hline TDP Out & 4 & 81.1 & 1.396 & 1.014 & 0.778 \\
\hline Ortho P In & 4 & 66.08 & 8.686 & 1.087 & 0.646 \\
\hline DOC In & 9 & 78.11 & -0.325 & 0.997 & 0.690 \\
\hline DOC Out & 9 & 64.88 & -0.999 & 0.99 & 0.503 \\
\hline
\end{tabular}

1Positive values indicate overestimation, and negative values indicate underestimation.

${ }^{2}$ Sum of estimated loads(concentrations) divided by sum of observed loads(concentrations). Values $>1$ indicate overestimation; values $<1$ indicate underestimation. $\mathrm{PLR}=\left(B_{p}+100\right) / 100 ; \mathrm{PCR}=\left(B_{p}+100\right) / 100$.

${ }^{3} \mathrm{E}$ ranges from -infinity to 1.0 . $\mathrm{E}=1$ is a perfect fit to observed data. 


\section{Appendix 2. LOADEST Regression Equations Used To Estimate Nutrient Loads Across the Ocean-Estuary Boundary on the Herring River at Chequessett Neck Road, Wellfleet, Massachusetts}

Table 2.1. LOADEST regression models used in this study.

[Modified from Runkel and others (2004, table 7). a, model coefficient; $\ln Q=\ln ($ streamflow) - center of $\ln ($ streamflow); dtime $=$ decimal time - center of decimal time]

\begin{tabular}{cl}
\hline Model number & \multicolumn{1}{c}{ Regression model } \\
\hline 4 & $a_{0}+a_{1} \ln Q+a_{2} \sin (2 \pi d t i m e)+a_{3} \cos (2 \pi d t i m e)$ \\
6 & $a_{0}+a_{1} \ln Q+a_{2} \ln Q^{2}+a_{3} \sin (2 \pi d t i m e)+a_{4} \cos (2 \pi d t i m e)$ \\
7 & $a_{0}+a_{1} \ln Q+a_{2} \sin (2 \pi d t i m e)+a_{3} \cos (2 \pi d t i m e)+a_{4} d t i m e$ \\
8 & $a_{0}+a_{1} \ln Q+a_{2} \ln Q^{2}+a_{3} \sin (2 \pi d t i m e)+a_{4} \cos (2 \pi d t i m e)+a_{5} d t i m e$ \\
9 & $a_{0}+a_{1} \ln Q+a_{2} \ln Q^{2}+a_{3} \sin (2 \pi d t i m e)+a_{4} \cos (2 \pi d t i m e)+a_{5}$ dtime $+a_{6} d t i m e^{2}$ \\
\hline
\end{tabular}


Table 2.2. LOADEST regression model coefficients used in this study.

[Model coefficients and associated $p$-values from LOADEST model regression analysis. Regression models are shown in table 2.1. Separate models were derived for each constituent for flood tides and for ebb tides. In the exponential notation used, E means "multiplied by 10 to the power of." Constituents ("In" indicates flood tide, "Out" indicates ebb tide): $\mathrm{DOC}$, dissolved organic carbon; $\mathrm{NH}_{4}$, ammonium; $\mathrm{NO}_{3}$, nitrate; Ortho P, orthophosphate; Si, silica; TDP, total dissolved phosphorus; TN, total nitrogen; TP, total phosphorus]

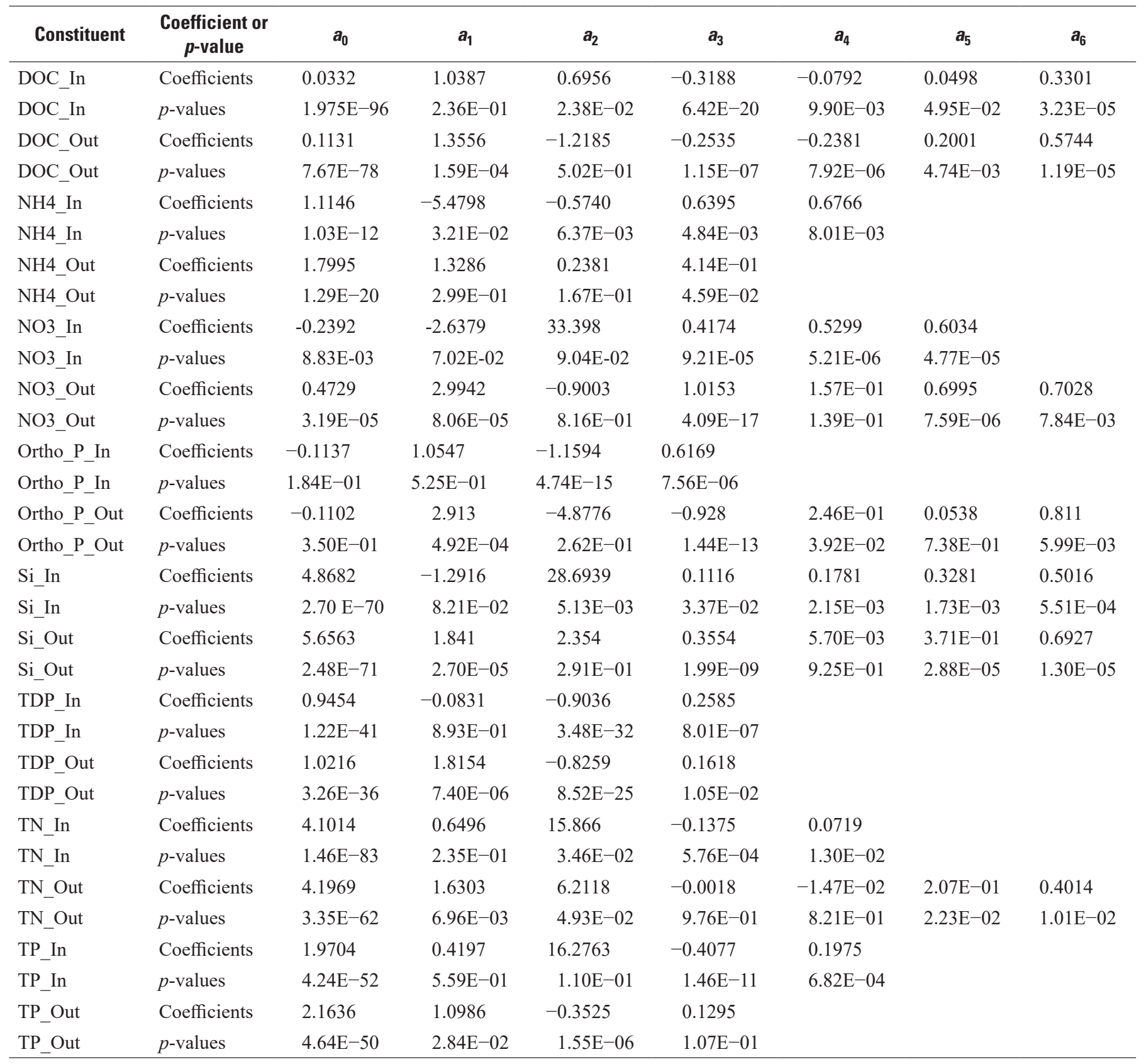

\section{Reference Cited}

Runkel, R.L., Crawford, C.G., and Cohn, T.A., 2004, Load Estimator (LOADEST) - A FORTRAN program for estimating constituent loads in streams and rivers: U.S. Geological Survey Techniques and Methods, book 4, chap. A5, 69 p., accessed June 1, 2018, at https://pubs.er.usgs.gov/publication/tm4A5. 

For more information about this report, contact: Director, New England Water Science Center U.S. Geological Survey 10 Bearfoot Road Northborough, MA 01532 dc_nweng@usgs.gov or visit our website at https://www.usgs.gov/centers/new-england-water

Publishing support provided by the

Pembroke and Lafayette Publishing Service Centers 


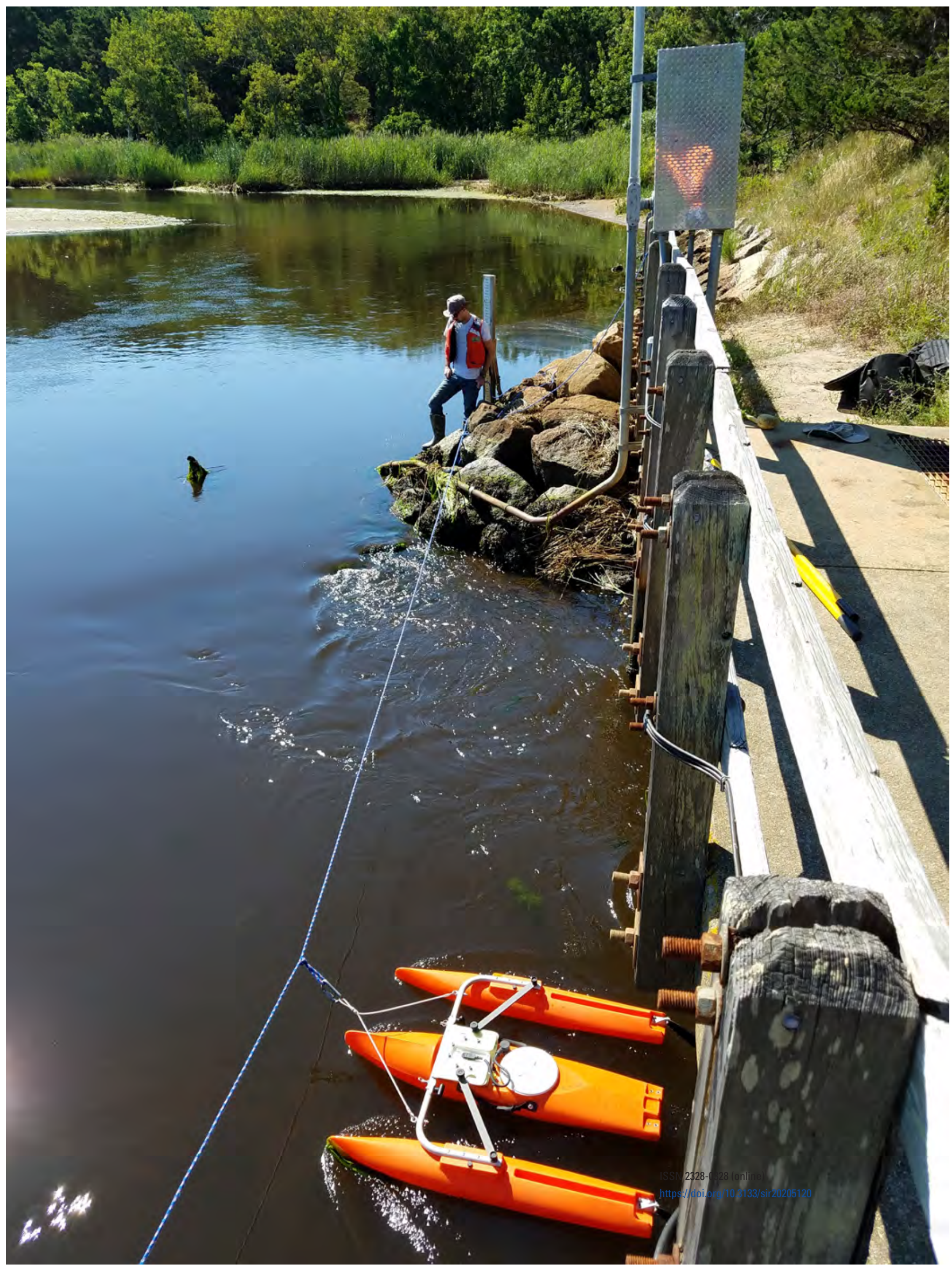

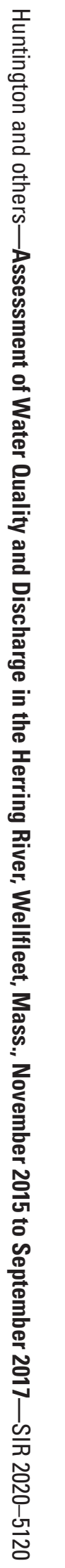

